$21619195(2)$
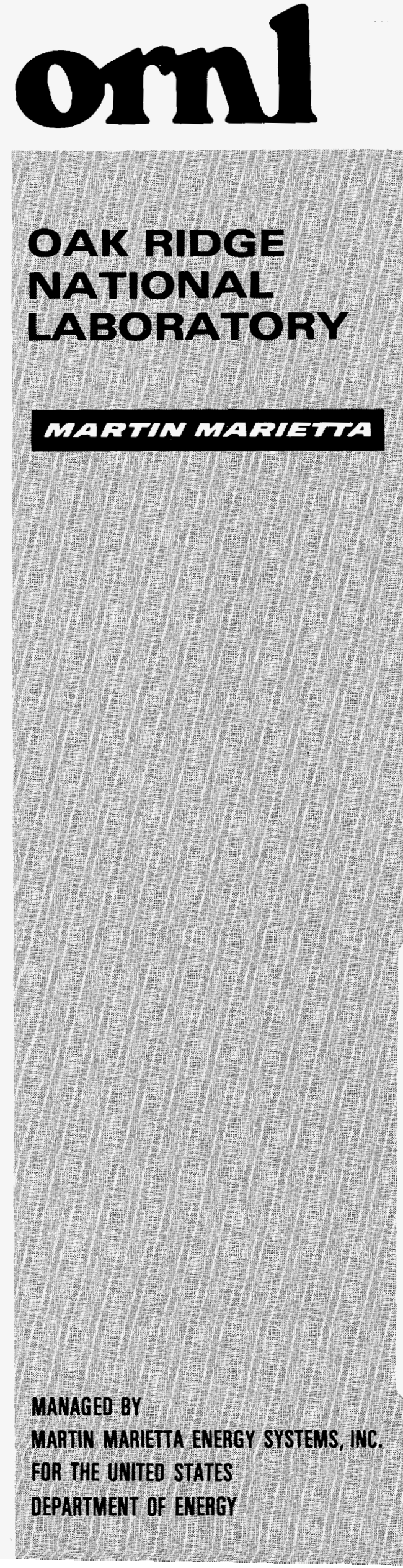

MANAGED BY

MARTIN MARIETTA ENERGY SYSTEMS, WC.

FOR THE UNITEO STATES

DEPARTMENT OF ENEAGY

\title{
Measurements for the JASPER Program Axial Shield Experiment
}

\author{
F. J. Muckenthaler \\ R. R. Spencer \\ H. T. Hunter \\ A. Shono \\ K. Chatani
}

\section{MASTER}


This report has been reproduced directly from the best available copy.

Available to DOE and DOE contractors from the Office of Scientific and Technical information, P.O. Box 62, Oak Ridge, TN 37831; prices available from (615) 576-8401, FTS 626-8401.

This report was prepared as an account of work sponsored by an agency of the United States Government. Neither the United States Government nor any agency thereof, nor any of their employees, makes any warranty, express or implied, or assumes any legal liability or responsibility for the accuracy, completeness, or usefulness of any information, apparatus, product, or process disclosed, or represents that its use would not infringe privately owned rights. Reference herein to any specific commercial product, process, or service by trade name, trademark, manufacturer, or otherwise, does not necessarily constitute or imply its endorsement, recommendation, or favoring by the United States Government or any agency thereof. The views and opinions of authors expressed herein do not necessarily state or reflect those of the United States Government or any agency thereof. 
ORNL/TM-11839

Distribution Category

UC-534

\title{
Engineering Physics and Mathematics Division \\ MEASUREMENTS FOR THE JASPER PROGRAM \\ AXIAL SHIELD EXPERIMENT
}

\author{
F. J. Muckenthaler \\ R. R. Spencer \\ H. T. Hunter \\ A. Shono* \\ K. Chatani
}

DATE PUBLISHED: AUGUST 1991

Oak Ridge National Laboratory

Oak Ridge, Tennessee 37831-6363

Prepared for the

U.S. DOE Office of

Liquid Metal Converter Reactor

*Japan Power Reactor and Nuclear Fuel Development Corporation

Prepared by the

OAK RIDGE NATIONAL LABORATORY

Oak Ridge, Tennessee 37831

managed by

MARTIN MARIETTA ENERGY SYSTEMS, INC.

for the

U.S. Department of Energy

under contract DE-AC05-84OR21400 



\section{TABLE OF CONTENTS}

\section{Page}

List of Tables $\ldots \ldots \ldots \ldots \ldots \ldots \ldots \ldots \ldots \ldots \ldots \ldots \ldots \ldots$

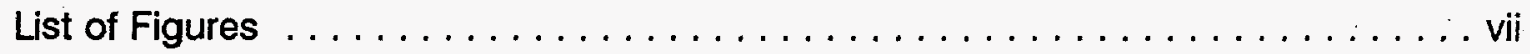

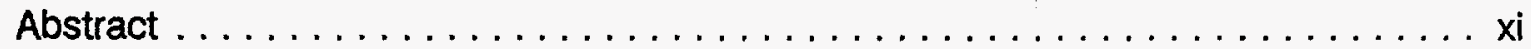

1. Introduction $\ldots \ldots \ldots \ldots \ldots \ldots \ldots \ldots \ldots \ldots \ldots \ldots \ldots \ldots \ldots$

2. Instrumentation $\ldots \ldots \ldots \ldots \ldots \ldots \ldots \ldots \ldots \ldots \ldots \ldots \ldots \ldots$

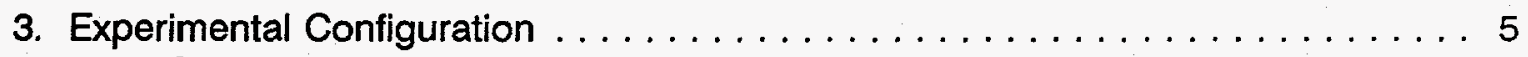

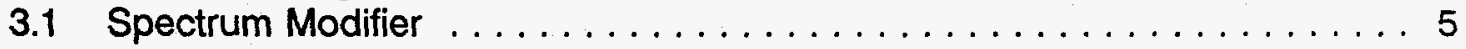

3.2 Stainless Steel Homogeneous Hexagon Assembly . . . . . . . . . . . . 6

3.3 Boron Carbide Homogeneous Hexagon Assembly . . . . . . . . . . . . 7

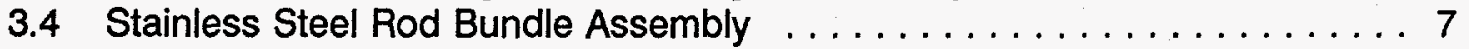

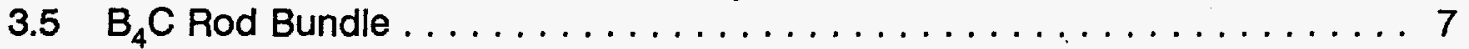

3.6 Stainless Steel Central Sodium Channel Assembly . . . . . . . . . . . . 8

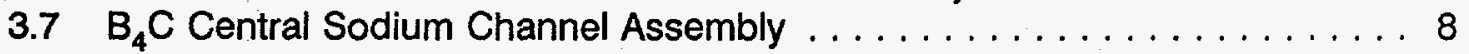

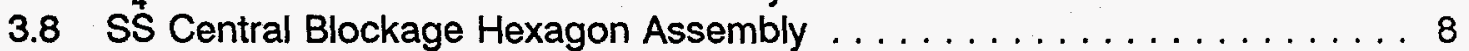

$3.9 \quad \mathrm{~B}_{4} \mathrm{C}$ Central Blockage Hexagon Assembly $\ldots \ldots \ldots \ldots \ldots \ldots \ldots \ldots$

3.10 Heterogeneous Fission Gas Plenum . . . . . . . . . . . . . . 8

3.11 Support Structure for the Assembly Mockups . . . . . . . . . . . . . . 9

3.12 Background Shield . . . . . . . . . . . . . . . . . . . 9

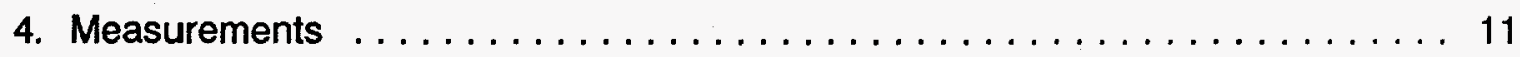

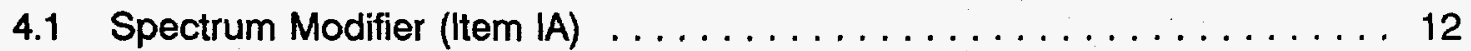

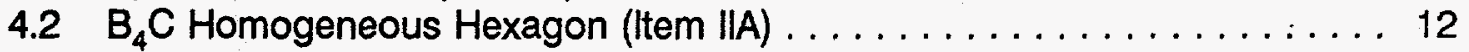

4.3 SS Homogeneous Shield Mockup (Item IIB) . . . . . . . . . . . . . 13

4.4 $\mathrm{B}_{4} \mathrm{C}$ Central Blockage $+\mathrm{B}_{4} \mathrm{C}$ Homogeneous Assemblies (Item IIIA) . . . 14

$4.5 \quad \mathrm{~B}_{4} \mathrm{C}$ Central-Blockage-Type Assemblies (Item IIIB) $\ldots \ldots \ldots \ldots \ldots \ldots \ldots 14$

4.6 SS Central Blockage Assembly + six SS Homogeneous-Type

Assemblies (Item IIIC) . . . . . . . . . . . . . . . . . . . . . 14

4.7 SS Central-Blockage-Type Assemblies (Item IIID) . . . . . . . . . . . . . 14

4.8 Fission Gas Plenum + the seven $\mathrm{B}_{4} \mathrm{C}$ Central-Blockage-Type

Assemblies (Item IIIE) . . . . . . . . . . . . . . . . . . . . . 15

$4.9 \mathrm{~B}_{4} \mathrm{C}$ Rod Bundle $+\mathrm{B}_{4} \mathrm{C}$ Homogeneous-Type Assemblies (Item IVA) . . . 15

4.10 SS Rod Bundle + SS Homogeneous-Type Assemblies (Item IVB) . . . . 15

4.11 $\mathrm{B}_{4} \mathrm{C}$ Central Sodium Channel Assembly $+\mathrm{B}_{4} \mathrm{C}$ Homogeneous-Type Assemblies (Item VA) . . . . . . . . . . . . . . . . . 16

4.12 SS Central Sodium Channel Assembly + six Homogeneous-Type Assemblies (Item VB) . . . . . . . . . . . . . . . 16

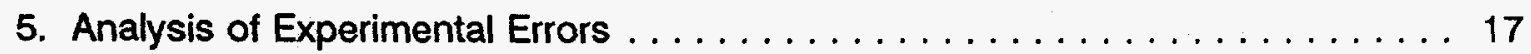


Appendix A. Experimental Program Plan for the JASPER Axial Shield

Appendix B. Tables of Data 


\section{DISCLAIMER}

Portions of this document may be illegible in electronic image products. Images are produced from the best available original document. 


\section{LIST OF TABLES}

Page

Table 1. Analysis of iron slabs $(\rho=7.86 \mathrm{~g} / \mathrm{cc})$ used in spectrum modifier ............................. 29

Table 2. Analysis of aluminum $6061(\rho=2.70 \mathrm{~g} / \mathrm{cc}) \ldots \ldots \ldots \ldots$

Table 3. Composition of boral slabs used in spectrum modifier . . . . . . . 30

Table 4. Composition of $\mathrm{UO}_{2}$ radial blanket $\ldots \ldots \ldots \ldots \ldots \ldots \ldots$

Table 5. Analysis of aluminum used in $\mathrm{UO}_{2}$ radial blanket cladding $\ldots \ldots \ldots 32$

Table 6. Composition of lithiated-paraffin bricks $(\rho=1.15 \mathrm{~g} / \mathrm{cc}) \ldots \ldots \ldots 32$

Table 7. Composition of the small concrete blocks on each side of the spectrum modifier

Table 8. Analysis of type 304 stainless steel $\ldots \ldots \ldots \ldots \ldots \ldots \ldots \ldots$

Table 9. Analysis of $B_{4} C$ in hexagon assemblies $\ldots \ldots \ldots \ldots \ldots \ldots$

Table 10. Analysis of $304 \mathrm{SS}$ in tubes used for $\mathrm{B}_{4} \mathrm{C}$ rod bundle $\ldots \ldots \ldots \ldots$

Table 11. Analysis of type 304 stainless steel sheets used in the

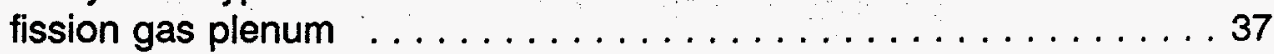

Table 12. Analysis of (6061-T6) aluminum sheets used in the fission gas plenum $(p=2.70 . \mathrm{g} / \mathrm{cc}) \ldots \ldots \ldots \ldots \ldots \ldots \ldots \ldots \ldots \ldots$

Table 12A. Analysis of lead slab used as part of mockup in IIA, B . . . . . . 39

Table 13. Analysis of concrete slab used to contain the fission

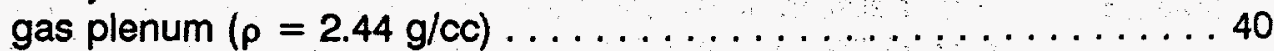

Table 14. Analysis of concrete in axial shield concrete slab . . . . . . . 41

Table 15. Fast neutron fluxes (>0.8 MeV) on centerline at $179.1 \mathrm{~cm}$ behind the radial blanket (Item IA): Run 7888A

Table 16. Neutron fluxes (50 keV to $1.4 \mathrm{MeV}$ ) on centerline at $179.1 \mathrm{~cm}$ behind the radial blanket (Item IA): Runs 1561D, 1561A, 1560A . . . 43

Table 17. Bonner ball measurements on centerline at NE-213 location

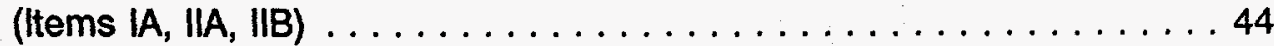


Table 18. Bonner ball measurements on centerline at $30 \mathrm{~cm}$ behind a series of configurations (Items IA, IIA-B, IIIA-E, IVA-B, VA-B) . . . . 45

Table 19. Bonner ball measurements on centerline at $150 \mathrm{~cm}$ behind a series of configurations (Items IA, IIA-B, IIA-E, IVA-B, VA-B) $\ldots \ldots \ldots 46$

Table 20. 3-Inch Bonner ball horizontal traverses through midplane at $30 \mathrm{~cm}$ behind a series of configurations (Items IA, $\| A-B$, IIIA-E, IVA-B, VA-B)

Table 21. 5-Inch Bonner ball horizontal traverses through midplane at $30 \mathrm{~cm}$ behind a series of configurations (Items IA, IIA-B, IIIA-E, IVA-B, VA-B)

Table 22. 8-Inch Bonner ball horizontal traverses through midplane at $30 \mathrm{~cm}$ behind a series of configurations (Items IA, IIA-B, IIIA-E, IVA-B, VA-B)

Table 23. Fast neutron fluxes (>0.8 MeV) on centerline at $25 \mathrm{~cm}$ behind the lead slab (32.6 cm behind axial shield). (Item IIA). Run 7895.5

Table 24. Neutron fluxes ( $50 \mathrm{keV}$ to $1.4 \mathrm{MeV}$ ) on centerline at $25 \mathrm{~cm}$ behind lead slab $(32.6 \mathrm{~cm}$ behind axial shield ). (Item IIA) . . . . . 54

Table 25. Hornyak button traverses through horizontal midplane behind a series of configurations (Items IIA-B, IIIA-E, IVA-B, VA-B) . . . . . 55

Table 26. Fast neutron fluxes (>0.8 Mev) on centerline at $98.3 \mathrm{~cm}$ behind

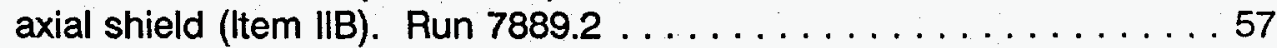

Table 27. Neutron fluxes (50 keV to $1.4 \mathrm{MeV}$ ) on centerline at $98.3 \mathrm{~cm}$ behind axial shield (Item IIB). Runs 1563, 1564A, 1564B . . . . . . . 58

Table 28. Fast neutron fluxes (>0.8 MeV) on centerline at $25 \mathrm{~cm}$ beyond lead $(36.2 \mathrm{~cm}$ behind axial shield). (Item IIB). Run $7892.3 \ldots \ldots . .59$

Table 29. Neutron fluxes ( $50 \mathrm{keV}$ to $1.4 \mathrm{MeV}$ ) on centerline at $25 \mathrm{~cm}$ beyond lead ( $36.2 \mathrm{~cm}$ behind axial shield). (Item $\| B$ ). Runs 1567A, B, C 60 


\section{UST OF FIGURES}

Figure 1. Schematic of SM-1 (Fe + Al + boral + radial blanket) (Item IA).

Note: Lithiated paraffin covers lateral sides of the configuration ....................... 63

Figure 2. Schematic of radial blanket slab containing $\mathrm{UO}_{2} \ldots \ldots \ldots$

Figure 3. Schematic of the SS homogeneous-type assembly $\ldots \ldots \ldots \ldots$

Figure 4. Schematic of the $B_{4} C$ homogeneous-type assembly $\ldots \ldots \ldots 6$

Figure 5. Schematic of the $S$ s rod bundle assembly (37 rods) $\ldots \ldots \ldots 6$

Figure 6. Schematic of the $B_{4} \mathrm{C}$ rod bundle assembly $(37$ rods) $\ldots \ldots \ldots$

Figure 7. Schematic of the SS central Na channel $\ldots \ldots \ldots \ldots \ldots \ldots$

Figure 8. Schematic of the $\mathrm{B}_{4} \mathrm{C}$ central $\mathrm{Na}$ channel $\ldots \ldots \ldots \ldots \ldots \ldots$

Figure 9. Schematic of the SS central blockage hexagon assembly $\ldots \ldots \ldots 68$

Figure 10. Schematic of the $B_{4} C$ central blockage hexagon assembly $\ldots \ldots 68$

Figure 11. Schematic of the heterogeneous fission gas plenum . . . . . . . 69

Figure 12. Schematic of the aluminum honeycomb within a concrete slab $\ldots \ldots 70$

Figure 13. Schematic of aluminum mesh dimensions along with those for the surrounding $\mathrm{B}_{4} \mathrm{C}$ collar $\ldots \ldots \ldots \ldots \ldots \ldots \ldots \ldots$

Figure 14. A photograph of a typical axial shield mockup $\ldots \ldots \ldots \ldots \ldots$

Figure 15. Lithiated paraffin background shield (shaded area) for the Axial Shield experiment . . . . . . . . . . . . . . . . 73

Figure 16. Spectrum of high-energy neutrons ( $>0.8 \mathrm{MeV})$ on centerline $179.1 \mathrm{~cm}$ beyond radial blanket (Item IA). Run $7878 \ldots \ldots \ldots 74$

Figure 17. Neutron spectrum (50 keV to $1.4 \mathrm{MeV}$ ) on centerline $179.1 \mathrm{~cm}$ beyond spectrum modifier (Item IA). Runs 1554A, 1554D, 1555B . . 75

Figure 18. Schematic of the axial shield mockup plus lead slab (Items IIA, B). Note: Lithiated paraffin covers lateral sides of the SM . . . . . . . 76 
Figure 19. Spectrum of high-energy neutrons $(>0.8 \mathrm{MeV})$ on centerline at $25 \mathrm{~cm}$ behind the lead $\left(32.6 \mathrm{~cm}\right.$ behind $\mathrm{B}_{4} \mathrm{C}$ homogeneous shield mockup) (Item IIA). Run $7895.5 \ldots \ldots \ldots \ldots \ldots \ldots \ldots 77$

Figure 20. Neutron spectrum ( $50 \mathrm{keV}$ to $1.4 \mathrm{MeV}$ ) on centerline $25 \mathrm{~cm}$ beyond the lead $\left(32.6 \mathrm{~cm}\right.$ behind $\mathrm{B}_{4} \mathrm{C}$ homogeneous shield mockup) (Item IIA). Runs 1568A, 1568B, 1570B . . . . . . . . 78

Figure 21. Schematic of the axial shield configuration (Items IIA, IIB, III, IV, V). Note: Lithiated paraffin covers lateral sides of SM . . . . . . 79

Figure 22. Radial traverse $2.37 \mathrm{~cm}$ behind the $\mathrm{B}_{4} \mathrm{C}$ homogeneous hexagon mockup using the Hornyak button (Item IIA)

Figure 23. Spectrum of high-energy neutrons (>0.8 MeV) on centerline $98.3 \mathrm{~cm}$ beyond the SS homogeneous shield mockup (Item IIB). Run 7889.2

Figure 24. Neutron spectrum (50 keV to $1.4 \mathrm{MeV}$ ) on centerline $98.3 \mathrm{~cm}$ beyond the SS homogeneous shield mockup (Item IIB).

Runs 1563, 1564A, 1564B

Figure 25. Radial traverse $2.37 \mathrm{~cm}$ behind the $\mathrm{SS}$ homogeneous shield mockup using the Hornyak button (Item IIB) $\ldots \ldots \ldots \ldots \ldots . . .83$

Figure 26. Spectrum of high-energy neutrons $(>0.8 \mathrm{MeV})$ on centerline $25 \mathrm{~cm}$ beyond lead $(36.2 \mathrm{~cm}$ beyond SS homogeneous shield

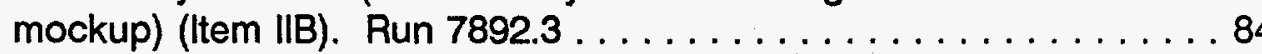

Figure 27. Neutron spectrum ( $50 \mathrm{keV}$ to $1.4 \mathrm{MeV}$ ) on centerline at $25 \mathrm{~cm}$ beyond lead ( $36.2 \mathrm{~cm}$ behind SS homogeneous shield mockup) (Item IIB). Runs 1567A, 1567B, 1567C . . . . . . . . . . . . . 85

Figure 28. Radial traverse $2.37 \mathrm{~cm}$ behind the $\mathrm{B}_{4} \mathrm{C}$ central blockage + $6 \mathrm{~B}_{4} \mathrm{C}$ homogeneous mockup using the Hornyak button (Item IIIA) . ............................ 86

Figure 29. Radial traverse $2.37 \mathrm{~cm}$ behind the $\mathrm{B}_{4} \mathrm{C}$ central blockage type shield mockup using the Hornyak button (Item IIIB) $\ldots \ldots \ldots 87$

Figure 30. Radial traverse $2.37 \mathrm{~cm}$ behind the SS central blockage $+6 \mathrm{SS}$ homogeneous-type shield mockup using the Hornyak button (Item IIIC) . . . . . . . . . . . . . . . . . . . . . 88

Figure 31. Radial traverse $2.37 \mathrm{~cm}$ behind the $\mathrm{SS}$ central blockage type shield mockup using the Hornyak button (Item IIID) . . . . . . . . . 89 
Figure 32. Schematic of the fission gas plenum $+7 \mathrm{~B}_{4} \mathrm{C}$ central blockage type shield mockup (Item IIIE). Note: Lithiated paraffin covers lateral sides of the SM configuration

Figure 33. Radial traverse $1.85 \mathrm{~cm}$ behind the fission gas plenum + $7 \mathrm{~B}_{4} \mathrm{C}$ central blockage type shield mockup using the Hornyak button (Item IIIE)

Figure 34. Radial traverse $2.37 \mathrm{~cm}$ behind the $\mathrm{B}_{4} \mathrm{C}$ rod bundle $+6 \mathrm{~B}_{4} \mathrm{C}$ homogeneous-type shield mockup using the Hornyak button (Item IVA)

Figure 35. Radial traverse $2.37 \mathrm{~cm}$ behind the SS rod bundle $+6 \mathrm{SS}$ homogeneous-type shield mockup using the Hornyak button (Item IVB)

Figure 36. Radial traverse $2.37 \mathrm{~cm}$ behind the $\mathrm{B}_{4} \mathrm{C}$ central sodium channel shield mockup using the Hornyak button (Item VA)

Figure 37. Radial traverse $2.37 \mathrm{~cm}$ behind the $S S$ central sodium channel shield mockup using the Hornyak button (Item VB) 95 

The Axial Shield Experiment was conducted at the Oak Ridge National Laboratory (ORNL) during 1990-1991 as part of a continuing series of eight experiments planned for the Japanese-American Shielding Program for Experimental Research (JASPER) program starting in 1986. The program is intended to provide support for the development of current designs proposed for advanced liquid metal reactor (LMR) systems both in Japan and the United States. As in the previous two experiments, the same spectrum modifier was used to alter the Tower Shielding Reactor source spectrum to one representing the LMR neutron spectra directly above the core in the area of the fission-gas plenum. In one of the measurements the spectrum was further modified by the fission gas plenum. In all cases the modified spectrum was followed by combinations of seven hexagon assemblies that represented different coolant flow and shielding patterns within the assemblies. The varied configuration permitted not only a study of the different designs, but also allowed a comparison to be made of the relative neutron attenuation effectiveness of boron carbide and stainless steel in such designs.

This experiment was the third in a series of eight experiments to be performed as part of a cooperative effort between the United States Department of Energy (U.S. DOE) and the Japan Power Reactor and Nuclear Fuel Development Corporation (PNC). This experiment, as was the previous Radial Shield Attenuation and Fission Gas Plenum Experiments, intended to provide support for the development of advanced sodium-cooled reactors. 


\section{INTRODUCTION}

In August 1990, the JASPER program was restarted at the Tower Shielding Facility (TSF) after a delay of three years. This phase of the program, called the Axial Shield Experiment, is the third in a series of eight planned experiments. The previous two were preceded by the Radial Shield Attenuation and the Fission Gas Plenum Experiments completed during 1986-1987. All eight experiments were planned jointly by ORNL, participant for U.S. DOE, and the PNC.

The Axial Shield Experiment was designed to extend the studies of the effectiveness of different axial shield designs beyond the fission gas plenum and at the same time provide a comparison of the neutron attenuation characteristic of stainless steel and boron carbide as they are integrated into the designs. The experiment serves not only to provide data for verification of the analytical tools used in calculating the neutron streaming in each design, but also to provide a basis for determining the effectiveness of these materials in a given shield design. The results should prove to be beneficial in the design of the overall reactor vessel system.

The same spectrum modifier of iron, aluminum, boral, followed by a radial blanket comprised of natural uranium, aluminum, and sodium that was used in the previous Radial Shield and Fission Gas Plenum Experiments, provided the neutron spectrum incident on the axial shield. The configurations to be studied included hexagons containing three different internal geometrical designs whose components comprised two different materials for study. The designs consisted of: (1) a central blockage type in which the coolant flowed around a central shield plug; (2) a rod bundle type in which the shield material was in the form of small rods spaced for coolant flow; and (3) an annular type in which the coolant flowed centrally through the fuel assembly. The shield materials of interest were boron carbide and stainless steel.

Each mockup to be studied was in the form of a central hexagon surrounded by six hexagons of a selected internal design. The seven assemblies were contained in a $45-\mathrm{cm}$-long aluminum honeycomb that was surrounded radially by several $\mathrm{cm}$ of boron carbide, all of which were contained in a large concrete slab.

The experimental configurations were positioned in the horizontal beam emerging from the reactor shield collimator, preceded by the spectrum modifier. 
Configuration changes were made by the removal from and the insertion of these various hexagon assemblies into the aluminum honeycomb, with measurements made behind each mockup according to the program plan given in Appendix $A$. 


\section{INSTRUMENTATION}

The Bonner ball detection system used at the Tower Shielding Facility (TSF) consists of a series of different-sized polyethylene balls, each of which measures an integral of the neutron flux weighted by the energy-dependent response function for that ball. The detection device inside the ball consisted of a $5.1-\mathrm{cm}$-diam spherical proportional counter filled with $\mathrm{BF}_{3}$ gas $\left({ }^{10} \mathrm{~B} / \mathrm{B}\right.$ concentration $\left.=0.96\right)$ to a pressure of 0.5 atmospheres. In order to cover a range of neutron energies, the counter was used bare, covered with cadmium, or enclosed in various thicknesses of polyethylene shells surrounded by cadmium, each detector being identified by the diameter of the polyethylene sphere. Data from the Bonner ball measurements are predicted analytically by folding a calculated neutron spectrum with the Bonner ball response functions determined by Maerker et al. ${ }^{1}$ and C. E. Burgart et al. ${ }^{2}$

An NE-213 liquid scintillator spectrometer system measured the neutron spectrum from about $800 \mathrm{keV}$ to $15 \mathrm{MeV}$. This system makes use of pulse-shape discrimination to distinguish neutron pulses from gamma ray pulses. The resulting neutron pulse-height data obtained with the spectrometer were unfolded with the FERD code ${ }^{3}$ to yield absolute neutron energy spectra.

Spherical proton-recoil counters, filled with hydrogen to pressures of 1,3 , and 10 atmospheres, covered the neutron energy range from about $50 \mathrm{keV}$ to $1 \mathrm{MeV}$. Pulse-height data from the counters were unfolded with the SPEC-4 code, ${ }^{4}$ which makes use of the unfolded NE-213 spectrum to correct for the contribution from higher-energy neutrons.

The Hornyak button detector consisted of a $0.635-\mathrm{cm}$-diam, $0.159-\mathrm{cm}$-thick button of lucite interspersed with zinc sulfide mounted on a photomultiplier tube. The calibration procedure was based on first exposing the scintillator to a $2 \mathrm{R} / \mathrm{h}$ gammaray dose rate and adjusting the amplifier gain so that a prescribed count rate was obtained at a pulse height setting (PHS) of 0.06 volts. This procedure kept the gain of the system constant on a daily basis. The button was then exposed to a known strength ${ }^{252} \mathrm{Cf}$ neutron source and a dose rate/count rate ratio obtained. However, for this particular experiment, it was necessary to obtain this neutron dose rate ratio at a higher PHS, namely 3.5 volts, to guard against a gamma ray contribution to the count 
rate when run in gamma ray fields greater than $2 \mathrm{R} / \mathrm{h}$. Thus, even though the detector response no longer corresponds to that of a dosimeter, it was elected to continue expressing the measurements in terms of a dose rate. At that PHS, even though the lower limit of the neutron energy response for the button is not known it did not detract from its usage to define the neutron streaming effect where small gaps existed in the mockup structure.

The measurements for each detector were referenced to the reactor power (watts) using the data from two fission chambers positioned along the reactor centerline as a basis. The response of these chambers as a function of reactor power level was established previously through several calorimetric measurements of the heat generated in the reactor during a temperature equilibrium condition (heat power run). 


\section{EXPERIMENTAL CONFIGURATION}

The experimental program plan (see Appendix A) specified that neutron measurements be made behind a series of mockups, each containing a group of seven hexagonal assemblies whose internal designs could be altered to provide three different approaches to studying their neutron attenuation effectiveness in combination with liquid coolant flow. The mockups were to represent LMR shield designs currently under study for the area directly above the reactor core and fission gas plenum. These designs are: (1) a central blockage type in which the coolant flows around a central cylinder of either boron carbide or stainless steel; (2) a rod bundle type in which the coolant flows between a bundle of small shield tubes composed of either boron carbide or stainless steel; and (3) a reverse of (1) where now the coolant flows centrally through the shield materials.

The neutron source for this series of measurements was the Tower Shielding Reactor II (TSR-II) where the emergent spectrum was modified to be similar to that predicted for the LMR design. It should be noted that the material thicknesses mentioned in the program plan are nominal, the actual thicknesses used are given in the left corner of the slabs shown in the various figures displayed throughout the report.

\subsection{SPECTRUM MODIFIER}

The preanalysis calculation indicated that nominally. $10 \mathrm{~cm}$ of iron, followed by $10 \mathrm{~cm}$ of aluminum, $2.5 \mathrm{~cm}$ of boral, and $20.3 \mathrm{~cm}$ of "radial blanket" placed in the TSR-Il beam would provide a spectrum of neutrons representative of those incident on the axial shield for the LMR core. In the experiment (see Figure 1) the iron component consisted of two rectangular slabs 5.16- and $5.11-\mathrm{cm}$-thick, both $152.4 \mathrm{~cm}(60-\mathrm{in})$ on an edge. The three aluminum slabs totalled $9.17 \mathrm{~cm}$ in thickness, and the boral was 2.54-cm-thick, all having the same edge length as the iron slabs. Compositions of the iron, aluminum, and boral are given in Tables 1, 2, and 3 respectively. (Note: All tables are included in Appendix B).

The $\mathrm{UO}_{2}$ slabs used to represent the "radial blanket" were fabricated for earlier experiments performed in the Liquid Metal Fast Breeder Reactor (LMFBR) program. They contained natural $\mathrm{UO}_{2}$ pellets, $1.397-\mathrm{cm}$ outside diameter (OD), enclosed in 
1.524-cm OD aluminum cylinders. Between the aluminum and the pellets was a $0.00508-$ to $0.01016-\mathrm{cm}$ annulus filled with argon. The cylinders were stacked side-by-side vertically having a triangular pitch of $1.608 \mathrm{~cm}$. The space between the aluminum cylinders was filled with sodium. This arrangement of the rods and sodium was enclosed in an iron vessel having an overall thickness of $11.05 \mathrm{~cm}$ and a length of $152.4 \mathrm{~cm}$ on each side.

Each of the two radial blanket slabs used in this modifier contained 522 rods of natural uranium amounting to $64.6 \%$ of the volume of the slab. The rods were divided into seven rows, with alternating rows of 74 and 75 rods. The $\mathrm{UO}_{2}$ density was $10.28 \mathrm{~g} / \mathrm{cc}$ (94\% of theoretical). The volume fraction of the aluminum cladding was $11.2 \%$ while that for the sodium and argon are $23.3 \%$ and about $1 \%$ respectively. The pellet stack length in each of the rods was approximately $121.9 \mathrm{~cm}$. These rods were built by Numes Corporation in 1962 to conform, in general, to the then AEC/RDT design standards for the Fast Flux Test Facility (FFTF). A schematic of the slab is shown in Figure 2, with analyses of the $\mathrm{UO}_{2}$ and aluminum given in Tables 4 and 5.

This spectrum modifier (SM1) was surrounded by $20.3 \mathrm{~cm}$ (8-in) of lithiated paraffin followed by up to $152.4 \mathrm{~cm}(60-\mathrm{in})$ of concrete to minimize the neutrons scattering back into the slabs and to reduce the amount of background radiation reaching the detectors. The lithiated paraffin was shaped as small bricks $10.16 \mathrm{~cm}$ on edge and $20.3 \mathrm{~cm}$ long (4-in-facing $\times$ 8-in-long) and the concrete consisted of blocks $30.48 \mathrm{~cm}$ long by $15.24 \mathrm{~cm}$ on edge (12-in-long $\times 6$-in-facing). The composition of the lithiated paraffin and the small concrete blocks have been presented in Tables 6 and 7 respectively.

\subsection{STAINLESS STEEL HOMOGENEOUS HEXAGON ASSEMBLY}

The homogeneous stainless steel (SS) hexagon assembly design was to have alternate pieces of SS and aluminum as shown in Figure 3. Aluminum acted as a substitute for sodium in this assembly and throughout the experiment because the cost of fabricating the sodium pieces would have been prohibitive and the neutronic properties of aluminum were very similar to those of sodium. The SS and Al pieces were 5.357 - and $2.136-\mathrm{cm}$-thick respectively, both being $15.99 \mathrm{~cm}$ from flat edge to flat edge. Six pieces of each material comprised a single hexagon, with the initial SS piece nearest the reactor. The elemental composition of the $\mathrm{Al}(6061)$ is given in 
Table 2, while that for the SS (304) is given in Table 8. It should be noted that the values quoted throughout this report for the physical dimensions of the various components used in the hexagons were average values.

\subsection{BORON CARBIDE HOMOGENEOUS HEXAGON ASSEMBLY}

The $\mathrm{B}_{4} \mathrm{C}$ homogeneous assembly was composed of alternating pieces of $\mathrm{B}_{4} \mathrm{C}$ and SS, a schematic of which is shown in Figure 4. The $\mathrm{B}_{4} \mathrm{C}$ was contained in an aluminum vessel, the internal depth of the $\mathrm{B}_{4} \mathrm{C}$ powder being $7.77 \mathrm{~cm}$. The width of the $\mathrm{B}_{4} \mathrm{C}$ was $14.73 \mathrm{~cm}$ from inside flat surface to inside flat surface with a wall thickness of $0.627 \mathrm{~cm}$, making the outside dimensions of the container $15.98 \mathrm{~cm}$. Each end plate thickness covering the $\mathrm{B}_{4} \mathrm{C}$ was $1.123 \mathrm{~cm}$. The density of the $\mathrm{B}_{4} \mathrm{C}$ powder (120 grit) was $1.41 \mathrm{~g} / \mathrm{cc}$. An analysis of the $\mathrm{B}_{4} \mathrm{C}$ powder is given in Table 9 . The thickness of the SS pieces was $1.25 \mathrm{~cm}$. When the hexagon was placed in the configuration an aluminum-enclosed $\mathrm{B}_{4} \mathrm{C}$-loaded container was placed nearest the reactor, followed by alternating pieces of SS and aluminum clad $\mathrm{B}_{4} \mathrm{C}$.

\subsection{STAINLESS STEEL ROD BUNDLE ASSEMBLY}

This single assembly had a series of 37 rods of 304 SS equally spaced in aluminum that was surrounded by a $0.452-\mathrm{cm}$-thick wrapper of SS as seen in Figure 5 . The rods had a diameter of $2.041 \mathrm{~cm}$ and were separated on a pitch of $2.38 \mathrm{~cm}$. The aluminum housing was $15.00 \mathrm{~cm}$ from flat surface to flat surface.

\section{5 $\mathrm{B}_{4} \mathrm{C}$ ROD BUNDLE}

The design of the $\mathrm{B}_{4} \mathrm{C}$ rod bundle assembly was identical to the SS rod bundle except for the rods. The rods in this assembly consisted of SS tubes filled with $B_{4} C$ (120 grit powder analyzed in Table 9). The OD of the tubing was $2.06 \mathrm{~cm}$, its inside diameter (ID) $1.897 \mathrm{~cm}$, with each tube having a wall thickness of $0.0813 \mathrm{~cm}$. The cap thickness on each end of the tube was $0.159 \mathrm{~cm}$. The length of the $\mathrm{B}_{4} \mathrm{C}$ inside each tube was $44.7 \mathrm{~cm}$, giving a volume of $126.28 \mathrm{cc}$. The average density of the $B_{4} C$ in the 37 rods was $1.30 \mathrm{~g} / \mathrm{cc}$. These rods were also spaced on a pitch of $2.38 \mathrm{~cm}$. The average width of the aluminum was approximately $15.00 \mathrm{~cm}$ (flat surface to flat surface), and was surrounded, in this case, by nearly $0.465 \mathrm{~cm}$ of SS as seen in Figure 6. An analysis of the SS tubes is given in Table 10. 


\subsection{STAINLESS STEEL CENTRAL SODIUM CHANNEL ASSEMBLY}

The SS central sodium channel assembly mocks up the SS axial shield design with sodium flow through the center of the assembly. In this assembly, illustrated in Figure 7, the $8.96-\mathrm{cm}$-diam aluminum cylinder again represents the sodium path ran the full length of the hexagon. The SS surrounding the cylinder had a flat surface to flat surface width of $16.03 \mathrm{~cm}$.

\subsection{B $_{4}$ C CENTRAL SODIUM CHANNEL ASSEMBLY}

This particular hexagon complements the above assembly (3.6) with $\mathrm{B}_{4} \mathrm{C}$ replacing the SS. An SS can with $0.452-\mathrm{cm}$-thick walls served as the container for the $\mathrm{B}_{4} \mathrm{C}$ as shown in Figure 8. The length of the central aluminum cylinder was only $43.412 \mathrm{~cm}$, with the two aluminum end pieces $\left(0.794 \mathrm{~cm}\right.$ thick) that enclose the $\mathrm{B}_{4} \mathrm{C}$ providing the remainder of the $45 \mathrm{~cm}$ length. The $5760.1 \mathrm{~cm}$ volume of $\mathrm{B}_{4} \mathrm{C}$ in the assembly had a density of $1.39 \mathrm{~g} / \mathrm{cc}$.

\subsection{SS CENTRAL BLOCKAGE HEXAGON ASSEMBLY}

In these assemblies the central neutron shield was represented by a $12.98-\mathrm{cm}$ diam cylinder of SS surrounded by aluminum as a substitute for sodium. The aluminum, in turn, was wrapped by plates of SS that formed the outer covering. The width of the aluminum was $15.05 \mathrm{~cm}$ (flat surface to flat surface), and the SS blanket thickness was $0.462 \mathrm{~cm}$. The arrangement of a typical assembly is given in Figure 9 .

\section{$3.9 \mathrm{~B}_{4} \mathrm{C}$ CENTRAL BLOCKAGE HEXAGON ASSEMBLY}

This assembly was a duplicate of the previous assembly with $\mathrm{B}_{4} \mathrm{C}$ powder replacing the SS cylinder (see Figure 10) while keeping the aluminum block and SS wrapper thicknesses the same. The length of the $B_{4} C$ was limited to $44.05 \mathrm{~cm}$ so that each opening of the central cylinder could be covered with a $0.476-\mathrm{cm}$-thick aluminum plate. The volume of the $B_{4} C$ was $5846.9 \mathrm{cc}$ having a density of $1.38 \mathrm{~g} / \mathrm{cc}$.

\subsection{HETEROGENEOUS FISSION GAS PLENUM}

The heterogeneous fission gas plenum used in this experiment (see Figure 11) was the same unit that was used in the previous Fission Gas Plenum experiment ${ }^{5}$. The design of this plenum was representative of an actual plenum planned for use in 
advanced LMRs. The OD of the SS tubing in the plenum was $7.93 \mathrm{~mm}$, and the tubing wall thickness was $0.508 \mathrm{~mm}$. A total of 512 tubes were used, giving volume fractions of 16,33 , and $51 \%$ for SS, sodium (aluminum), and air respectively. The plenum had a nominal thickness of $20 \mathrm{~cm}$ and was contained in a concrete slab when placed in the mockup. Analyses of the SS and aluminum sheets are given in Tables 11 and 12 respectively. An analysis of the concrete in the slab containing the plenum is in Table 13.

\subsection{SUPPORT STRUCTURE FOR THE ASSEMBLY MOCKUPS}

The shield mockup was composed of a combination of seven subassemblies placed so that the axis of the central assembly coincided with the horizontal centerline of the reactor beam as it passed through the mockups. To support these assemblies in that fashion, a 45-cm-thick aluminum honeycomb structure, shown in Figure 12, was secured in a modified concrete slab that had been used in a previous experiment. The honeycomb itself represented a vertical path for sodium flow between assemblies in a typical LMR design. Between the aluminum honeycomb and the surrounding concrete slab was a layer of $\mathrm{B}_{4} \mathrm{C}$ whose width varied as shown in Figure 13. This $\mathrm{B}_{4} \mathrm{C}$ had an average density of $1.33 \mathrm{~g} / \mathrm{cc}$. Between the $\mathrm{B}_{4} \mathrm{C}$ and the concrete was a $0.952-\mathrm{cm}$ iron envelope. The $\mathrm{B}_{4} \mathrm{C}$ was covered on both ends of the honeycomb with a $0.81-\mathrm{cm}$-thick aluminum plate, making the total length of shield in that region about $46.6 \mathrm{~cm}$ (the mesh was only $45 \mathrm{~cm}$ long). The concrete slab was $304.8 \mathrm{~cm}$ wide, $213.4 \mathrm{~cm}$ high, and $45 \mathrm{~cm}$ thick. The analysis of the concrete in the slab is contained in Table 14. A picture of a typical experimental arrangement is shown in Figure 14.

\subsection{BACKGROUND SHIELD}

It has been the custom in the past to obtain background measurements as well as foreground measurements when the detectors were located at sufficient distance behind the mockups where neutron contributions to the detector from areas other than the mockup itself might not be negligible. For these measurements a container of lithiated paraffin bricks, 36 in $\times 36$ in and 16 in thick, was usually placed between the detector and mockup in such a manner that contributions directly to the detector from the mockup would be greatly reduced. The same type of background measurements were made for each of the foreground centerline measurements obtained at $150 \mathrm{~cm}$ 
behind the mockup in this experiment, but the shape of the shadow shield was altered to match, as close as reasonably feasible, the shape of the area defined by the hexagons and $\mathrm{B}_{4} \mathrm{C}$ shroud. The analysis of the lithiated paraffin is given in Table 6 . A schematic of the background shield used for this experiment is shown in Figure 15, where it is superimposed upon the axial shield outline. Again the shield material was lithiated paraffin bricks and their outline is defined by the gray (darker) area shown. To its left is a side view of the shield thickness, the width of 5 bricks being equivalent to $50.8 \mathrm{~cm}$. The bricks were placed directly behind the axial shield, maintaining the same arrangement for all the detectors. 


\section{MEASUREMENTS}

The last procedure in the fabrication of the individual hexagon insert was the machining of the flat surfaces after each of the hexagons was assembled. This was done to try and maintain close control of the void spacings between the surfaces of the hexagons and the surfaces of the aluminum mesh. A tolerance of several mils between surfaces was requested so that the neutron streaming through the voids would be a minimum. Small errors in such tolerances could lead to problems in insertion and removal of the assemblies making it difficult to change them. To help minimize this possibility it was planned that the number of changes be limited, which led to the selection of the order in which the various phases of this experiment were performed.

The initial mockup selected was Item IIIE (see Appendix A) in which the fission gas plenum preceded the axial shield. Following these measurements the fission gas plenum was removed and the concrete slab containing the hexagons repositioned for the remainder of the measurements. The last group of hexagons to be run were the two mockups in Item II, where measurements for both of the homogeneous configurations, $B_{4} C$ and SS, were listed. Of these, measurements behind the $B_{4} C$ hexagons (Item IIA) were scheduled last because the individual pieces that compose an assembly were very difficult to remove and could require movement of the concrete slab to accomplish the feat which might lead to differences in configuration orientation. This problem did not exist for the SS homogeneous hexagons in Item IIB.

The need for the addition of the lead slab for the NE-213 measurements in Items IIA and IIB arose because the initial spectral measurements for IIB without the lead present showed a high gamma-ray-to-neutron count rate ratio up 25 to 1 . Ratios of high magnitude make it difficult to obtain neutron spectra with good statistics in a reasonable counting period since the maximum count rate for the data system is limited and most of these counts are due to gamma rays. Insertion of the lead slab reduced the ratio to 3 to 1 , which is acceptable. The data obtained without the lead in IIB, however, will be reported along with the data using lead. Since the measurements in Item IIA were made after those in Item IIB, only spectral measurements with lead were made for that group of hexagons. 
It should be noted that even though there were changes in the order in which the measurements were made, the results have been reported according to the program plan as given in Appendix A. Throughout this report the words configurations, item, and mockup will be used interchangably when referring to the contents of the program plan.

\subsection{SPECTRUM MODIFIER (ITEM IA)}

Measurements of the neutron spectra behind the spectrum modifier (SM), a schematic of which is shown in Figure 1, were made with both the NE-213 liquid scintillator and the hydrogen-filled proton recoil detectors. The detectors were placed on the reactor beam centerline at $179.1 \mathrm{~cm}$ behind the last radial blanket. The resulting energy spectra values are plotted in Figures 16 and 17 and listed in Tables 15 and 16 for the NE-213 and hydrogen counter, respectively. Integral flux measurements were made with the 3-, 5-, and 10-in Bonner balls at the same location and these results are given in Table 17.

Data were obtained along the centerline of the configuration with the 3-, 4-, 5-, 8-, 10-, and 12-in Bonner balls at $30 \mathrm{~cm}$ and $150 \mathrm{~cm}$ behind the radial blanket. Results from measurements at $30 \mathrm{~cm}$ are given in Table 18, while those at $150 \mathrm{~cm}$ are listed in Table 19. Mapping of the transverse flux distribution from south ( $S$ on data tables) to north ( $\mathrm{N}$ on data tables) at $30 \mathrm{~cm}$ behind the SM was made with the 3-, 5-, and 10-in Bonner balls along the horizontal midplane. By mistake, the 10-in BB was run instead of the 8-in ball called for in the data plan and this is so indicated in the data table. These results are listed in Tables 20,21 , and 22 , respectively.

\section{2 $\mathrm{B}_{4} \mathrm{C}$ HOMOGENEOUS HEXAGON (ITEM IIA)}

The measurements of the neutron spectrum in Item IIA required the addition of a lead slab following the mockup, as was discussed earlier (see section 4). A schematic of the mockup is shown in Figure 18. The spectrometers, NE-213 and hydrogen counters, were placed $25 \mathrm{~cm}$ behind the lead on centerline. The spectral results are listed in Tables 23 and 24, and plotted in Figures 19 and 20 respectively for the NE-213 and hydrogen counters. The 3-, 5-, and 10-in Bonner ball results at the same location are given in Table 17. An analysis of the lead slab is given in Table 12A. 
With the lead removed (see schematic in Figure 21), both the horizontal traverse and the centerline measurements were made behind the homogeneous mockup with the Bonner balls. The centerline measurements at 30 and $150 \mathrm{~cm}$ are given in Tables 18 and 19, and the horizontal measurements at $30 \mathrm{~cm}$ are listed in Tables 20,21, and 22. Results from the horizontal measurements with the Hornyak detector at $2.37 \mathrm{~cm}$ behind the mockup are shown in Table 25 and plotted in Figure 22.

\subsection{SS HOMOGENEOUS SHIELD MOCKUP (ITEM IIB)}

The equivalent homogeneous mockup for the various SS-type shield assemblies to be studied consisted of hexagon-shaped pieces of aluminum and SS placed alternately in each opening of the aluminum mesh starting with the SS piece closest to the reactor. A sketch of the hexagon as used in the experiment is shown in Figure 3, along with the dimensional information for each of the individual pieces.

Neutron spectra were obtained at $98.3 \mathrm{~cm}$ behind the axial shield with both the NE-213 and hydrogen counters. The results from these measurements are given in Tables 26 and 27, and plotted in Figures 23 and 24. The 3-, 5-, and 10-in Bonner ball measurements at the NE-213 location are given in Table 17. Horizontal traverses with the 3-, 5-, and 8-in Bonner balls were made at $30 \mathrm{~cm}$ behind the shield and these results are listed in Tables 20,21 , and 22. Results from the Hornyak button traverse at $2.37 \mathrm{~cm}$ behind the shield are given in Table 25 and plotted in Figure 25. Data from a series of Bonner ball measurements at 30 and $150 \mathrm{~cm}$ along the axis behind the mockup are presented in Tables 18 and 19.

It was noted at the time of the NE-213 measurement that the gamma-to-neutron count rate ratio was rather high, 25 to 1 . It was requested of PNC that we add some lead behind the hexagons to reduce the gamma ray contribution and repeat the spectral data. One slab, $152.4 \mathrm{~cm}$ on a side and $3.81 \mathrm{~cm}$ thick, was placed directly behind the axial shield as shown in Figure 18. The spectrometers were placed at 25 $\mathrm{cm}$ behind the lead $(32.6 \mathrm{~cm}$ from the axial shield) and the measurements repeated, this time in a gamma-to-neutron field of about 3 to 1 . The resulting NE-213 spectrum is shown in Figure 26 and listed in Table 28. Accompanying data with the hydrogen counters are listed in Table 29 with a plot of these values in Figure 27. The Bonner ball data at this same location is given in Table 17. 


\subsection{B $_{\mathbf{4}}$ C CENTRAL BLOCKAGE $+\mathrm{B}_{\mathbf{4}} \mathrm{C}$ HOMOGENEOUS ASSEMBLIES (ITEM IIIA)}

The $\mathrm{B}_{4} \mathrm{C}$ central-blockage-type assembly in this mockup (see section 3.9) was surrounded by six $B_{4} C$ homogeneous assemblies (see section 3.3 ) following the $S M$. Measurements made on centerline with the 3-, 4-, 5-, 8-, 10-, and 12-in Bonner balls at $30 \mathrm{~cm}$ and $150 \mathrm{~cm}$ behind the shield are listed in Tables 18 and 19. Data from traverses with the 3-, 5-, and 8-in Bonner ball at $30 \mathrm{~cm}$ behind the hexagons are presented in Tables 20,21, and 22. Results from the Hornyak button traverse at 2.37 $\mathrm{cm}$ behind the shield are given in Table 25 and plotted in Figure 28.

\subsection{B B $^{C}$ CENTRAL-BLOCKAGE-TYPE ASSEMBLIES (TIEM IIIB)}

For this axial shield mockup the full seven $\mathrm{B}_{4} \mathrm{C}$ central-blockage-type assemblies (see section 3.9) were used. Measurements were made on centerline at $30 \mathrm{~cm}$ and $150 \mathrm{~cm}$ behind the shield with the 3-, 4-, 5-, 8-, 10-, and 12-in Bonner balls and these data are given in Tables 18 and 19. Radial traverse results at $30 \mathrm{~cm}$ behind the mockup with the 3-, 5-, and 8-in Bonner balls are listed in Tables 20, 21, and 22. The Hornyak button traverse results at $2.37 \mathrm{~cm}$ behind the axial shield are part of Table 25, and a plot of the data occurs in Figure 29.

\subsection{SS CENTRAL BLOCKAGE ASSEMBLY + SIX SS HOMOGENEOUS-TYPE ASSEMBLIES (TEM IIIC)}

For this mockup the $\mathrm{B}_{4} \mathrm{C}$ central blockage assemblies were replaced with a single SS central blockage assembly (see section 3.8 ), surrounded by six SS homogeneous-type assemblies. Measurements on centerline with the 3-, 4-, 5-, 8-, 10, and 12-in Bonner balls at $30 \mathrm{~cm}$ and $150 \mathrm{~cm}$ behind the assemblies are given in Tables 18 and 19. Results from the radial traverse at $30 \mathrm{~cm}$ behind the mockup are listed in Tables 20, 21, and 22. The results from the Hornyak button radial traverse are part of Table 25. A plot of the data is shown in Figure 30.

\subsection{SS CENTRAL-BLOCKAGE-TYPE ASSEMBLIES (TIEM IIID)}

The axial shield in this mockup comprised the seven SS central-blockage-type assemblies. Results from the radial traverses at $30 \mathrm{~cm}$ behind them with the 3-, 5-, and 8-in Bonner balls are listed in Table 20,21, and 22. The six Bonner ball measurements on centerline at $30 \mathrm{~cm}$ and $150 \mathrm{~cm}$ behind the shield are shown in 
Tables 18 and 19. The Hornyak button traverse measurements are included in Table 25 and plotted in Figure 31.

\subsection{FISSION GAS PLENUM + THE SEVEN B ${ }_{4}$ C CENTRAL-BLOCKAGE-TYPE ASSEMBLIES (ITEM IIIE)}

In this mockup the 20 -cm-thick fission gas plenum assembly, described in section 3.10, was placed between the SM and the axial shield that consisted of the seven $\mathrm{B}_{4} \mathrm{C}$ central-blockage-type assemblies. The physical arrangement is shown in

Figure 32. Results from the radial traverses with the 3-, 5-, and 8-in Bonner balls at 30 $\mathrm{cm}$ are given in Tables 20,21 , and 22. The centerline traverse measurements at 30 $\mathrm{cm}$ and $150 \mathrm{~cm}$ are listed in Tables 18 and 19. Radial traverse data with two different Hornyak button detectors are included in Table 25. For this mockup only, the data was obtained at $1.85 \mathrm{~cm}$ behind the axial shield, whereas, for the remainder of the configurations, the measurements were made at a location of $2.37 \mathrm{~cm}$ from the axial shield to provide adequate clearance between detector and shield for all the mockups that followed. A plot of the results is given in Figure 33.

\section{9 $\mathrm{B}_{4} \mathrm{C}$ ROD BUNDLE $+\mathrm{B}_{4} \mathrm{C}$ HOMOGENEOUS-TYPE ASSEMBLIES (ITEM IVA)}

This configuration consisted of a single hexagon containing 37 cylindrical rods of $\mathrm{B}_{4} \mathrm{C}$ equally spaced in aluminum surrounded by six $\mathrm{B}_{4} \mathrm{C}$ homogeneous-type assemblies. Radial traverses with the three Bonner balls were made at $30 \mathrm{~cm}$ behind the shield and these results are given in Tables 20,21 , and 22 . The axial measurements with the six Bonner balls at 30 and $150 \mathrm{~cm}$ are recorded in Tables 18 and 19. Measurements with the Hornyak button at $2.37 \mathrm{~cm}$ behind the assemblies is shown as part of Table 25, with the data plotted in Figure 34.

\subsection{SS ROD BUNDLE + SS HOMOGENEOUS-TYPE ASSEMBLIES (ITEM IVB)}

This mockup was the counterpart of the previous configuration in which the 37 $\mathrm{B}_{4} \mathrm{C}$ cylindrical rods were exchanged for an equal number of SS rods and the surrounding hexagons were of the SS homogeneous-type. The combination provided yet another shield design for making a direct comparison of the relative shielding properties of $\mathrm{SS}$ and $\mathrm{B}_{4} \mathrm{C}$. Data from the three radial traverses at $30 \mathrm{~cm}$ behind the mockup are listed in Tables 20,21 , and 22 . The axial traverse results with the six Bonner balls at 30 and $150 \mathrm{~cm}$ are located in Tables 18 and 19. The Hornyak button 
responses radially behind the hexagons are listed in Table 25 and plotted in Figure 35.

\subsection{1 $\mathrm{B}_{4} \mathrm{C}$ CENTRAL SODIUM CHANNEL ASSEMBLY + $\mathrm{B}_{4} \mathrm{C}$ HOMOGENEOUS-TYPE ASSSEMBLIES(ITEM VA)}

This $\mathrm{B}_{4} \mathrm{C}$ central sodium channel assembly, described in section 3.7, was surrounded by the six $\mathrm{B}_{4} \mathrm{C}$ homogeneous-type assemblies for this mockup. Radial traverse results with the three Bonner balls at $30 \mathrm{~cm}$ are given in Tables 20,21 , and 22. The axial measurements with the six Bonner balls at 30 and $150 \mathrm{~cm}$ can be found in Tables 18 and 19. The radial measurements with the Hornyak button are contained in Table 25 and plotted in Figure 36.

\subsection{SS CENTRAL SODIUM CHANNEL ASSEMBLY + SS HOMOGENEOUS-TYPE ASSEMBLIES (ITEM VB)}

The central assembly in this group has SS where $\mathrm{B}_{4} \mathrm{C}$ existed in the previous group. It was surrounded by six SS homogeneous assemblies described earlier (section 3.2). The radial traverse measurements with the three Bonner balls are compiled in Tables 20, 21, and 22. The axial traverse data with the six Bonner balls are in Tables 18 and 19. The Hornyak button traverse data radially behind the mockup are grouped with other results in Table 25 and plotted in Figure 37. 


\section{ANALYSIS OF EXPERIMENTAL ERRORS}

The errors associated with the measurements were due to a number of uncertainties: (1) the sizes of the gaps between slabs unavoidably introduced in the configurations; (2) the repeatability of positioning the detectors; (3) the detector count rate statistics and calibrations; (4) the reactor power determinations; and (5) the effects of the exposure of the configurations to the weather. Of these, the uncertainty due to the weather was the least understood and probably beyond simple estimation.

The uncertainty lay in changes in the amount of moisture between the slabs and in the lithiated paraffin surrounding them despite the precautions that were taken. During this experiment the mockups were covered with plastic as well as canvas-type tarpaulins to limit the amount of moisture reaching the slabs. Even so, it was noticed that some moisture appeared at the base of the mockup on rainy days. Thus, for this experiment, the effect of the weather on the data remains unknown.

The TSR-Il power level for each measurement was determined from the output of two fission chambers located in the reactor shield along the midplane of the reactor. The response of these chambers to the reactor source was monitored prior to the experiment through the use of gold foils and found to agree to within about $5 \%$ with previous reactor power comparisons. These detectors were calibrated on a daily basis using a ${ }^{252} \mathrm{Cf}$ source, with the calibration values lying within about a $6 \%$ spread ( $\pm 3 \%$ of an average value) over the experimental period. During any one detector traverse in a given day, the variation in the reactor power indicated by the monitor outputs was at most about $3 \%$. However, during the several months the experiment was being performed, the monitors indicated variations less than $\pm 5 \%$. Thus, the uncertainty in the reactor power determination was assumed to be $\pm 5 \%$.

Count-rate statistics are expressed in a manner specific to each detector. For the NE-213 measurements, counting statistics and unfolding errors are included in the unfolding of the pulse-height spectra using the FERD code, with the resulting flux expressed in terms of lower and upper limits that represented a $68 \%$ confidence interval. Similar errors were expressed in the tabular data for the hydrogen counter measurements unfolded using SPEC4. Neither of the spectra, NE-213 or hydrogen counter, reflects the error in the reactor power determination since this error is not 
included in the unfolding program. This, as seen above, could have been as much as $\pm 5 \%$.

The error in the Hornyak button measurements was largely dependent on the ability to maintain a constant temperature around the detector in the presence of large swings in the ambient temperature. Comparison of the calibration factors using a ${ }^{252} \mathrm{Cf}$ source made before and after a traverse showed an average spread of about $4 \%$. This variation, combined with error limits given for the power determinations, position locations, etc., does not project an overall error beyond that quoted for the other detectors, about $\pm 5 \%$.

The Bonner ball detector was calibrated on a daily basis using ${ }^{252} \mathrm{Cf}$ as a source, with the resulting count rates, normalized to the source strength. This ratio normally falls within about $\pm 3 \%$ of an average value that has been obtained over a period of years. Experimental data is then obtained through the use of a traversing mechanism that moves the detector with respect to the mockup while maintaining reactor power. Physical limitations of the traversing mechanism allows movement of the Bonner ball several millimeters to either side of a straight line as it travels from point to point. For the measurements perpendicular to the configuration centerline at $30 \mathrm{~cm}$ behind the configurations, such variations in the detector position could correspond to changes in the count rate of about $\pm 2 \%$. For the measurements on centerline beyond the $30 \mathrm{~cm}$ point, the error in positioning several millimeters either side of the selected location would lie within the statistics of the measurement.

Rather than calculate probable errors for each measurement in a series of measurements during a traverse, we preferred, in general, to quote a value for the error in the measurements for a given experiment. Thus, assuming the estimated upper limit for all the errors noted above, the errors assigned to both the Bonner ball and Hornyak button detector measurements should lie within about $\pm 10 \%$. 


\section{REFERENCES}

1. R. E. Maerker et al., Calibration of the Bonner Ball Neutron Detectors Used at the Tower Shielding Facility, ORNL/TM-3465 (June 1971).

2. C. E. Burgart and M. B. Emmett, Monte Carlo Calculations of the Response Functions of Bonner Ball Neutron Detectors, ORNL/TM-3739 (April 1972).

3. B. W. Rust, D. T. Ingersoll, and W. R. Burrus, A User's Manual for the FERDO and FERD Unfolding Codes, ORNL/TM-8720 (September 1983).

4. J. O. Johnson and D. T. Ingersoll, User's Guide for the Revised SPEC-4 Neutron Spectrum Unfolding Code, ORNL/TM-7384 (August 1980).

5. F. J. Muckenthaler et al., Measurements for the JASPER Program Fission Gas Plenum Experiment, ORNL/TM-10422 (June 1987).

\section{ACKNOWLEDGEMENTS}

The author is deeply indebted to D. T. Ingersoll and J. V. Pace, III, of ORNL's Engineering Physics and Mathematics Division, to P. B. Hemmig of DOE/Washington, and to the JASPER working group from Japan for their participation and assistance in formulating the Experimental Program Plan. A deep gratitude is expressed to the TSR-Il operating crew of the Research Reactors Division and TSF assigned members of the Instrumentation and Controls Division for not only maintaining a viable source but for experimental help when needed. Appreciation is expressed to E. R. Specht, Rockwell International, W. H. Harless, General Electric Company, R. K. Disney, Westinghouse-ARD, W. L. Bunch, Westinghouse-Hanford for timely suggestions. Special thanks go to G. A. Russell and S. A. Raby for their efforts in editing and preparing this report. 



\section{APPENDIX A}

\section{EXPERIMENTAL PROGRAM PLAN FOR THE JASPER AXIAL SHIELD EXPERIMENT}

I. Spectrum Modifier (SM) Mockup

A. $10 \mathrm{~cm} \mathrm{Fe}+10 \mathrm{~cm} \mathrm{Al}+2.5 \mathrm{~cm}$ boral $+20 \mathrm{~cm}$ radial blanket

1. 3-, 4-, 5-, 8-, 10-, and 12-in. Bonner ball measurements on centerline:
a. at $30 \mathrm{~cm}$ behind shield mockup
b. at $150 \mathrm{~cm}$ behind shield mockup

2. 3-, 5-, and 8-in. Bonner ball horizontal traverse at $30 \mathrm{~cm}$ behind shield mockup

3. NE-213 and hydrogen counter spectrum measurements on centerline as close as feasible behind shield mockup

4. 3-, 5-, and 10-in. Bonner ball measurements on centerline at location of NE-213/H spectrum measurements

\section{Homogeneous Shield Mockup}

A. $\quad \mathrm{SM}+45-\mathrm{cm}$-thick $\mathrm{B}_{4} \mathrm{C}$ homogeneous type assemblies in all seven shield positions

1. 3-, 4-, 5-, 8-, 10-, and 12-in. Bonner ball measurements on centerline:
a. at $30 \mathrm{~cm}$ behind shield mockup
b. at $150 \mathrm{~cm}$ behind shield mockup

2. 3-, 5-, and 8-in. Bonner ball horizontal traverse at $30 \mathrm{~cm}$ behind shield mockup

3. $\quad$ 0.6-cm Hornyak button horizontal traverse as close as possible behind shield mockup

4. NE-213 and hydrogen counter spectrum measurements on centerline as close as feasible behind shield mockup 
5. 3-, 5-, and 10-in. Bonner ball measurements on centerline at location of NE-213/H spectrum measurements

B. $\mathrm{SM}+45-\mathrm{cm}$-thick SS-304 homogeneous type assemblies in all seven shield positions

1. 3-, 4-, 5-, 8-, 10-, and 12-in. Bonner ball measurements on centerline:
a. at $30 \mathrm{~cm}$ behind shield mockup
b. at $150 \mathrm{~cm}$ behind shield mockup

2. 3-, 5-, and 8-in. Bonner ball horizontal traverse at $30 \mathrm{~cm}$ behind shield mockup

3. $\quad$ 0.6-cm Hornyak button horizontal traverse as close as possible behind shield mockup

4. NE-213 and hydrogen counter spectrum measurements on centerline as close as feasible behind shield mockup

5. 3-, 5-, and 10-in. Bonner ball measurements on centerline at location of $\mathrm{NE}-213 / \mathrm{H}$ spectrum measurements

\section{Central Blockage Shield Mockup}

A. $\quad \mathrm{SM}+45-\mathrm{cm}$-thick $\mathrm{B}_{4} \mathrm{C}$ central blockage type assembly in center shield position with $\mathrm{B}_{4} \mathrm{C}$ homogeneous type assemblies in outer six shield positions

1. 3-, 4-, 5-, 8-, 10-, and 12-in. Bonner ball measurements on centerline:
a. at $30 \mathrm{~cm}$ behind shield mockup
b. at $150 \mathrm{~cm}$ behind shield mockup

2. 3-, 5-, and 8-in. Bonner ball horizontal traverse at $30 \mathrm{~cm}$ behind shield mockup

3. $\quad 0.6-\mathrm{cm}$ Hornyak button horizontal traverse as close as possible behind shield mockup

B. $\quad \mathrm{SM}+45-\mathrm{cm}$-thick $\mathrm{B}_{4} \mathrm{C}$ central blockage type assemblies in all seven shield positions 
1. 3-, 4-, 5-, 8-, 10-, and 12-in. Bonner ball measurements on centerline:
a. at $30 \mathrm{~cm}$ behind shield mockup
b. at $150 \mathrm{~cm}$ behind shield mockup

2. 3-, 5-, and 8-in. Bonner ball horizontal traverse at $30 \mathrm{~cm}$ behind shield mockup

3. $\quad 0.6-\mathrm{cm}$ Hornyak button horizontal traverse as close as possible behind shield mockup

C. $\mathrm{SM}+45-\mathrm{cm}$-thick SS-304 central blockage type assembly in center shield position with SS-304 homogeneous type assemblies in outer six shield positions

1. 3-, 4-, 5-, 8-, 10-, and 12-in. Bonner ball measurements on centerline:
a. at $30 \mathrm{~cm}$ behind shield mockup
b. at $150 \mathrm{~cm}$ behind shield mockup

2. 3-, 5-, and 8-in. Bonner ball horizontal traverse at $30 \mathrm{~cm}$ behind shield mockup

3. $\quad$ 0.6-cm Hornyak button horizontal traverse as close as possible behind shield mockup

D. SM + 45-cm-thick SS-304 central blockage type assemblies in all seven shield positions

1. 3-, 4-, 5-, 8-, 10-, and 12-in. Bonner ball measurements on centerline:
a. at $30 \mathrm{~cm}$ behind shield mockup
b. at $150 \mathrm{~cm}$ behind shield mockup

2. 3-, 5-, and 8-in. Bonner ball horizontal traverse at $30 \mathrm{~cm}$ behind shield mockup

3. $\quad 0.6-\mathrm{cm}$ Hornyak button horizontal traverse as close as possible behind shield mockup

E. $\quad \mathrm{SM}+20$-cm-thick fission gas plenum mockup $+45-\mathrm{cm}$-thick $\mathrm{B}_{4} \mathrm{C}$ central blockage type assemblies in all seven shield positions 
1. 3-, 4-, 5-, 8-, 10-, and 12-in. Bonner ball measurements on centerline:
a. at $30 \mathrm{~cm}$ behind shield mockup
b. at $150 \mathrm{~cm}$ behind shield mockup

2. 3-, 5-, and 8-in. Bonner ball horizontal traverse at $30 \mathrm{~cm}$ behind shield mockup

3. $0.6-\mathrm{cm}$ Hornyak button horizontal traverse as close as possible behind shield mockup

IN. Rod Bundle Shield Mockup

A. $\quad \mathrm{SM}+45-\mathrm{cm}$-thick $\mathrm{B}_{4} \mathrm{C}$ rod bundle type assembly in center shield position with $\mathrm{B}_{4} \mathrm{C}$ homogeneous type assemblies in outer six shield positions

1. 3-, 4-, 5-, 8-, 10-, and 12-in. Bonner ball measurements on centerline:
a. at $30 \mathrm{~cm}$ behind shield mockup
b. at $150 \mathrm{~cm}$ behind shield mockup

2. 3-, 5-, and 8-in. Bonner ball horizontal traverse at $30 \mathrm{~cm}$ behind shield mockup

3. 0.6-cm Hornyak button horizontal traverse as close as possible behind shield mockup

B. SM + 45-cm-thick SS-304 rod bundle type assembly in center shield position with SS-304 homogeneous type assemblies in outer six shield positions

1. 3-, 4-, 5-, 8-, 10-, and 12-in. Bonner ball measurements on centerline:
a. at $30 \mathrm{~cm}$ behind shield mockup
b. at $150 \mathrm{~cm}$ behind shield mockup

2. 3-, 5-, and 8-in. Bonner ball horizontal traverse at $30 \mathrm{~cm}$ behind shield mockup

3. $\quad$ 0.6- $\mathrm{cm}$ Hornyak button horizontal traverse as close as possible behind shield mockup 
V. Central Sodium Channel Shield Mockup

A. $\quad S M+45-c m$-thick $B_{4} C$ central sodium channel type assembly in center shield position with $\mathrm{B}_{4} \mathrm{C}$ homogeneous type assemblies in outer six shield positions

1. 3-, 4-, 5-, 8-, 10-, and 12-in. Bonner ball measurements on centerline:
a. at $30 \mathrm{~cm}$ behind shield mockup
b. at $150 \mathrm{~cm}$ behind shield mockup

2. 3-, 5-, and 8-in. Bonner ball horizontal traverse at $30 \mathrm{~cm}$ behind shield mockup

3. $0.6-\mathrm{cm}$ Hornyak button horizontal traverse as close as possible behind shield mockup

B. $\quad \mathrm{SM}+45-\mathrm{cm}$-thick SS-304 central sodium channel type assembly in center shield position with SS-304 homogeneous type assemblies in outer six shield positions

1. 3-, 4-, 5-, 8-, 10-, and 12-in. Bonner ball measurements on centerline:
a. at $30 \mathrm{~cm}$ behind shield mockup
b. at $150 \mathrm{~cm}$ behind shield mockup

2. 3-, 5-, and 8-in. Bonner ball horizontal traverse at $30 \mathrm{~cm}$ behind shield mockup

3. 0.6- $\mathrm{cm}$ Hornyak button horizontal traverse as close as possible behind shield mockup 

APPENDIX B

TABLES OF DATA 

Table 1. Analysis of iron slabs $(\rho=7.86 \mathrm{~g} / \mathrm{cc})$ used in spectrum modifier

\begin{tabular}{lc}
\hline Element & wt \% \\
\hline $\mathrm{Fe}$ & 98.4 \\
$\mathrm{C}$ & .25 \\
$\mathrm{Cr}$ & .15 \\
$\mathrm{Cu}$ & .03 \\
$\mathrm{Mn}$ & 1.0 \\
$\mathrm{Mo}$ & .02 \\
$\mathrm{Ni}$ & .05 \\
$\mathrm{Si}$ & .25 \\
\hline
\end{tabular}

Table 2. Analysis of 6061 aluminum ( $\rho=2.70 \mathrm{~g} / \mathrm{cc}$ )

\begin{tabular}{ccr} 
Element & wt \% & ppm \\
\hline & & \\
$\mathrm{Al}$ & 97.5 & \\
$\mathrm{Cr}$ & .22 & \\
$\mathrm{Cu}$ & .23 & \\
$\mathrm{Fe}$ & .47 & \\
$\mathrm{Mg}$ & .86 & \\
$\mathrm{Mn}$ & .01 & \\
$\mathrm{Si}$ & .63 & \\
$\mathrm{Ti}$ & .042 & \\
$\mathrm{Zn}$ & .07 & \\
$\mathrm{Li}$ & & 3 \\
$\mathrm{Ni}$ & & 50 \\
$\mathrm{Sn}$ & & $<10$ \\
$\mathrm{~V}$ & & 150 \\
& & \\
\hline
\end{tabular}


Table 3. Composition of boral slabs used in spectrum modifier

\begin{tabular}{|c|c|c|c|}
\hline \multirow[b]{2}{*}{ Component } & \multicolumn{3}{|c|}{$\left(\mathrm{B}_{4} \mathrm{C}-40-43\right.$ vol $\%$ in $\mathrm{B}_{4} \mathrm{C}-\mathrm{Al}$ mixture) } \\
\hline & $\begin{array}{c}\text { Density } \\
\text { (g/cc) }\end{array}$ & $\begin{array}{l}\text { Elemental } \\
\text { Composition } \\
\text { (wt \%) }\end{array}$ & $\begin{array}{l}\text { With } \\
\text { Al Cladding } \\
(w t \%)\end{array}$ \\
\hline $\mathrm{B}_{4} \mathrm{C}$ & 2.3 & & \\
\hline $\mathrm{Al}^{4}$ & 2.70 & 65 & $\sim 75$ \\
\hline$B$ & & 27.5 & $\sim 19.6$ \\
\hline $\mathrm{C}$ & & 7.5 & $\sim 5.4$ \\
\hline
\end{tabular}


Table 4. Composition of $\mathrm{UO}_{2}$ radial blanket

\begin{tabular}{lcc}
\hline Component & vol \% & $\begin{array}{c}\text { Density } \\
(\mathrm{g} / \mathrm{cc})\end{array}$ \\
\hline $\mathrm{UO}_{2}$ (pellets) & 64.6 & 10.28 \\
$\mathrm{Al}(8001)$ & 11.2 & 2.8 \\
$\mathrm{Na}$ & 23.2 & 0.92 \\
Void & 1.0 & --- \\
\hline
\end{tabular}

$\mathrm{UO}_{2}$ content $88.18 \mathrm{wt} \%$

Isotope \%

\begin{tabular}{|c|c|c|c|c|c|}
\hline & $\begin{array}{l}{ }^{234} U \\
{ }^{235} U\end{array}$ & $\begin{array}{l}.0053 \\
.713\end{array}$ & ${ }^{236} \mathrm{U}$ & 99.28 & \\
\hline \multicolumn{6}{|c|}{ Metallic Impurities in $\mathrm{UO}_{2}(\mathrm{ppm})^{*}$} \\
\hline $\mathrm{Al}$ & $<20$ & $\mathrm{Cu}$ & 1 & $\mathrm{Na}$ & $<20$ \\
\hline$B$ & $<1$ & $F$ & $<2$ & $\mathrm{Ni}$ & $<10$ \\
\hline $\mathrm{Be}$ & $<2$ & $\mathrm{Fe}$ & $<20$ & $\mathrm{~Pb}$ & $<4$ \\
\hline $\mathrm{Bi}$ & $<2$ & $\mathrm{H}_{2} \mathrm{O}$ & 2.1 & $\mathrm{Si}$ & $<20$ \\
\hline$C$ & $<10$ & $\mathrm{Li}^{2}$ & $<1$ & Sn & $<2$ \\
\hline $\mathrm{Ca}$ & $<20$ & $\mathrm{Mg}$ & $<10$ & $\mathrm{Ta}$ & $<25$ \\
\hline $\mathrm{Cd}$ & $<0.5$ & $\mathrm{Mn}$ & $<4$ & Tu & $<4$ \\
\hline $\mathrm{Cl}$ & $<3.3$ & Mo & $<10$ & $W$ & $<25$ \\
\hline Co & $<2$ & $N$ & 54 & $\mathrm{Zr}$ & $<25$ \\
\hline $\mathrm{Cr}$ & $<10$ & & & & \\
\hline
\end{tabular}


Table 5. Analysis of aluminum used in $\mathrm{UO}_{2}$ radial blanket cladding $(\rho=2.7 \mathrm{~g} / \mathrm{cc}$ )

\begin{tabular}{ccc}
\hline & & \\
Element & wt \% & ppm \\
& & \\
$\mathrm{Al}$ & $\mathrm{M}$ & \\
$\mathrm{Fe}$ & .59 & \\
$\mathrm{Ni}$ & 1.13 & \\
$\mathrm{~B}$ & & $<6$ \\
$\mathrm{Be}$ & & $<20$ \\
$\mathrm{Cd}$ & & $<20$ \\
$\mathrm{Co}$ & & $<20$ \\
$\mathrm{Cr}$ & & $<6$ \\
$\mathrm{Cu}$ & 52.9 \\
$\mathrm{Li}$ & 6 \\
$\mathrm{Ng}$ & & 3.04 \\
$\mathrm{Mn}$ & & 11.2 \\
$\mathrm{Mo}$ & $<6$ \\
$\mathrm{~Pb}$ & $<20$ \\
$\mathrm{Si}$ & 27.5 \\
$\mathrm{Sn}$ & $<60$ \\
$\mathrm{~T}$ & $<2000$ \\
$\mathrm{Ti}$ & 65.5 \\
$\mathrm{~V}$ & 44.2 \\
$\mathrm{~W}$ & $<60$ \\
$\mathrm{Zr}$ & $<20$ \\
& \\
\hline &
\end{tabular}

Table 6. Composition of lithiated-paraffin bricks ( $\rho=1.15 \mathrm{~g} / \mathrm{cc}$ )

\begin{tabular}{lc}
\hline Component & wt \% \\
\hline $\mathrm{CnH}_{2} \mathrm{n}+2$ & 60 \\
$\mathrm{Li}_{2} \mathrm{CO}_{3}$ & 40 \\
\hline
\end{tabular}


Table 7. Composition of the small concrete blocks on each side of the spectrum modifier $(\rho=2.39 \mathrm{~g} / \mathrm{cc})$

\begin{tabular}{cc}
\hline Element & wt \% \\
\hline $\mathrm{C}$ & 10.36 \\
$\mathrm{O}$ & 49.03 \\
$\mathrm{Ca}$ & 38.05 \\
$\mathrm{Fe}$ & 0.37 \\
$\mathrm{Si}$ & 0.78 \\
$\mathrm{Mg}$ & 0.23 \\
$\mathrm{~S}$ & 0.17 \\
$\mathrm{P}$ & 0.04 \\
$\mathrm{Na}$ & 0.03 \\
$\mathrm{~K}$ & 0.04 \\
$\mathrm{H}$ & 0.42 \\
$\mathrm{R}^{*}$ & 0.47 \\
\hline & 99.99 \\
\hline Possibly other traces of metals.
\end{tabular}


Table 8. Analysis of type 304 stainless steel ( $\rho=7.92 \mathrm{~g} / \mathrm{cc}$ )

\begin{tabular}{lcc}
\hline Element & \multicolumn{2}{c}{$w t \%$} \\
\hline $\mathrm{Fe}$ & 68.1 & -71.2 \\
$\mathrm{Cr}$ & 18.0 & -19.1 \\
$\mathrm{Ni}$ & 8.8 & -9.8 \\
$\mathrm{Mn}$ & $1.04-1.65$ \\
$\mathrm{Si}$ & $.33-$ & .65 \\
$\mathrm{C}$ & $.024-$ & .085 \\
$\mathrm{O}_{2}$ & $.013-$ & .021 \\
$\mathrm{P}$ & & .028 \\
$\mathrm{~S}$ & & .022 \\
$\mathrm{Mo}$ & & .30 \\
$\mathrm{Cu}$ & & .26 \\
$\mathrm{Co}$ & & .10 \\
\hline
\end{tabular}


Table 9. Analysis of $B_{4} C$ in hexagon assemblies $(\rho=1.41 \mathrm{~g} / \mathrm{cc})$

\begin{tabular}{lrrr}
\hline Sample \# & \% Boron & \% Carbon & \% Boron Nitride \\
\hline & & & \\
1 & 78.2 & 20.0 & 1.8 \\
2 & 78.0 & 20.4 & 1.6 \\
3 & 78.2 & 20.0 & 1.8 \\
\hline & & & \\
Element & Sample \#1 & Sample \#2* & Sample \#3 \\
& & & \\
\hline & & & \\
$\mathrm{Al}$ & 5 & 10 & 3 \\
$\mathrm{Ca}$ & 5 & 5 & 30 \\
$\mathrm{Co}$ & $<1$ & $<1$ & $<1$ \\
$\mathrm{Cr}$ & 1 & 3 & 3 \\
$\mathrm{Cl}$ & 3 & 5 & 3 \\
$\mathrm{Cu}$ & 3 & 3 & 3 \\
$\mathrm{Fe}$ & 10 & 50 & 50 \\
$\mathrm{Mg}$ & $<5$ & 10 & 5 \\
$\mathrm{Mn}$ & 1 & 3 & 5 \\
$\mathrm{Na}$ & 5 & 10 & 30 \\
$\mathrm{P}$ & 3 & 3 & 3 \\
$\mathrm{Sc}$ & 3 & 3 & 3 \\
$\mathrm{Si}$ & $<20$ & $<20$ & $<20$ \\
$\mathrm{Ti}$ & 3 & 3 & 10 \\
& & & \\
\hline
\end{tabular}

parts per million 
Table 10. Analysis of 304 SS in tubes used for $\mathrm{B}_{4} \mathrm{C}$ rod bundle ( $\rho=7.92 \mathrm{~g} / \mathrm{cc}$ )

\begin{tabular}{lc}
\hline Element & wt \% \\
\hline $\mathrm{Fe}$ & 70.3 \\
$\mathrm{Co}$ & .11 \\
$\mathrm{Cr}$ & 18.3 \\
$\mathrm{Cu}$ & .37 \\
$\mathrm{Mn}$ & 1.24 \\
$\mathrm{Mo}$ & .32 \\
$\mathrm{Ni}$ & 9.0 \\
$\mathrm{Si}$ & .31 \\
$\mathrm{Ti}$ & .023 \\
\hline
\end{tabular}


Table 11. Analysis of type 304 stainless steel sheets used in fission gas plenums $(\rho=7.92 \mathrm{~g} / \mathrm{cc})$

\begin{tabular}{cc}
\hline & Element \\
& wt \% \\
\hline $\mathrm{Co}$ & $<0.001$ \\
$\mathrm{Cr}$ & 19.2 \\
$\mathrm{Cu}$ & 0.15 \\
$\mathrm{Fe}$ & 69.0 \\
$\mathrm{Mn}$ & 1.7 \\
$\mathrm{Mo}$ & 0.21 \\
$\mathrm{Ni}$ & 9.2 \\
$\mathrm{Si}$ & 0.46 \\
$\mathrm{Ti}$ & $<0.02$ \\
\hline
\end{tabular}


Table 12. Analysis of (6061-T6) aluminum sheets used in fission gas plenum $(\rho=2.70 \mathrm{~g} / \mathrm{cc})$

\begin{tabular}{lc}
\hline Element & wt \% \\
\hline & \\
$\mathrm{Al}$ & major \\
$\mathrm{Co}$ & $<0.001$ \\
$\mathrm{Cr}$ & 0.17 \\
$\mathrm{Cu}$ & 0.28 \\
$\mathrm{Fe}$ & 0.42 \\
$\mathrm{Li}$ & $<0.001$ \\
$\mathrm{Mg}$ & 1.04 \\
$\mathrm{Mn}$ & 0.11 \\
$\mathrm{Ni}$ & $<0.001$ \\
$\mathrm{Si}$ & 0.68 \\
$\mathrm{SN}$ & $<0.001$ \\
$\mathrm{Ti}$ & 0.025 \\
$\mathrm{~V}$ & $<0.001$ \\
$\mathrm{Zn}$ & 0.15 \\
& \\
\hline
\end{tabular}


Table 12A. Analysis of lead slab used as part of mockup in IIA, B ( $\rho=11.35 \mathrm{~g} / \mathrm{cc}$ )

\begin{tabular}{ccc}
\hline Element & wt\% & PPM \\
\hline Lead & 99.9 & \\
$\mathrm{Al}$ & & $<3$ \\
$\mathrm{Ag}$ & & 30 \\
$\mathrm{~B}$ & & $<1$ \\
$\mathrm{Ca}$ & & 1 \\
$\mathrm{Cr}$ & 10 \\
$\mathrm{Cu}$ & & 800 \\
$\mathrm{Fe}$ & 1 \\
$\mathrm{Li}$ & 20 \\
$\mathrm{Mg}$ & & $<3$ \\
$\mathrm{Mn}$ & & 5 \\
$\mathrm{Na}$ & & 1 \\
$\mathrm{Ni}$ & & 30 \\
$\mathrm{P}$ & & 5 \\
$\mathrm{Si}$ & & $<3$ \\
$\mathrm{Sn}$ & & 30 \\
\hline
\end{tabular}


Table 13. Analysis of concrete slab used to contain the fission gas plenum ( $\rho=2.44 \mathrm{~g} / \mathrm{cc}$ )

\begin{tabular}{lc}
\hline \multicolumn{1}{c}{ Element } & wt \% \\
\hline & \\
$\mathrm{Al}_{2} \mathrm{O}_{3}$ & 2.43 \\
$\mathrm{CaO}$ & 36.78 \\
$\mathrm{CO}_{3}$ & 44.3 \\
$\mathrm{Fe}_{2} \mathrm{O}_{3}$ & .92 \\
$\mathrm{H}_{2} \mathrm{O}$ (Bound) & 2.10 \\
$\mathrm{H}_{2} \mathrm{O}$ (Free) & .26 \\
$\mathrm{~K}_{2} \mathrm{O}$ & .57 \\
$\mathrm{LOI}^{*}$ & 35.62 \\
$\mathrm{MgO}^{*}$ & 13.78 \\
$\mathrm{Na}_{2} \mathrm{O}$ & .13 \\
$\mathrm{P}_{2} \mathrm{O}_{5}$ & .0285 \\
$\mathrm{SiO}_{2}$ & 8.54 \\
$\mathrm{SO}_{3}$ & .53 \\
& \\
\hline
\end{tabular}

"LOI (Lost on Ignition) includes the free and bound $\mathrm{H}_{2} \mathrm{O}$ and $\mathrm{SO}_{3}$. To obtain correct wt\% for the materials, multiply $\mathrm{CO}_{3}$ value by .7334 to get $\mathrm{CO}_{2}$ and when summed the LOI values should not be included. 
Table 14. Analysis of concrete in axial shield concrete slab $(\rho=2.40 \mathrm{~g} / \mathrm{cc}$ )

\begin{tabular}{lc}
\hline Element & $\begin{array}{c}\text { Axial shield } \\
\text { concrete } \\
(\%)\end{array}$ \\
\hline Free $\mathrm{H}_{2} \mathrm{O}$ & \\
$\mathrm{Bound}^{\mathrm{H}} \mathrm{H}_{2} \mathrm{O}$ & .97 \\
$\mathrm{LOI}^{*}$ & 2.44 \\
$\mathrm{SiO}_{2}$ & 35.25 \\
$\mathrm{Fe}_{2} \mathrm{O}_{3}$ & 9.41 \\
$\mathrm{Al}_{2} \mathrm{O}_{3}$ & .94 \\
$\mathrm{CaO}$ & 1.57 \\
$\mathrm{MgO}$ & 36.96 \\
$\mathrm{Na}_{2} \mathrm{O}$ & 13.2 \\
$\mathrm{~K}_{2} \mathrm{O}$ & .022 \\
$\mathrm{SO}_{3}$ & .53 \\
$\mathrm{P}_{2} \mathrm{O}_{5}$ & .16 \\
$\mathrm{CO}_{3}$ & .10 \\
\hline
\end{tabular}

"LOI (Lost on Ignition) includes the free and bound $\mathrm{H}_{2} \mathrm{O}$ and $\mathrm{SO}_{3}$. To obtain correct wt\% for the materials, multiply $\mathrm{CO}_{3}$ value by .7334 to get $\mathrm{CO}_{2}$ and when summed the LOI values should not be included. 
Table 15. Fast neutron fluxes (> $0.8 \mathrm{MeV}$ ) on centerline at $179.1 \mathrm{~cm}$ behind the radial blanket (Item (A): Run 7888A

\begin{tabular}{|c|c|c|c|c|c|}
\hline $\begin{array}{l}\text { Neutron } \\
\text { Energy } \\
\text { (MeV) }\end{array}$ & \multicolumn{2}{|c|}{ Flux (neutrons $\mathrm{cm}^{2} \mathrm{~W}^{-1} \mathrm{~kW}^{-1} \mathrm{~s}^{-1}$ ) } & $\begin{array}{c}\text { Neutron } \\
\text { Energy } \\
\text { (MoV) }\end{array}$ & $\begin{array}{c}\text { Flux (neutrons } \\
\text { Lower } \\
\text { Limit }\end{array}$ & $\begin{array}{c}\left.\mathrm{MeV}^{-1} \cdot \mathrm{kW} \mathrm{W}^{-1} \mathrm{~s}^{-1}\right) \\
\text { Upper } \\
\text { Limit }\end{array}$ \\
\hline $8.11 E(.1)$ & $2.65 E \quad(4)$ & $2.67 E$ (4) & $594 E \quad(0)$ & $5.25 E \quad(2)$ & $5.70 E \quad(2)$ \\
\hline $9.07 E(.1)$ & $2.40 E \quad$ (4) & $2.41 E \quad(4)$ & $625 E \quad(0)$ & $4.40 E \quad(2)$ & $4.62 E$ (2) \\
\hline $1.01 E(0)$ & $1.88 E \quad(4)$ & $1.89 E \quad(4)$ & $6.55 E \quad(0)$ & $3.64 E \quad$ (2) & $3.82 E \quad$ (2) \\
\hline $1.11 E(0)$ & $1.57 E$ (A) & $1.59 E$ (4) & $6.84 E(0)$ & $3.15 E \quad(2)$ & $3.28 E \quad(2)$ \\
\hline $1.20 E(0)$ & $1.43 E \quad(4)$ & $1.44 E(4)$ & $7.24 E \quad(0)$ & $2.63 E \quad(2)$ & $2.73 E \quad(2)$ \\
\hline $1.31 E(0)$ & $1.32 E \quad$ (4) & $1.33 E$ (4) & $7.74 E \quad(0)$ & $1.92 E \quad$ (2) & $2.04 E$ \\
\hline $1.41 E(0)$ & $1.21 E \quad(4)$ & $1.22 E \quad(4)$ & $8.24 E \quad(0)$ & $1.34 E \quad$ (2) & $1.46 E \quad(2)$ \\
\hline $1.51 E(0)$ & $1.10 E \quad(4)$ & $1.11 E \quad(4)$ & $8.76 E \cdot(0)$ & $984 E \quad(1)$ & $1.04 E \quad(2)$ \\
\hline $1.61 E(0)$ & $9.92 E$ & $1.00 E \quad(4)$ & $926 E \quad(0)$ & $7.25 E \quad(1)$ & $7.79 E \quad(1)$ \\
\hline $1.71 E(0)$ & $9.02 E \quad(3)$ & $9.10 E \quad(3)$ & $9.74 E \quad(0)$ & $5.59 E$ (1) & $6.00 E(1)$ \\
\hline $1.81 E(0)$ & $8.32 E$ & $8.40 E \quad(3)$ & $1.03 E(1)$ & $4.32 E$ & $4.70 E$ (1) \\
\hline $1.93 E(0)$ & $7.81 E \quad(3)$ & $7.88 E \quad(3)$ & $1.08 E$ & $307 E$ (1) & $340 E$ (1) \\
\hline $2.10 E(0)$ & $7.31 E \quad$ (3) & $7.39 E \quad(3)$ & $1.12 E \quad(1)$ & $2.03 E \quad(1)$ & $2.28 E \quad(1)$ \\
\hline $2.30 E(0)$ & $6.54 E \quad(3)$ & $6.60 E \quad(3)$ & $1.18 E \quad(1)$ & $1.25 E$ & $1.46 E \quad(1)$ \\
\hline $2.50 E(0)$ & $5.56 \mathrm{E}$ & $5.62 E \quad(3)$ & $1.24 E(1)$ & $751 E \quad(0)$ & $9.47 E \quad(0)$ \\
\hline $270 E(0)$ & $4.55 E$ & $4.60 E \quad(3)$ & $132 E$ & $486 E(0)$ & $6.11 E(0)$ \\
\hline $2.90 E\langle 0\rangle$ & $3.68 E \quad$ (3) & $3.73 E \quad(3)$ & $1.40 E$ (1) & $308 E(0)$ & $4.22 E(0)$ \\
\hline 3.10E (0) & $2.88 E \quad(3)$ & $2.93 E \quad(3)$ & $1.48 E(1)$ & $1.73 E \quad(0)$ & $2.61 E(0)$ \\
\hline $3.30 E(0)$ & $2.23 E \quad(3)$ & $2.27 E \quad(3)$ & $1.56 E \quad(1)$ & $5.77 E(.1)$ & $1.35 E(0)$ \\
\hline $3.50 E(0)$ & $1.78 \mathrm{E}$ & $1.83 E \quad(3)$ & $1.65 E(1)$ & $398 E(.1)$ & $9.12 E(-1)$ \\
\hline $3.71 E(0)$ & $1.54 E \quad(3)$ & $1.57 E \quad(3)$ & $1.75 E(1)$ & $1.62 E(\cdot 1)$ & $6.10 \mathrm{E}(-1)$ \\
\hline $3.91 E(0)$ & $1.41 E \quad(3)$ & $1.45 E \quad(3)$ & $1.85 E(1)$ & $-1.47 \mathrm{E}(\cdot 1)$ & $1.65 E(-1)$ \\
\hline $4.15 E(0)$ & $1.31 E$ (3) & $1.34 E(3)$ & $1.95 E$ & $-1.87 E(-1)$ & $4.92 E(-2)$ \\
\hline $4.45 E \quad(0)$ & $1.20 E(3)$ & $1.22 E$ & $205 E$ & $.1 .93 E(\cdot 1)$ & $1.55 E(.1)$ \\
\hline $4.75 E(0)$ & $1.07 E \quad(3)$ & $1.10 E \quad(3)$ & $2.16 E \quad(1)$ & $-1.83 E(-1)$ & $1.81 E(.9)$ \\
\hline $5.04 E \quad(0)$ & $9.18 E \quad(2)$ & $9.38 E$ (2) & $2.26 E \quad(1)$ & $.1 .15 E(\cdot 1)$ & $1.19 E(-1)$ \\
\hline $5.34 \mathrm{E} \quad(0)$ & $7.71 E \quad(2)$ & $7.89 E \quad(2)$ & $2.35 E$ & $-1.00 E(.1)$ & $1.08 E(-1)$ \\
\hline $5.64 E(0)$ & $6.61 E \quad(2)$ & $6.81 E \quad(2)$ & & & \\
\hline
\end{tabular}

\begin{tabular}{cccc}
\hline $\begin{array}{c}\text { E1 } \\
(\mathrm{M} \theta \mathrm{V})\end{array}$ & $\begin{array}{c}\text { E2 } \\
(\mathrm{MeV})\end{array}$ & $\begin{array}{c}\text { Integral } \\
\left.\text { (neutrons } \mathrm{cm}^{-2} \cdot \mathrm{s}^{-1} \cdot \mathrm{kW}^{-1}\right)\end{array}$ & $\begin{array}{c}\text { Error } \\
\left.\text { (neutrons } \mathrm{cm}^{-2} \cdot \mathrm{s}^{-1} \cdot \mathrm{kW}^{-1}\right)\end{array}$ \\
\hline .811 & 1.000 & $4.47 E(3)$ & $1.50 E(1)$ \\
1.000 & 1.200 & $3.25 E(3)$ & $1.18 E(1)$ \\
1.200 & 1.600 & $4.89 E(3)$ & $2.07 E(1)$ \\
1.600 & 2.000 & $3.43 E(3)$ & $1.55 E(1)$ \\
2.000 & 3.000 & $5.55 E(3)$ & $2.83 E(1)$ \\
3.000 & 4.000 & $1.99 E(3)$ & $2.00 E(1)$ \\
4.000 & 6.000 & $1.92 E(3)$ & $2.21 E(1)$ \\
6.000 & 8.000 & $6.28 E(2)$ & $1.42 E(1)$ \\
8.000 & 10.000 & $1.88 E(2)$ & $6.85 E(0)$ \\
10.000 & 12.000 & $5.66 E(1)$ & $2.91 E(0)$ \\
12.000 & 16.000 & $1.69 E(1)$ & $2.37 E(0)$ \\
16.000 & 20.000 & $1.02 E(0)$ & $7.77 E(-1)$ \\
3.000 & 10.000 & $4.72 E(3)$ & $634 E(1)$ \\
1.500 & 15.000 & $1.48 E(4)$ & $1.17 E(2)$ \\
3.000 & 12000 & $4.78 E(3)$ & $6.62 E(1)$ \\
\hline
\end{tabular}

$* 8 \cdot 11 E(-1)$ read as $8.11 * 10^{-1}$ 
Table 16. Neutron fluxes (50 keV to $1.4 \mathrm{MeV}$ ) on centerline at $179.1 \mathrm{~cm}$ behind the radial blanket (ttem IA):

Runs 1561D, 1561A, 1560A

\begin{tabular}{|c|c|c|c|c|}
\hline$N$ & Energy & $\begin{array}{l}\text { oundary } \\
\text { (MoV) }\end{array}$ & $\begin{array}{c}\text { Flux } \\
\text { (neutrons } \mathrm{cm}^{-2} \cdot \mathrm{MeV}^{-1} \mathrm{~kW} W^{-1} \cdot \mathrm{s}^{-1} \text { ) }\end{array}$ & $\begin{array}{c}\text { Error } \\
(\%)\end{array}$ \\
\hline \multicolumn{5}{|c|}{ Run 15610} \\
\hline 1 & 0.0282 & 0.0334 & $1.25 E(6)^{*}$ & 1.27 \\
\hline 2 & 0.0334 & 0.0385 & $8.77 E \quad(5)$ & 2.01 \\
\hline 3 & 0.0385 & 0.0453 & $7.87 E \quad(5)$ & 1.89 \\
\hline 4 & 0.0453 & 0.0539 & $8.48 E \quad(5)$ & 1.57 \\
\hline 5 & 0.0539 & 0.0624 & $7.98 E \quad$ (5) & 1.85 \\
\hline 6 & 0.0624 & 0.0744 & $8.07 E \quad(5)$ & 1.39 \\
\hline 7 & 0.0744 & 0.0881 & $7.00 E \quad(5)$ & 1.51 \\
\hline 8 & 0.0881 & 0.1035 & $461 E$ (5) & 2.20 \\
\hline 9 & 0.1035 & 0.1206 & $4.71 E \quad(5)$ & 2.12 \\
\hline 10 & 0.1206 & 0.1428 & $479 E \quad$ (5) & 1.65 \\
\hline 11 & 0.1428 & 0.1685 & $333 E \quad(5)$ & 2.18 \\
\hline \multicolumn{5}{|c|}{ Run $1561 \mathrm{~A}$} \\
\hline 1 & 0.1209 & 0.1447 & $4.50 E \quad(5)$ & 1.14 \\
\hline 2 & 0.1447 & 01685 & $334 E$ (5) & 168 \\
\hline 3 & 0.1685 & 0.1962 & $2.99 E \quad(5)$ & 1.72 \\
\hline 4 & 0.1962 & 0.2319 & $2.43 E \quad(5)$ & 1.71 \\
\hline 5 & 0.2319 & 0.2755 & $2.09 E \quad(5)$ & 1.70 \\
\hline \multicolumn{5}{|c|}{ Run $1560 \mathrm{~A}$} \\
\hline 1 & 0.1968 & 0.2305 & $2.22 E$ & 061 \\
\hline 2 & 0.2305 & 0.2755 & $198 E$ & 057 \\
\hline 3 & 0.2755 & 0.3205 & $1.61 E \quad(5)$ & 0.76 \\
\hline 4 & 0.3205 & 0.3767 & $1.14 E \quad(5)$ & 0.92 \\
\hline 5 & 0.3767 & 0.4442 & $7.06 E \quad(4)$ & 135 \\
\hline 6 & 0.4442 & 0.5229 & $7.47 E$ (4) & 1.20 \\
\hline 7 & 0.5229 & 0.6241 & $8.24 E$ (4) & 0.88 \\
\hline 8 & 0.6241 & 0.7253 & $598 E \quad(4)$ & 1.26 \\
\hline 9 & 0.7253 & 0.8602 & $4.03 E \quad(4)$ & 137 \\
\hline 10 & 0.8602 & 1.0064 & $205 E \quad(4)$ & 262 \\
\hline 11 & 1.0064 & 1.1863 & $1.40 E$ & 3.27 \\
\hline 12 & 1.1863 & 1.4000 & $1.26 E \quad(4)$ & 3.20 \\
\hline
\end{tabular}

*1.25E (6) read as $1.25 * 10^{6}$. 
Table 17. Bonner ball measurements on centerline at NE-213 location (Items IA, IIA, IIB)

\begin{tabular}{|c|c|c|c|c|c|c|}
\hline \multirow[b]{3}{*}{ Configuration $^{2}$} & \multicolumn{6}{|c|}{ Bonner ball count rates $\left(\mathrm{s}^{-1} \mathrm{~W}^{-1}\right)$} \\
\hline & \multicolumn{2}{|c|}{ 3-inch Diam Ball } & \multicolumn{2}{|c|}{ 5-Inch Diam Ball } & \multicolumn{2}{|c|}{ 10-inch Diam Ball } \\
\hline & Foreground ${ }^{b}$ & Background ${ }^{c}$ & Foreground & Background & Foreground & Background \\
\hline \multirow[t]{2}{*}{ IA } & $8.31(1)^{d}$ & $1.75(1)$ & $3.79(2)$ & $4.18(1)$ & $1.38(2)$ & $1.06(1)$ \\
\hline & $8.14(1)$ & $1.73(1)$ & $3.80(2)$ & $4.33(1)$ & & \\
\hline$\| A^{\theta, f}$ & $9.34(-1)$ & & $4.41(0)$ & & $2.41(0)$ & \\
\hline IIB & $1.35(0)$ & $1.60(-1)$ & $4.75(0)$ & $3.63(-1)$ & $1.61(0)$ & $1.64(-1)$ \\
\hline$\| B^{\ominus, f}$ & $4.91(0)$ & & $1.85(1)$ & & $5.66(0)$ & \\
\hline
\end{tabular}

a See experimental program plan for description of configurations.

${ }^{b}$ Count rate without shadow shield between detector and configuration.

${ }^{\circ}$ Count rate with shadow shield between detector and configuration.

${ }^{d}$ Read: $8.31 \times 10^{\prime}$.

Lead slab $(3.81 \mathrm{~cm})$ between configuration and detector (see Figure 18).

'Detector at $25 \mathrm{~cm}$ behind lead slab. 
Table 18. Bonner ball measurements on centerline at $30 \mathrm{~cm}$ behind a series of configurations (Items IA, IIA-B, IIIA-E, IVA-B, VA-B)

\begin{tabular}{ccccccc}
\hline & \multicolumn{5}{c}{ Bonner ball count rates $\left(\mathrm{s}^{-1} \mathrm{~W}^{-1}\right)$} \\
\cline { 2 - 7 } Configuration $^{2}$ & $\begin{array}{c}\text { 3-inch Diam } \\
\text { Ball }\end{array}$ & $\begin{array}{c}\text { 4-inch Diam } \\
\text { Ball }\end{array}$ & $\begin{array}{c}5 \text {-inch Diam } \\
\text { Ball }\end{array}$ & $\begin{array}{c}\text { 8-inch Diam } \\
\text { Ball }\end{array}$ & $\begin{array}{c}\text { 10-inch Diam } \\
\text { Ball }\end{array}$ & $\begin{array}{c}\text { 12-inch Diam } \\
\text { Ball }\end{array}$ \\
\hline IA & $6.00(2)^{b}$ & $2.09(3)$ & $3.03(3)$ & $2.17(3)$ & $1.14(3)$ & $5.45(2)$ \\
IIA & $1.32(0)$ & $4.14(0)$ & $6.11(0)$ & $5.33(0)$ & $3.32(0)$ & $1.87(0)$ \\
IIB & $6.10(0)$ & $1.82(1)$ & $2.41(1)$ & $1.56(1)$ & $7.55(0)$ & $3.41(0)$ \\
IIIA & $1.41(0)$ & $4.39(0)$ & $6.45(0)$ & $5.63(0)$ & $3.38(0)$ & $1.92(0)$ \\
IIIB & $1.56(0)$ & $4.99(0)$ & $7.25(0)$ & $6.12(0)$ & $3.64(0)$ & $2.01(0)$ \\
IIIC & $6.69(0)$ & $1.94(1)$ & $2.60(1)$ & $1.68(1)$ & $8.16(0)$ & $3.71(0)$ \\
IIID & $8.19(0)$ & $2.31(1)$ & $3.02(1)$ & $1.91(1)$ & $9.07(0)$ & $4.02(0)$ \\
IIIE & $5.44(-1)$ & $1.87(0)$ & $2.71(0)$ & $2.27(0)$ & $1.27(0)$ & $6.71(-1)$ \\
IVA & $1.48(0)$ & $4.67(0)$ & $6.75(0)$ & $5.90(0)$ & $3.53(0)$ & $1.98(0)$ \\
IVB & $6.75(0)$ & $1.98(1)$ & $2.58(1)$ & $1.66(1)$ & $7.97(0)$ & $3.54(0)$ \\
VA & $1.69(0)$ & $5.34(0)$ & $7.67(0)$ & $6.08(0)$ & $3.55(0)$ & $1.97(0)$ \\
VB & $8.34(0)$ & $2.40(1)$ & $3.09(1)$ & $1.82(1)$ & $8.92(0)$ & $3.75(0)$ \\
\hline
\end{tabular}

${ }^{2}$ See experimental program plan in Appendix $A$ for description of configurations.

${ }^{b}$ Read: $6.00 \times 10^{2}$. 
Table 19. Bonner ball measurements on centerline at $150 \mathrm{~cm}$ behind a series of configurations (Items IA, IIA-B, IIIA-E, IVA-B, VA-B)

\begin{tabular}{|c|c|c|c|c|c|c|c|c|c|c|c|c|}
\hline \multirow[b]{3}{*}{ Configuration } & \multicolumn{12}{|c|}{ Bonner ball count rates $\left(s^{-1} W^{-1}\right)$} \\
\hline & \multicolumn{2}{|c|}{ 3-inch Diam ball } & \multicolumn{2}{|c|}{ 4-inch Diam ball } & \multicolumn{2}{|c|}{ 5-Inch Diam ball } & \multicolumn{2}{|c|}{ 8-inch Diam ball } & \multicolumn{2}{|c|}{ 10-inch Diam ball } & \multicolumn{2}{|c|}{ 12-inch Diam ball } \\
\hline & Foreground & Backgrounete & Foreground & Background & Foreground & Background & Foreground & Background & Foreground & Background & Foreground & Background \\
\hline IA & $1.08(2)^{d}$ & $1.88(1)$ & $3.52(2)$ & $4.10(1)$ & $5.02(2)$ & $4.74(1)$ & $3.52(2)$ & $2.44(1)$ & $1.84(2)$ & $1.21(1)$ & $8.82(1)$ & $5.30(0)$ \\
\hline \|A & $3.07^{\prime}(-1)$ & $1.48(-1)$ & $7.70(-1)$ & $2.88(-1)$ & $1.04(0)$ & $3.49(-1)$ & $8.53(-1)$ & $2.70(-1)$ & $5.34(-1)$ & $1.80(-1)$ & $3.27(-1)$ & $1.13(-1)$ \\
\hline IIB & $6.94(-1)$ & $1.77(-1)$ & $1.86(0)$ & $3.43(-1)$ & $2.42(0)$ & $4.04(-1)$ & $1.62(0)$ & $2.95(-1)$ & $8.54(-1)$ & $1.93(-1)$ & $4.27(-1)$ & $1.21(-1)$ \\
\hline IIIA & $3.11(-1)$ & $1.50(-1)$ & $8.02(-1)$ & $2.93(-1)$ & $1.09(0)$ & $3.54(-1)$ & $8.86(-1)$ & $2.80(-1)$ & $5.47(-1)$ & $1.85(-1)$ & $3.29(-1)$ & $1.17(-1)$ \\
\hline IIIB & $3.70(-1)$ & $1.41(-1)$ & $9.68(-1)$ & $2.78(-1)$ & $1.29(0)$ & $3.39(-1)$ & $1.00(0)$ & $2.65(-1)$ & $5.97(-1)$ & $1.75(-1)$ & $3.42(-1)$ & $1.11(-1)$ \\
\hline IIIC & $7.71(-1)$ & $1.62(-1)$ & $2.05(0)$ & $3.18(-1)$ & $2.68(0)$ & $3.73(-1)$ & $1.77(0)$ & $2.83(-1)$ & $9.29(-1)$ & $1.82(-1)$ & $4.60(-1)$ & $1.15(-1)$ \\
\hline 1110 & $9.82(-1)$ & $1.50(-1)$ & $2.64(0)$ & $2.97(-1)$ & $3.33(0)$ & $3.47(-1)$ & $2.14(0)$ & $2.62(-1)$ & $1.06(0)$ & $1.70(-1)$ & $5.17(-1)$ & $1.08(-1)$ \\
\hline IIIE & $1.16(-1)$ & $1.87(-2)$ & $3.42(-1)$ & $3.71(-2)$ & $4.62(-1)$ & $4.60(-2)$ & $3.37(-1)$ & $3.68(-2)$ & $1.85(-1)$ & $2.42(-2)$ & $9.87(-2)$ & $1.50(-2)$ \\
\hline IVA & $3.32(-1)$ & $1.47(-1)$ & $8.27(-1)$ & $2.89(-1)$ & $1.11(0)$ & $3.48(-1)$ & $9.15(-1)$ & $2.74(-1)$ & $5.55(-1)$ & $1.82(-1)$ & $3.30(-1)$ & $1.15(-1)$ \\
\hline IVB & $7.87(-1)$ & $1.72(-1)$ & $2.08(0)$ & $3.27(-1)$ & $2.69(0)$ & $3.79(-1)$ & $1.78(0)$ & $2.78(-1)$ & $9.10(-1)$ & $1.79(-1)$ & $4.50(-1)$ & $1.09(-1)$ \\
\hline VA & $3.36(-1)$ & $1.46(-1)$ & $8.63(-1)$ & $2.88(-1)$ & $1.18(0)$ & $3.50(-1)$ & $9.34(-1)$ & $2.76(-1)$ & $5.69(-1)$ & $1.82(-1)$ & $3.29(-1)$ & $1.13(-1)$ \\
\hline VB & $8.74(-1)$ & $1.78(-1)$ & $2.30(0)$ & $3.42(-1)$ & $2.96(0)$ & $4.00(-1)$ & $1.87(0)$ & $2.91(-1)$ & $9.76(-1)$ & $1.93(-1)$ & $4.67(-1)$ & $1.17(-1)$ \\
\hline
\end{tabular}

${ }^{8}$ See experimental program plan in Appendix $A$ for description of configurations. ${ }^{b}$ Count rate without shadow shield between detector and configuration.

${ }^{\circ}$ Count rate with shadow shield between detector and configuration.

${ }^{d}$ Read: $1.08 \times 10^{2}$. 
Table 20. 3-Inch Bonner ball horizontal traverses through midplane at $30 \mathrm{~cm}$ behind a series of configurations (ttems IA IIA-B, IIA-E, INA-B, VA-B)

\begin{tabular}{|c|c|c|c|c|c|c|c|c|c|c|c|c|}
\hline \multirow[b]{2}{*}{$\begin{array}{c}\text { Distance from } \\
\text { centerfine (cm) }\end{array}$} & \multicolumn{12}{|c|}{ Bonner ball count rate $\left(s^{-1} W^{-1}\right)$} \\
\hline & Item $\mid A^{a}$ & Item $\| A^{a}$ & Hem $11 \mathrm{~B}^{\mathrm{a}}$ & Item $\|: A^{a}$ & Item $\| \mathrm{B}^{\mathrm{a}}$ & Item $I I C^{\alpha}$ & Item $I I D^{2}$ & Item $\| E^{2}$ & Item IVA & Item IVB ${ }^{a}$ & Item VA & Item VB \\
\hline $96.2 \mathrm{~s}$ & $1.18(2)^{b}$ & & & & & & & & & & & \\
\hline 86.2 & $1.61(2)$ & & & & & & & & & & & \\
\hline 80 & & $5.29(-1)$ & $8.64(-1)$ & $5.44(-1)$ & $5.10(-1)$ & $9.32(-1)$ & $9.41(-1)$ & $8.80(-2)$ & $5.36(-1)$ & $9.19(-1)$ & $5.42(-1)$ & \\
\hline 76.2 & $2.12(2)$ & & & & & & & & & & & \\
\hline 70 & & & & & & & & $1.18(-1)$ & & & & $1.22(0)$ \\
\hline 66.2 & $2.80(2)$ & & & & & & & & & & & \\
\hline 60 & & $8.24(-1)$ & $1.55(0)$ & $8.34(-1)$ & $8.15(-1)$ & $1.67(0)$ & $1.70(0)$ & $1.58(-1)$ & $8.40(-1)$ & $1.65(0)$ & $8.33(-1)$ & $1.62(0)$ \\
\hline 56.2 & $3.42(2)$ & & & & & & & & & & & \\
\hline 50 & & & . & & & & & $2.08(-1)$ & & & & $2.21(0)$ \\
\hline 46.2 & $4.12(2)$ & & & & & & & & & & & \\
\hline 40 & & $1.09(0)$ & $2.81(0)$ & $1.09(0)$ & . $\quad 1.09(0)$ & $3.07(0)$ & $3.27(0)$ & $2.69(-1)$ & $1.11(0)$ & $3.03(0)$ & $1.09(0)$ & $3.02(0)$ \\
\hline 36.2 & $4.84(2)$ & & & & & & & & & & & \\
\hline 30 & & $1.19(0)$ & $3.85(0)$ & $1.19(0)$ & $1.24(0)$ & $4.16(0)$ & $4.64(0)$ & $3.54(-1)$ & $1.23(0)$ & $4.11(0)$ & $1.19(0)$ & $4.21(0)$ \\
\hline 27 & & & & & $1.32(0)$ & & & & & & & \\
\hline 26.2 & 5.39 (2) & & & & & & & & & & & \\
\hline 25 & & $1.22(0)$ & $4.38(0)$ & $1.24(0)$ & $1.35(0)$ & $4.76(0)$ & $5.46(0)$ & & $1.28(0)$ & $4.71(0)$ & $1.24(0)$ & $4.84(0)$ \\
\hline 24.2 & & & & & $1.35(0)$ & & & & & & & \\
\hline 23.5 & & & & & $1.34(0)$ & & & & & & & \\
\hline 22.5 & & & & & $1.35(0)$ & & & & & & & \\
\hline 20 & & $1.25(0)$ & $4.99(0)$ & $1.26(0)$ & $1.37(0)$ & $5.43(0)$ & $6.24(0)$ & $4.31(-1)$ & $1.31(0)$ & $5.35(0)$ & $1.29(0)$ & $5.59(0)$ \\
\hline 16.6 & & & & & $1.43(0)$ & & & & & & & \\
\hline 16.2 & $5.75(2)$ & & & & & & & & & & & \\
\hline 15 & & $1.31(0)$ & $5.53(0)$ & $1.36(0)$ & & $6.13(0)$ & $7.10(0)$ & & $1.38(0)$ & $5.93(0)$ & $1.36(0)$ & $6.36(0)$ \\
\hline 14 & & & & & $1.49(0)$ & & & & & & & \\
\hline 10.5 & & & & & $1.58(0)$ & & & & & & & \\
\hline 10 & & $1.34(0)$ & $5.98(0)$ & $1.44(0)$ & & $6.65(0)$ & $7.97(0)$ & $5.72(-1)$ & $1.43(0)$ & $6.43(0)$ & $1.51(0)$ & $7.19(0)$ \\
\hline 9.7 & & & & & $1.61(0)$ & & & & & & & \\
\hline 9 & & & & & $1.61(0)$ & & & & & & & \\
\hline 8.3 & & & & $1.46(0)$ & $1.62(0)$ & & & & & & & \\
\hline 7.7 & & & & & $1.62(0)$ & & & & & & & \\
\hline 7 & & & & $1.47(0)$ & $1.60(0)$ & & & & & & & \\
\hline 6.2 & 5.97 (2) & & & & & & & & & & & \\
\hline 6 & & & & & $1.61(0)$ & & & & & & $1.65(0)$ & \\
\hline 5 & & $1.35(0)$ & $6.21(0)$ & & & $6.83(0)$ & $8.14(0)$ & & $1.44(0)$ & $6.71(0)$ & & $7.94(0)$ \\
\hline 3 & & & & & $1.54(0)$ & & & & & & $1.71(0)$ & \\
\hline 2.2 & & & & & & & & & & & & $8.12(0)$ \\
\hline
\end{tabular}


Table 20. (Continued)

\begin{tabular}{|c|c|c|c|c|c|c|c|c|c|c|c|c|}
\hline \multirow[b]{2}{*}{$\begin{array}{l}\text { Distance from } \\
\text { centerline (cm) }\end{array}$} & \multicolumn{12}{|c|}{ Bonner ball count rate $\left(s^{-1} W^{-1}\right)$} \\
\hline & Item $\mathbb{A}^{\mathrm{a}}$ & Item $\| A^{a}$ & Item $118^{a}$ & Item IIIA & Hem $\| I B^{a}$ & Item $I I C^{a}$ & Item $\| D^{a}$ & Item $\| E^{a}$ & Item IVA ${ }^{a}$ & Item IVB ${ }^{a}$ & Item VA & Item $V B^{a}$ \\
\hline 0 & $6.11(2)$ & $1.34(0)$ & $6.30(0)$ & $1.42(0)$ & $1.55(0)$ & $6.81(0)$ & $8.15(0)$ & $5.45(-1)$ & $1.47(0)$ & $6.87(0)$ & $1.71(0)$ & $8.08(0)$ \\
\hline 2.2 & & & & & & & & & & & & 8.06 \\
\hline 3 & & & & & $1.54(0)$ & & & & & & $1.66(0)$ & \\
\hline 5 & & $1.32(0)$ & $6.18(0)$ & $1.45(0)$ & & $6.80(0)$ & $8.16(0)$ & & $1.46(0)$ & $6.73(0)$ & & $7.95(0)$ \\
\hline 6 & & & & & $1.57(0)$ & & & & & & $1.61(0)$ & \\
\hline 6.2 & $6.01(2)$ & & & & & & & . & & & & \\
\hline 7.7 & & & & & $1.61(0)$ & & & 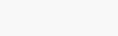 & & & & \\
\hline 9.7 & & & & & $1.59(0)$ & & & & & & & \\
\hline 10 & & $1.31(0)$ & $5.91(0)$ & $1.43(0)$ & & $6.58(0)$ & $7.86(0)$ & $5.73(-1)$ & $1.40(0)$ & $6.36(0)$ & $1.46(0)$ & $7.25(0)$ \\
\hline 14 & & & & & $1.44(0)$ & & & & & & & \\
\hline 15 & & $1.26(0)$ & $5.48(0)$ & $1.34(0)$ & & $5.98(0)$ & $6.96(0)$ & & $1.34(0)$ & $5.81(0)$ & $1.33(0)$ & $6.42(0)$ \\
\hline 16.2 & $5.87(2)$ & & & & & & & & & & & \\
\hline 18 & & & & & $1.36(0)$ & & & & & & & \\
\hline 20 & & $1.19(0)$ & $4.93(0)$ & $1.25(0)$ & & $5.28(0)$ & $6.06(0)$ & $4.41(-1)$ & $1.27(0)$ & $5.20(0)$ & $1.23(0)$ & $5.59(0)$ \\
\hline 22 & & & & & $1.33(0)$ & & & & & & & \\
\hline 25 & & $1.17(0)$ & $4.33(0)$ & $1.21(0)$ & $1.32(0)$ & $4.63(0)$ & $5.30(0)$ & & $1.22(0)$ & $4.54(0)$ & $1.19(0)$ & $4.83(0)$ \\
\hline 26.2 & $5.60(2)$ & & & & & & & & & & & \\
\hline 30 & & $\cdot 1.12(0)$ & $3.78(0)$ & $1.17(0)$ & $1.18(0)$ & $3.97(0)$ & $4.49(0)$ & $3.63(-1)$ & $1.17(0)$ & $4.02(0)$ & $1.12(0)$ & $4.16(0)$ \\
\hline 36.2 & $4.88(2)$ & & & & & & & & & & & \\
\hline 40 & & $1.00(0)$ & $2.74(0)$ & $1.05(0)$ & $1.02(0)$ & $2.91(0)$ & $3.13(0)$ & $2.74(-1)$ & $1.06(0)$ & $2.91(0)$ & $1.00(0)$ & $2.96(0)$ \\
\hline 46.2 & 4.27 (2) & & & & & & & & & & & \\
\hline 50 & & & & $2.12(0)$ & & & $2.20(0)$ & $2.14(-1)$ & & & & $2.12(0)$ \\
\hline 56.2 & $3.52(2)$ & & & & & & & & & & & \\
\hline 60 & & $7.31(-1)$ & $1.46(0)$ & $7.72(-1)$ & $7.34 \cdot(-1)$ & $1.53(0)$ & & & $7.61(-1)$ & $1.53(0)$ & $7.33(-1)$ & $1.55(0)$ \\
\hline 66.2 & $2.95(2)$ & & & & & & & & & & & \\
\hline 70 & & & & & & & $1.16(0)$ & & & & & $1.12(0)$ \\
\hline 76.2 & $2.32(2)$ & & & & & & & & & & & \\
\hline 80 & & $4.56(-1)$ & $8.03(-1)$ & $4.78(-1)$ & $4.52(-1)$ & $8.39(-1)$ & & & $4.69(-1)$ & $8.35(-1)$ & $4.60(-1)$ & \\
\hline 86.2 & $1.73(2)$ & & & & & & & & & & & \\
\hline $96.2 \mathrm{~N}$ & $1.24(2)$ & & & & & & & & & & & \\
\hline
\end{tabular}

${ }^{2}$ See experimental program plan in Appendix A for description of experiments.

${ }^{b}$ Read: $1.18 \times 10^{2}$. 
Table 21. 5-Inch Bonner ball horizontal traverses through midplane at $30 \mathrm{~cm}$ behind a series of configurations (Items IA, IIA-B, \|IA-E, NA-B, VA-B)

\begin{tabular}{|c|c|c|c|c|c|c|c|c|c|c|c|c|}
\hline \multirow[b]{2}{*}{$\begin{array}{l}\text { Distance from } \\
\text { centerline (cm) }\end{array}$} & \multicolumn{12}{|c|}{ Bonner ball count rate $\left(s^{-1} W^{-1}\right)$} \\
\hline & $\operatorname{Item} \mid A^{a}$ & Item $\| A^{a}$ & Item $\| B^{a}$ & Hem IIIA & Item IIIB ${ }^{a}$ & Item IIIC ${ }^{a}$ & Item $\| 1 D^{\alpha}$ & Item IIIE & Item IVA & Hem IVB ${ }^{a}$ & Item $V A^{a}$ & Item VB \\
\hline $96.2 \mathrm{~s}$ & $5.15(2)^{b}$ & & & & & & & & & & & \\
\hline 86.2 & 7.26 (2) & & & & & & & & & & & \\
\hline 80 & & $1.47(0)$ & $2.58(0)$ & $1.44(0)$ & $1.40(0)$ & $2.67(0)$ & $2.69(0)$ & $2.87(-1)$ & $1.47(0)$ & $2.71(0)$ & $1.40(0)$ & $2.58(0)$ \\
\hline 76.2 & $1.04(3)$ & & & & & & & & & & & \\
\hline 70 & & & & & $1.84(0)$ & & & $3.95(-1)$ & & & & \\
\hline 66.2 & $1.30(3)$ & & & & & & & & & & & \\
\hline 60 & & $2.40(0)$ & $4.90(0)$ & $2.37(0)$ & $2.33(0)$ & $5.02(0)$ & $5.15(0)$ & $5.44(-1)$ & $2.43(0)$ & $5.15(0)$ & $2.34(0)$ & $4.96(0)$ \\
\hline 56.2 & $1.68(3)$ & & & & & & & & & & & \\
\hline 50 & & & & & $2.98(0)$ & & $7.40(0)$ & $7.58(-1)$ & & & & $7.01(0)$ \\
\hline 46.2 & 2.01 (3) & & & & & & & & & & & \\
\hline 40 & & $3.64(0)$ & $1.01(1)$ & $3.63(0)$ & $3.78(0)$ & $1.03(1)$ & $1.09(1)$ & $1.08(0)$ & $3.78(0)$ & $1.06(1)$ & $3.61(0)$ & $1.02(1)$ \\
\hline 36.2 & $2.34(3)$ & & & & & & & & & & & \\
\hline 30 & & $4.41(0)$ & $1.42(1)$ & $4.46(0)$ & $4.83(0)$ & 1.49 (1) & $1.61(1)$ & $1.56(0)$ & $4.65(0)$ & $1.52(1)$ & $4.39(0)$ & 1.48 (1) \\
\hline 26.2 & $2.69(3)$ & & & & & & & & & & & \\
\hline 25 & & $4.78(0)$ & $1.66(1)$ & $4.91(0)$ & & $1.73(1)$ & $1.91(1)$ & & $5.10(0)$ & $1.76(1)$ & $4.89(0)$ & $1.75(1)$ \\
\hline 20 & & $5.18(0)$ & $1.88(1)$ & $5.31(0)$ & $6.01(0)$ & $2.01(1)$ & $2.23(1)$ & $2.08(0)$ & $5.54(0)$ & $2.03(1)$ & $5.34(0)$ & $2.02(1)$ \\
\hline 16.6 & & & & & $6.40(0)$ & & & & & & & \\
\hline 16.2 & $2.94(3)$ & & & & & & & & & & & \\
\hline 15 & & $5.59(0)$ & $2.10(1)$ & $5.81(0)$ & $6.57(0)$ & $2.26(1)$ & $2.55(1)$ & & $6.01(0)$ & $2.26(1)$ & $5.84(0)$ & $2.33(1)$ \\
\hline 10 & & $6.03(0)$ & 2.29 (1) & $6.37(0)$ & $7.37(0)$ & 2.47 (1) & $2.84(1)$ & $2.74(0)$ & $6.54(0)$ & $2.48(1)$ & $6.65(0)$ & $2.64(1)$ \\
\hline 7.5 & & & & $6.56(0)$ & & & & & & & & \\
\hline 6.2 & $3.13(3)$ & & & & & & & & & & & \\
\hline 5 & & $6.11(0)$ & $2.38(1)$ & $6.64(0)$ & $7.45(0)$ & $2.60(1)$ & 2.98 (1) & & $6.80(0)$ & $2.63(1)$ & $7.42(0)$ & $2.87(1)$ \\
\hline 2.5 & & & & $6.56(0)$ & & & & & & & & \\
\hline 0 & $3.03(3)$ & $6.09(0)$ & $2.41(1)$ & $6.47(0)$ & $7.29(0)$ & $2.60(1)$ & 2.98 (1) & $2.67(0)$ & $6.83(0)$ & $2.65(1)$ & $7.68(0)$ & 2.95 (1) \\
\hline 5 & & $6.11(0)$ & $2.37^{\prime}(1)$ & $6.41(0)$ & $7.44(0)$ & 2.61 (1) & $2.98(1)$ & & $6.75(0)$ & $2.60(1)$ & $7.40(0)$ & $2.87(1)$ \\
\hline 6.2 & $3.04(3)$ & & & & & & & & & & & \\
\hline 8.3 & & & & & $7.30(0)$ & & & & & & & \\
\hline 10 & & $5.91(0)$ & $2.25(1)$ & $6.26(0)$ & $7.19(0)$ & $2.51(1)$ & $2.87(1)$ & $2.72(0)$ & $6.42(0)$ & $2.46(1)$ & $6.64(0)$ & $2.64(1)$ \\
\hline 15 & & $5.47(0)$ & $2.07(1)$ & $5.75(0)$ & $6.46(0)$ & $2.26(1)$ & $2.55(1)$ & & $5.92(0)$ & $2.23(1)$ & $5.81(0)$ & $2.33(1)$ \\
\hline 16.2 & $3.04(3)$ & & & & & & & & & & & \\
\hline 16.6 & & & & & $6.17(0)$ & & & & & & & \\
\hline 20 & & $5.01(0)$ & $1.84(1)$ & $5.32(0)$ & $5.81(0)$ & $2.01(1)$ & $2.22(1)$ & $2.06(0)$ & $5.41(0)$ & $1.99(1)$ & $5.27(0)$ & $2.02(1)$ \\
\hline 25 & & $4.61(0)$ & $1.59(1)$ & $4.80(0)$ & & $1.75(1)$ & $1.92(1)$ & & $4.90(0)$ & $1.73(1)$ & $4.79(0)$ & $1.73(1)$ \\
\hline 26.2 & $2.63(3)$ & & & & & & & & & & & \\
\hline 30 & & $4.21(0)$ & $1.36(1)$ & $4.37(0)$ & $4.64(0)$ & $1.48(1)$ & $1.61(1)$ & $1.53(0)$ & $4.45(0)$ & $1.46(1)$ & $4.27(0)$ & $1.45(1)$ \\
\hline
\end{tabular}




\begin{tabular}{|c|c|c|c|c|c|c|c|c|c|c|c|c|}
\hline \multicolumn{13}{|c|}{ Table 21. (Continued) } \\
\hline \multirow[b]{2}{*}{$\begin{array}{l}\text { Distance from } \\
\text { conterline }(\mathrm{cm})\end{array}$} & \multicolumn{12}{|c|}{ Bonner ball count rate $\left(s^{-1} W^{-1}\right)$} \\
\hline & Item $\mathbb{A}^{Q}$ & Item $\| A^{8}$ & Item $11 B^{a}$ & Item $I 11 A^{a}$ & Item $\| B^{a}$ & Item IIIC & Hem $\| I D^{a}$ & Item $\| E^{a}$ & Item IVA ${ }^{a}$ & Item $\mathrm{IVB}^{\mathrm{a}}$ & Item $V A^{a}$ & Item VB \\
\hline 36.2 & $2.41(3)$ & & & & & & & & & & & \\
\hline 40 & & $3.35(0)$ & $9.43(0)$ & $3.46(0)$ & $3.58(0)$ & $1.03(1)$ & $1.08(1)$ & $1.06(0)$ & $3.56(0)$ & $1.01(1)$ & $3.45(0)$ & $9.92(0)$ \\
\hline 45 & & & & & & & & $8.91(-1)$ & & & & \\
\hline 46.2 & $2.04(3)$ & & & & & & & & & & & \\
\hline 50 & & & & & & & $7.13(0)$ & & & & & $6.74(0)$ \\
\hline 56.2 & $1.69(3)$ & & & & & & & & & & & \\
\hline 60 & & $2.13(0)$ & $4.50(0)$ & $2.18(0)$ & $2.20(0)$ & $4.82(0)$ & & & $2.22(0)$ & $4.80(0)$ & $2.18(0)$ & \\
\hline 66.2 & $1.38(3)$ & & & & & & & & & & & \\
\hline 70 & & & & & & & $3.46(0)$ & & & & & $3.31(0)$ \\
\hline 76.2 & $1.05(3)$ & & & & & & & & & & & \\
\hline 80 & & $1.26(0)$ & $2.31(0)$ & $1.30(0)$ & $1.24(0)$ & $2.45(0)$ & & & $1.30(0)$ & $2.44(0)$ & $1.29(0)$ & \\
\hline 86.2 & 7.43 (2) & & & & & & & & & & & \\
\hline $96.2 \mathrm{~N}$ & $5.31(2)$ & & & & & & & & & & & \\
\hline
\end{tabular}

${ }^{a}$ See experimental program plan in Appendix A for description of experiments.

${ }^{b}$ Read: $5.15 \times 10^{2}$. 
Table 22. 8-Inch Bonner ball horizontal traverses through midplane at $30 \mathrm{~cm}$ behind a series of configurations (ttems IA, IIA-B, IIAA-E, NA-B, VA-B)

\begin{tabular}{|c|c|c|c|c|c|c|c|c|c|c|c|c|}
\hline \multirow[b]{2}{*}{$\begin{array}{c}\text { Distance from } \\
\text { centerline (cm) }\end{array}$} & \multicolumn{12}{|c|}{ Bonner ball count rate $\left(s^{-1} W^{-1}\right)$} \\
\hline & $\operatorname{Item} \mid A^{a^{*}}$ & $\|$ tem $\| A^{a}$ & Hem $\| B^{a}$ & Item $\| \mathrm{A}^{\mathrm{a}}$ & Item $111 B^{a}$ & Hem $\| C^{a}$ & Hem $1110^{a}$ & Hem $\Perp E^{a}$ & Item IVA & Item IVB & Item $V A^{2}$ & Item VB $B^{a}$ \\
\hline $96.2 \mathrm{~s}$ & $1.74(2)^{b}$ & & & & & & & & & & & \\
\hline 86.2 & $2.46(2)$ & & & & & & & & & & & \\
\hline 80 & & $1.15(0)$ & $1.76(0)$ & $1.19(0)$ & $1.16(0)$ & $1.78(0)$ & $1.91(0)$ & $2.37(-1)$ & $1.19(0)$ & $1.85(0)$ & $1.15(0)$ & $1.77(0)$ \\
\hline 76.2 & $3.69(2)$ & & & & & & & & & & & \\
\hline 70 & & & & & & & & $3.25(-1)$ & & & & \\
\hline 66.2 & $4.77(2)$ & & & & & & & & & & & \\
\hline 60 & & $1.93(0)$ & $3.29(0)$ & $1.98(0)$ & $1.96(0)$ & $3.32(0)$ & $3.60(0)$ & $4.43(-1)$ & $2.01(0)$ & $3.48(0)$ & $1.92(0)$ & $3.36(0)$ \\
\hline 56.2 & $6.03(2)$ & & & & & & & & & & & \\
\hline 50 & & & r & & & & & $6.25(-1)$ & & & & $4.66(0)$ \\
\hline 46.2 & $7.38(2)$ & & & & & & & & & & & \\
\hline 40 & & $2.98(0)$ & $6.50(0)$ & $3.09(0)$ & $3.18(0)$ & $6.62(0)$ & $7.41(0)$ & $8.80(-1)$ & $3.14(0)$ & $6.86(0)$ & $2.99(0)$ & $6.62(0)$ \\
\hline 36.2 & $8.91(2)$ & & & & & & & & & & & \\
\hline 30 & & $3.70(0)$ & $9.14(0)$ & $3.84(0)$ & $4.05(0)$ & $9.27(0)$ & $1.07(1)$ & $1.26(0)$ & $3.95(0)$ & $9.68(0)$ & $3.71(0)$ & $9.42(0)$ \\
\hline 26.2 & $1.00(3)$ & $\cdot$ & & & & & & & & & & \\
\hline 25 & & $4.05(0)$ & $1.07(1)$ & $4.22(0)$ & & $1.09(1)$ & $1.27(1)$ & & $4.35(0)$ & $1.12(1)$ & $4.09(0)$ & $1.10(1)$ \\
\hline 20 & & $4.39(0)$ & $1.21(1)$ & $4.64(0)$ & $5.04(0)$ & $1.25(1)$ & $1.47(1)$ & $1.70(0)$ & $4.76(0)$ & $1.28(1)$ & $4.54(0)$ & $1.28(1)$ \\
\hline 16.2 & $t .14(3)$ & & & & & & & & & & & \\
\hline 15 & & $4.76(0)$ & $1.35(1)$ & $5.04(0)$ & & $1.40(1)$ & $1.66(1)$ & & $5.17(0)$ & $1.42(1)$ & $4.96(0)$ & $1.46(1)$ \\
\hline 10 & & $5.04(0)$ & $1.47(1)$ & $5.38(0)$ & $5.95(0)$ & $1.53(1)$ & $1.81(1)$ & $2.13(0)$ & $5.53(0)$ & $1.54(1)$ & $5.43(0)$ & $1.61(1)$ \\
\hline 6.2 & $1.15(3)$ & & & & & & & & & & & \\
\hline 5 & & $5.17(0)$ & 1.54 (1) & $5.57(0)$ & $6.13(0)$ & $1.60(1)$ & $1.90(1)$ & & $5.75(0)$ & $1.62(1)$ & $5.82(0)$ & $1.75(1)$ \\
\hline 0 & $1.17(3)$ & $5.19(0)$ & $1.57(1)$ & $5.65(0)$ & $6.18(0)$ & $1.63(1)$ & $1.93(1)$ & $2.27(0)$ & $5.86(0)$ & $1.65(1)$ & $5.96(0)$ & $1.81(1)$ \\
\hline 5 & & $5.12(0)$ & $1.55(1)$ & $5.54(0)$ & $6.07(0)$ & $1.61(1)$ & $1.90(1)$ & & $5.73(0)$ & $1.61(1)$ & $5.77(0)$ & $1.77(1)$ \\
\hline 6.2 & $1.14(3)$ & & & & & & & & & & & \\
\hline 10 & & $4.96(0)$ & $1.48(1)$ & $5.34(0)$ & $5.80(0)$ & $1.53(1)$ & $1.79(1)$ & $2.14(0)$ & $5.44(0)$ & $1.52(1)$ & $5.37(0)$ & $1.65(1)$ \\
\hline 15 & & $4.67(0)$ & 1.37 (1) & $4.97(0)$ & & $1.42(1)$ & $1.63(1)$ & & $5.10(0)$ & 1.41 (1) & $4.92(0)$ & $1.50(1)$ \\
\hline 16.2 & $1.10(3)$ & & & & & & & & & & & \\
\hline 20 & & $4.29(0)$ & $1.23(1)$ & $4.51(0)$ & $4.90(0)$ & $1.27(1)$ & $1.43(1)$ & $1.74(0)$ & $4.65(0)$ & $1.26(1)$ & $4.44(0)$ & $1.32(1)$ \\
\hline 25 & & $3.94(0)$ & $1.08(t)$ & $4.10(0)$ & & $1.11(1)$ & $1.24(1)$ & & $4.24(0)$ & $1.10(1)$ & $4.02(0)$ & $1.15(1)$ \\
\hline 26.2 & 9.99 (2) & & & & & & & & & & & \\
\hline 30 & & $3.53(0)$ & $9.33(0)$ & $3.72(0)$ & $3.85(0)$ & $9.48(0)$ & $1.04(1)$ & $1.29(0)$ & $3.80(0)$ & $9.38(0)$ & $3.61(0)$ & $9.63(0)$ \\
\hline 36.2 & 9.09 (2) & & & & & & & & & & & \\
\hline 40 & & $2.79(0)$ & $6.54(0)$ & $2.94(0)$ & $2.95(0)$ & $6.63(0)$ & $7.11(0)$ & $9.19(-1)$ & $3.02(0)$ & $6.60(0)$ & $2.86(0)$ & $6.73(0)$ \\
\hline 46.2 & $7.75(2)$ & & & & & & & & & & & \\
\hline 50 & & & & & & & $4.80(0)$ & $6.43(-1)$ & & & & $4.59(0)$ \\
\hline 56.2 & $6.12(2)$ & & & & & & & & & & & \\
\hline
\end{tabular}


Table 22. (Continued)

Bonner ball count rate $\left(s^{-1} W^{-1}\right)$

\begin{tabular}{|c|c|c|c|c|c|c|c|c|c|c|c|c|}
\hline $\begin{array}{l}\text { Distance from } \\
\text { centerline (cm) }\end{array}$ & Item $\mid A^{a^{\star}}$ & Item $\| A^{a}$ & Item $\| B^{a}$ & Mem IIIA & Item $\| 1 B^{a}$ & Item III & Hem $\| D^{A}$ & Item $\| E^{a}$ & Item IVA & Hem $I V B^{a}$ & Item $V A^{a}$ & Item VB \\
\hline 60 & & $1.73(0)$ & $3.21(0)$ & $1.82(0)$ & $1.78(0)$ & $3.24(0)$ & & & $1.83(0)$ & $3.20(0)$ & $1.77(0)$ & \\
\hline 66.2 & 4.85 (2) & & & & & & & & & & & \\
\hline 70 & & & & & & & $2.39(0)$ & & & & & $2.30(0)$ \\
\hline 76.2 & 3.69 (2) & & & & & & & & & & & \\
\hline 80 & & $1.02(0)$ & $1.68(0)$ & $1.04(0)$ & $1.02(0)$ & $1.68(0)$ & & & $1.07(0)$ & $1.65(0)$ & $1.02(0)$ & \\
\hline 86.2 & $2.65(2)$ & & & & . & & & . & & & & \\
\hline $96.2 \mathrm{~N}$ & 1.77 (2) & & & & & & & & & & & \\
\hline
\end{tabular}

${ }^{a}$ See experimental program plan in Appendix $\mathrm{A}$ for description of experiments.

${ }^{b}$ Read: $1.74 \times 10^{2}$

"The data in Item IA was obtained using the 10-in BB by mistake and the error was not noted until compilation of the results. 
Table 23. Fast neutron fiuxes ( $>0.8 \mathrm{MeV}$ ) on centerline

at $25 \mathrm{~cm}$ behind the lead slab

( $32.6 \mathrm{~cm}$ behind axial shield)

(Item IIA): Run 7895.5

\begin{tabular}{|c|c|c|c|c|c|}
\hline $\begin{array}{c}\text { Neutron } \\
\text { Energy } \\
\text { (MeV) }\end{array}$ & $\begin{array}{l}\text { Flux (neutrons } \\
\text { Lower } \\
\text { Limit }\end{array}$ & $\begin{array}{c}\left.\mathrm{cm}^{-2} \mathrm{MeV}^{-1} \mathrm{~kW}^{-1} \mathrm{~s}^{-1}\right) \\
\text { Upper } \\
\text { Limit }\end{array}$ & $\begin{array}{l}\text { Neutron } \\
\text { Energy } \\
\text { (MeV) }\end{array}$ & $\begin{array}{l}\text { Flux (neutrons } \mathrm{cm}^{-2} \\
\text { Lower } \\
\text { Limit }\end{array}$ & \\
\hline $\begin{array}{l}8.11 E-01 \\
9.07 E-01 \\
1.01 E+00 \\
1.11 E+00 \\
1.20 E+00 \\
1.31 E+00 \\
1.41 E+00 \\
1.51 E+00 \\
1.61 E+00 \\
1.71 E+00 \\
1.81 E+00 \\
1.93 E+00 \\
2.10 E+00 \\
2.30 E+00 \\
2.50 E+00 \\
2.70 E+00 \\
2.90 E+00 \\
3.10 E+00 \\
3.30 E+00 \\
3.50 E+00 \\
3.71 E+00 \\
3.91 E+00 \\
4.15 E+00 \\
4.45 E+00 \\
4.75 E+00 \\
5.04 E+00 \\
5.34 E+00 \\
5.64 E+00\end{array}$ & $\begin{array}{l}9.27 \mathrm{E}+02 \\
9.89 \mathrm{E}+02 \\
8.48 \mathrm{E}+02 \\
6.75 \mathrm{E}+02 \\
5.49 \mathrm{E}+02 \\
4.69 \mathrm{E}+02 \\
4.32 \mathrm{E}+02 \\
4.12 \mathrm{E}+02 \\
3.92 \mathrm{E}+02 \\
3.69 \mathrm{E}+02 \\
3.49 \mathrm{E}+02 \\
3.35 \mathrm{E}+02 \\
3.14 \mathrm{E}+02 \\
2.69 \mathrm{E}+02 \\
2.12 \mathrm{E}+02 \\
1.59 \mathrm{E}+02 \\
1.23 \mathrm{E}+02 \\
9.71 \mathrm{E}+01 \\
7.98 \mathrm{E}+01 \\
6.92 \mathrm{E}+01 \\
6.32 \mathrm{E}+01 \\
5.88 \mathrm{E}+01 \\
5.37 \mathrm{E}+01 \\
4.68 \mathrm{E}+01 \\
4.02 \mathrm{E}+01 \\
3.43 \mathrm{E}+01 \\
2.89 \mathrm{E}+01 \\
2.46 \mathrm{E}+01\end{array}$ & $\begin{array}{l}9.48 E+00 \\
9.97 E+02 \\
8.54 E+02 \\
6.81 E+02 \\
5.55 E+02 \\
4.75 E+02 \\
4.37 E+02 \\
4.18 E+02 \\
3.97 E+02 \\
3.73 E+02 \\
3.53 E+02 \\
3.39 E+02 \\
3.17 E+02 \\
2.72 E+02 \\
2.14 E+02 \\
1.62 E+02 \\
1.26 E+02 \\
9.99 E+01 \\
8.20 E+01 \\
7.17 E+01 \\
6.51 E+01 \\
6.06 E+01 \\
5.53 E+01 \\
4.81 E+01 \\
4.14 E+01 \\
3.54 E+01 \\
3.00 E+01 \\
2.58 E+01\end{array}$ & $\begin{array}{l}5.94 \mathrm{E}+00 \\
6.25 \mathrm{E}+00 \\
6.55 \mathrm{E}+00 \\
6.84 \mathrm{E}+00 \\
7.24 \mathrm{E}+00 \\
7.74 \mathrm{E}+00 \\
8.24 \mathrm{E}+00 \\
8.76 \mathrm{E}+00 \\
9.26 \mathrm{E}+00 \\
9.74 \mathrm{E}+00 \\
1.03 \mathrm{E}+01 \\
1.08 \mathrm{E}+01 \\
1.12 \mathrm{E}+01 \\
1.18 \mathrm{E}+01 \\
1.24 \mathrm{E}+01 \\
1.32 \mathrm{E}+01 \\
1.40 \mathrm{E}+01 \\
1.48 \mathrm{E}+01 \\
1.56 \mathrm{E}+01 \\
1.65 \mathrm{E}+01 \\
1.75 \mathrm{E}+01 \\
1.85 \mathrm{E}+01 \\
1.95 \mathrm{E}+01 \\
2.05 \mathrm{E}+01 \\
2.16 \mathrm{E}+01 \\
2.26 \mathrm{E}+01 \\
2.35 \mathrm{E}+01\end{array}$ & $\begin{array}{l}2.09 \mathrm{E}+01 \\
1.73 \mathrm{E}+01 \\
1.46 \mathrm{E}+01 \\
1.27 \mathrm{E}+01 \\
1.04 \mathrm{E}+01 \\
7.56 \mathrm{E}+00 \\
5.56 \mathrm{E}+00 \\
4.07 \mathrm{E}+00 \\
3.04 \mathrm{E}+00 \\
2.60 \mathrm{E}+00 \\
2.12 \mathrm{E}+00 \\
1.44 \mathrm{E}+00 \\
9.57 \mathrm{E}-01 \\
6.94 \mathrm{E}-01 \\
4.66 \mathrm{E}-01 \\
2.52 \mathrm{E}-01 \\
1.57 \mathrm{E}-01 \\
9.10 \mathrm{E}-02 \\
4.82 \mathrm{E}-02 \\
2.55 \mathrm{E}-02 \\
1.58 \mathrm{E}-02 \\
1.48 \mathrm{E}-02 \\
-8.07 \mathrm{E}-04 \\
-1.88 \mathrm{E}-02 \\
-2.12 \mathrm{E}-02 \\
-1.15 \mathrm{E}-02 \\
-7.25 \mathrm{E}-03\end{array}$ & \\
\hline $\begin{array}{c}\mathrm{E1} \\
(\mathrm{MeV})\end{array}$ & & $\begin{array}{c}\text { E2 } \\
(\mathrm{MeV})\end{array}$ & $\begin{array}{c}\text { Integral } \\
\text { neutrons } \mathrm{cm}^{-2} \mathrm{MeV}^{1} \mathrm{~kW}^{-1} \mathrm{~s}^{-1}\end{array}$ & $\begin{array}{c}\text { Error } \\
\text { neutrons } \mathrm{cm}^{-2} \mathrm{MeV}^{1} \mathrm{~kW}^{1} \mathrm{~s}^{\mathrm{s}}\end{array}$ & \\
\hline $\begin{array}{l}0.811 \\
1.000 \\
1.200 \\
1.600 \\
2.000 \\
3.000 \\
4.000 \\
6.000 \\
8.000 \\
10.000 \\
12.000 \\
16.000 \\
3.000 \\
1.500 \\
3.000\end{array}$ & & $\begin{array}{l}1.000 \\
1.200 \\
1.600 \\
2.000 \\
3.000 \\
4.000 \\
6.000 \\
8.000 \\
10.000 \\
12.000 \\
16.000 \\
20.000 \\
10.000 \\
15.000 \\
12.000\end{array}$ & $\begin{array}{c}1.82 E+02 \\
1.39 E+02 \\
1.80 E+02 \\
1.43 E+02 \\
2.16 E+02 \\
7.49 E+01 \\
7.40 E+01 \\
2.51 E+01 \\
8.05 E+00 \\
2.79 E+00 \\
9.77 E-01 \\
1.17 E-01 \\
1.82 E+02 \\
5.86 E+02 \\
1.85 E+02\end{array}$ & $\begin{array}{c}9.70 E-01 \\
6.06 E-01 \\
1.10 E+00 \\
8.38 E-01 \\
1.51 E+00 \\
1.12 E+00 \\
1.22 E+00 \\
8.17 E-01 \\
4.09 E-01 \\
1.83 E-01 \\
1.59 E-01 \\
5.95 E-02 \\
3.58 E+00 \\
6.49 E+00 \\
3.76 E+00\end{array}$ & \\
\hline
\end{tabular}


Table 24. Neutron fluxes ( $50 \mathrm{keV}$ to $1.4 \mathrm{MeV}$ ) on centerline at $25 \mathrm{~cm}$ behind lead slab ( $32.6 \mathrm{~cm}$ behind axial shield)

(Item IIA)

\begin{tabular}{|c|c|c|c|c|}
\hline$N$ & Energ & andary & $\begin{array}{c}\text { Flux } \\
\text { (neutrons } \mathrm{cm}^{-2} \mathrm{MeV}^{-1} \mathrm{~kW}^{-1} \mathrm{~s}^{-1} \text { ) }\end{array}$ & $\begin{array}{c}\text { Error } \\
(\%)\end{array}$ \\
\hline \multicolumn{5}{|c|}{$\underline{\text { RUN 1570.B }}$} \\
\hline 1 & 0.0332 & 0.0394 & $1.91 E+04$ & 2.02 \\
\hline 2 & 0.0394 & 0.0456 & $1.04 E+04$ & 4.04 \\
\hline 3 & 0.0456 & 0.0533 & $8.62 E+03$ & 4.28 \\
\hline 4 & 0.0533 & 0.0641 & 7.77E + 03 & 3.68 \\
\hline 5 & 0.0641 & 0.0750 & $8.02 E+03$ & 4.02 \\
\hline 6 & 0.0750 & 0.0873 & $5.93 E+03$ & 5.18 \\
\hline 7 & 0.0873 & 0.1028 & $3.43 E+03$ & 7.78 \\
\hline 8 & 0.1028 & 0.1213 & $4.22 E+03$ & 5.84 \\
\hline 9 & 0.1213 & 0.1430 & $4.53 E+03$ & 5.13 \\
\hline 10 & 0.1430 & 0.1677 & $3.13 E+03$ & 7.14 \\
\hline 11 & 0.1677 & 0.1986 & $2.90 E+03$ & 6.60 \\
\hline \multicolumn{5}{|c|}{$\underline{\text { RUN 1568.B }}$} \\
\hline 1 & 0.1436 & 0.1680 & $3.02 E+03$ & 2.40 \\
\hline 2 & 0.1680 & 0.1986 & $2.63 E+03$ & 2.53 \\
\hline 3 & 0.1986 & 0.2353 & $2.45 E+03$ & 2.59 \\
\hline 4 & 0.2353 & 0.2719 & $2.56 E+03$ & 2.85 \\
\hline 5 & 0.2719 & 0.3208 & $2.33 E+03$ & 2.59 \\
\hline 6 & 0.3208 & 0.3819 & $1.82 E+03$ & 2.95 \\
\hline 7 & 0.3819 & 0.4491 & $1.50 E+03$ & 3.74 \\
\hline 8 & 0.4491 & 0.5224 & $1.58 E+03$ & 3.68 \\
\hline 9 & 0.5224 & 0.6202 & $1.65 E+03$ & 2.75 \\
\hline 10 & 0.6202 & 0.7302 & $1.36 E+03$ & 3.22 \\
\hline \multicolumn{5}{|c|}{ RUN 1568.A } \\
\hline 1 & 0.5216 & 0.6204 & $1.49 E+03$ & 1.65 \\
\hline 2 & 0.6204 & 0.7302 & $1.34 E+03$ & 1.82 \\
\hline 3 & 0.7302 & 0.8510 & $1.15 E+03$ & 2.09 \\
\hline 4 & 0.8510 & 1.0047 & $9.05 E+02$ & 2.16 \\
\hline 5 & 1.0047 & 1.1804 & $6.40 E+02$ & 2.82 \\
\hline 6 & 1.1804 & 1.4000 & $4.49 E+02$ & 3.31 \\
\hline
\end{tabular}


Table 25. Hornyak button traverses through horizontal midplane behind a series of configurations (items IIA-B, IIIA-E, INA-B, VA-B) ${ }^{a}$

\begin{tabular}{|c|c|c|c|c|c|c|c|c|c|c|c|c|}
\hline \multirow[b]{2}{*}{$\begin{array}{l}\text { Distance from } \\
\text { centerline } \\
\text { (cm) }\end{array}$} & \multicolumn{12}{|c|}{ Neutron Dose Rate (erg/g'h'w) } \\
\hline & $\operatorname{ttem} \| A^{c}$ & Item $\| B^{c}$ & Item IIIA & Item IIII $\mathrm{B}^{\mathrm{C}}$ & Item iler & Item IIIIf & Item IIIE $E^{d}$ & Item IWE de & Item IVAc & Item $I V E^{c}$ & Item VAc & Item $\mathrm{VP}$ \\
\hline $80 \mathrm{~s}$ & $4.13(-4)^{f}$ & & $4.57(-4)$ & $4.14(-4)$ & $4.28(-4)$ & $4.25(-4)$ & $5.61(-5)$ & $7.04(-5)$ & $4.88(-4)$ & $4.40(-4)$ & $4.15(-4)$ & \\
\hline 70 & & & & & & & $8.35(-5)$ & & & & & $7.15(-4)$ \\
\hline 60 & $9.68(-4)$ & $1.01(-3)$ & $1.05(-3)$ & $9.93(-4)$ & $9.88(-4)$ & $1.00(-3)$ & $1.28(-4)$ & $1.58(-4)$ & $1.14(-3)$ & $9.97(-4)$ & $9.90(-4)$ & \\
\hline 50 & & $1.24(-3)$ & & & & & $1.83(-4)$ & & & $1.23(-3)$ & & $1.27(-3)$ \\
\hline 40 & $1.45(-3)$ & $1.36(-3)$ & $1.54(-3)$ & $1.47(-3)$ & $1.33(-3)$ & $1.34(-3)$ & $2.72(-4)$ & $2.81(-4)$ & $1.67(-3)$ & $1.36(-3)$ & $1.49(-3)$ & $1.41(-3)$ \\
\hline 30 & $1.68(-3)$ & $1.32(-3)$ & $1.78(-3)$ & $1.66(-3)$ & $1.27(-3)$ & $1.30(-3)$ & $3.99(-4)$ & & $1.87(-3)$ & $1.33(-3)$ & $1.67(-3)$ & $1.35(-3)$ \\
\hline 27.8 & & & & & & & & $4.92(-4)$ & & & & \\
\hline 27.5 & & & & & & & & & & & & $1.33(-3)$ \\
\hline 27 & & & & $1.88(-3)$ & & $1.35(-3)$ & $4.75(-4)$ & & & $1.37(-3)$ & & \\
\hline 25 & $1.96(-3)$ & $1.37(-3)$ & $2.13(-3)$ & $2.12(-3)$ & $1.36(-3)$ & $1.40(-3)$ & $5.65(-4)$ & & $2.23(-3)$ & $1.43(-3)$ & $2.01(-3)$ & $1.42(-3)$ \\
\hline 24.2 & & & & $2.20(-3)$ & & $1.40(-3)$ & & & & & & \\
\hline 23.5 & & & & $2.29(-3)$ & & $1.42(-3)$ & & & & & & \\
\hline 23 & & & & & & & $6.91(-4)$ & & & & & \\
\hline 22.5 & & & & $2.34(-3)$ & & $1.39(-3)$ & & & & & & \\
\hline 20 & $2.30(-3)$ & $1.40(-3)$ & $2.51(-3)$ & $2.56(-3)$ & $1.40(-3)$ & $1.40(-3)$ & $7.65(-4)$ & & $2.64(-3)$ & $1.55(-3)$ & $2.33(-3)$ & $1,46(-3)$ \\
\hline 16.6 & & & & & & & & $8.54(-4)$ & & & & $1.57(-3)$ \\
\hline 16.5 & & & & $2.79(-3)$ & & $1.42(-3)$ & & & & & & \\
\hline 16 & & & & & & & $8.70(-4)$ & & & & & \\
\hline 15 & $2.57(-3)$ & $1.49(-3)$ & $2.86(-3)$ & & $1.49(-3)$ & & & & $2.98(-3)$ & $1.64(-3)$ & $2.63(-3)$ & \\
\hline 14 & & & & $2.94(-3)$ & & $1.52(-3)$ & & & & & & \\
\hline 12 & & & & & & & & & & & & $1.65(-3)$ \\
\hline 10.5 & & & & $3.07(-3)$ & & $1.68(-3)$ & & & & & & \\
\hline 10 & $2.81(-3)$ & $1.56(-3)$ & $3.16(-3)$ & & $1.58(-3)$ & & & & $3.30(-3)$ & $1.79(-3)$ & $2.91(-3)$ & \\
\hline 9.7 & & & & $3.12(-3)$ & & $1.74(-3)$ & $9.70(-4)$ & & & & & \\
\hline 9 & & & & $3.08(-3)$ & & $1.73(-3)$ & & & & & & \\
\hline 8.9 & & & & & & & $9.86(-4)$ & $1.02(-3)$ & & & & \\
\hline 8.8 & $2.97(-3)$ & & & & & & & & & & & \\
\hline 8.4 & & & & $3.19(-3)$ & & $1.76(-3)$ & & & & & & \\
\hline 8.3 & $2.98(-3)$ & $1.60(-3)$ & $3.31(-3)$ & & $1.62(-3)$ & & $1.02(-3)$ & $1.03(-3)$ & $3.49(-3)$ & $1.82(-3)$ & $3.08(-3)$ & $1.74(-3)$ \\
\hline 7.7 & $2.99(-3)$ & & $3,39(-3)$ & $3.15(-3)$ & $1.65(-3)$ & $1.79(-3)$ & & $1.02(-3)$ & $3.60(-3)$ & & $3.15(-3)$ & \\
\hline 7 & & & $3.44(-3)$ & $3.16 \cdot(-3)$ & $1.65(-3)$ & $1.71(-3)$ & & & $3.62(-3)$ & $1.84(-3)$ & & \\
\hline 6 & & & $3.47(-3)$ & $3.15(-3)$ & $1.61(-3)$ & $1.73(-3)$ & & & $3.65(-3)$ & $1.82(-3)$ & $3.23(-3)$ & $1.75(-3)$ \\
\hline 5 & $2.93(-3)$ & $1.62(-3)$ & & & & & & & & $1.82(-3)$ & & \\
\hline 4.5 & & & & & & & & & & & & $1.81(-3)$ \\
\hline 4 & & & $3.52(-3)$ & & & & & & $3.82(-3)$ & $1.84(-3)$ & $3.31(-3)$ & \\
\hline 3 & & & & $3.26(-3)$ & $1.55(-3)$ & $1.66(-3)$ & & & & & & $1.84(-3)$ \\
\hline 2.5 & & & & & & & & & $3.86(-3)$ & & & \\
\hline
\end{tabular}




\begin{tabular}{|c|c|c|c|c|c|c|c|c|c|c|c|c|}
\hline \multirow[b]{2}{*}{$\begin{array}{c}\text { Distance from } \\
\text { centerline } \\
\text { (cm) }\end{array}$} & \multicolumn{12}{|c|}{ Neutron Dose Rate (erg/g $\left.h^{\top} w\right)$} \\
\hline & Item IIA ${ }^{C}$ & Item IIBC & Item IIIA $A^{c}$ & Item $\| I I B^{c}$ & Item $\| I^{C}$ & Item $\| D^{c}$ & Item IIIE $E^{d}$ & Item IIIE $E^{d e}$ & Item $\mathbf{N A}^{c}$ & Item IVB ${ }^{C}$ & Item VA & Item $V g^{c}$ \\
\hline 2.2 & & & & & & & & & & & & $1.88(-3)$ \\
\hline $\begin{array}{l}2 \\
0 \\
2\end{array}$ & $2.97(-3)$ & $1.62(-3)$ & $3.55(-3)$ & $3.28(-3)$ & $1.55(-3)$ & $1.63(-3)$ & $1.10(-3)$ & $1.09(-3)$ & $3.85(-3)$ & $1.85(-3)$ & $\begin{array}{l}3.34(-3) \\
3.33(-3) \\
3.32(-3)\end{array}$ & $1.88(-3)$ \\
\hline 2.2 & & & & & & & & & & & & $1.85(-3)$ \\
\hline 2.5 & & & & & & & & & $3.91(-3)$ & & & \\
\hline 3 & & & & $3.20(-3)$ & $1.58(-3)$ & $1.68(-3)$ & & & & & & \\
\hline 4 & & & $3.50(-3)$ & & & & & & $3.80(-3)$ & $1.82(-3)$ & $3.24(-3)$ & \\
\hline 4.5 & & & & & & & & & & & & $1.82(-3)$ \\
\hline 5 & $2.94(-3)$ & $1.60(-3)$ & & & & & & & & & & 1 AR (-3) \\
\hline $\begin{array}{l}6 \\
7\end{array}$ & & & $\begin{array}{l}3.43(-3) \\
3.35(-3)\end{array}$ & $\begin{array}{l}3.16(-3) \\
3.14(-3)\end{array}$ & $\begin{array}{l}1.57(-3) \\
1.60(-3)\end{array}$ & $\begin{array}{l}1,69(-3) \\
1.77(-3)\end{array}$ & & $1.06(-3)$ & $\begin{array}{l}3.72(-3) \\
3.64(-3)\end{array}$ & $1.83(-3)$ & $3.23(-3)$ & $1.68(-3)$ \\
\hline 7.7 & & & $3.34(-3)$ & $3.05(-3)$ & $1.59(-3)$ & $1.74(-3)$ & & $1.01(-3)$ & $3.42(-3)$ & & $3.17(-3)$ & \\
\hline 8.3 & $2.96(-3)$ & $1.59(-3)$ & $3.32(-3)$ & & $1.58(-3)$ & & & $1.00(-3)$ & $3.55(-3)$ & $1.79(-3)$ & $3.09(-3)$ & $1.68(-3)$ \\
\hline 8.4 & & & & $2.99(-3)$ & & $1.72(-3)$ & & & & & & \\
\hline$\theta$ & & & & $2.92(-3)$ & & $1.70(-3)$ & & & & & & \\
\hline 9.7 & & & & $2.92(-3)$ & & $1.72(-3)$ & & & & & & \\
\hline 10 & $2.87(-3)$ & $1.55(-3)$ & $3.13(-3)$ & & $1.58(-3)$ & & $9.71(-4)$ & & $3.36(-3)$ & $1.72(-3)$ & $2.89(-3)$ & \\
\hline $\begin{array}{c}10.5 \\
12\end{array}$ & & & & $2.94(-3)$ & & $1.64(-3)$ & & & & & & $1.56(-3)$ \\
\hline 14 & & & & $2.80(-3)$ & & $1.44(-3)$ & & & & & & \\
\hline 15 & $2.61(-3)$ & $1.44(-3)$ & $2.87(-3)$ & & $1.45(-3)$ & & & & $3.01(-3)$ & $1.58(-3)$ & $2.69(-3)$ & \\
\hline 16.5 & & & & $2.67(-3)$ & & $1.35(-3)$ & & & & & & \\
\hline 16.6 & & & & & & & $8.86(-4)$ & $8.56(-4)$ & & & & $1.41(-3)$ \\
\hline 20 & $2.29(-3)$ & $1.33(-3)$ & $2.49(-3)$ & $2.41(-3)$ & $1.31(-3)$ & $1.29(-3)$ & & & $2.60(-3)$ & $1.44(-3)$ & $2.27(-3)$ & $1.34(-3)$ \\
\hline 22.5 & & & & $2.22(-3)$ & & $1.32(-3)$ & & & & & & \\
\hline 23.5 & & & & $2.12(-3)$ & & $1.36(-3)$ & & & & & & \\
\hline 24.2 & & & & $2.04(-3)$ & & $1.33(-3)$ & & & & & & \\
\hline $\begin{array}{c}24.9 \\
25\end{array}$ & $1.93(-3)$ & $1.24(-3)$ & $2.09(-3)$ & $1.90(-3)$ & $1.21(-3)$ & $1.31(-3)$ & $6.14(-4)$ & $5.85(-4)$ & $2.22(-3)$ & $1.30(-3)$ & $1.90(-3)$ & $1.28(-3)$ \\
\hline 27 & & & & $1.68(-3)$ & & $1.25(-3)$ & & & & & & \\
\hline 27.5 & & & & & & & $4.93(-4)$ & & & & & $1.22(-3)$ \\
\hline 27.8 & & & & & & & & $5.00(-4)$ & & & & \\
\hline 30 & $1.53(-3)$ & $1.12(-3)$ & $1.67(-3)$ & $1.50(-3)$ & $1.12(-3)$ & $1.14(-3)$ & & & $1.77(-3)$ & $1.17(-3)$ & $1.54(-3)$ & $1.14(-3)$ \\
\hline 35 & & $1.19(-3)$ & & & $1.17(-3)$ & & $3.19(-4)$ & $3.57(-4)$ & & & & \\
\hline 40 & $1.29(-3)$ & $1.19(-3)$ & $1.41(-3)$ & $1.26(-3)$ & $1.18(-3)$ & $1.19(-3)$ & & & $1.49(-3)$ & $1.17(-3)$ & $1.29(-3)$ & \\
\hline 45 & & & & & & & $2.23(-4)$ & $2.39(-4)$ & & $105+3$ & & 109 \\
\hline $\begin{array}{l}50 \\
60\end{array}$ & $8.31(-4)$ & $8.39(-4)$ & $9.02(-4)$ & $8.15(-4)$ & $8.35(-4)$ & $8.21(-4)$ & & & $9.48(-4)$ & $\begin{array}{l}1.05(-3) \\
8.33(-4)\end{array}$ & $8.14(-3)$ & $1.08(-3)$ \\
\hline 70 & 336 (-4) & $3.43(-4)$ & $360<-4)$ & $338(-4)$ & $341(-4)$ & $5.77(-4)$ & & & & $3,40(-4)$ & $3.30(-3)$ & \\
\hline
\end{tabular}

${ }^{2}$ See experimental program plan for description of configurations.

${ }^{b}$ Distance from centerline of shield mockup.

${ }^{\circ} D$ ata at $2.37 \mathrm{~cm}$ behind configuration.

${ }^{d}$ Data at $1.85 \mathrm{~cm}$ behind configuration.

${ }^{8}$ Repeat of measurement with different Hornyak button detector.

'Read: $4.13 \times 10-4$. 
Table 26. Fast neutron fluxes ( $>0.8 \mathrm{MeV}$ ) on centerline at $98.3 \mathrm{~cm}$ behind axial shield)

(Item IIB): Run 7889.2

\begin{tabular}{|c|c|c|c|c|c|}
\hline $\begin{array}{c}\text { Neutron } \\
\text { Energy } \\
(\mathrm{MeV})\end{array}$ & \multicolumn{2}{|c|}{ Flux (neutrons $\mathrm{cm}^{-2} \mathrm{MeV}^{-1} \mathrm{~kW}^{-1} \mathrm{~s}^{-1}$ ) } & $\begin{array}{l}\text { Neutron } \\
\text { Energy } \\
\text { (MeV) }\end{array}$ & $\begin{array}{l}\text { Flux (neutrons cm } \\
\text { Lower } \\
\text { Limit }\end{array}$ & \\
\hline $\begin{array}{l}8.11 E-01 \\
9.07 E-01 \\
1.01 E+00 \\
1.11 E+00 \\
1.20 E+00 \\
1.31 E+00 \\
1.41 E+00 \\
1.51 E+00 \\
1.61 E+00 \\
1.71 E+00 \\
1.81 E+00 \\
1.93 E+00 \\
2.10 E+00 \\
2.30 E+00 \\
2.50 E+00 \\
2.70 E+00 \\
2.90 E+00 \\
3.10 E+00 \\
3.30 E+00 \\
3.30 E+00 \\
3.71 E+00 \\
3.91 E+00 \\
4.15 E+00 \\
4.45 E+00 \\
4.75 E+00 \\
5.04 E+00 \\
5.34 E+00 \\
5.64 E+00\end{array}$ & $\begin{array}{l}2.37 \mathrm{E}+02 \\
2.41 \mathrm{E}+02 \\
2.07 \mathrm{E}+02 \\
1.68 \mathrm{E}+02 \\
1.40 \mathrm{E}+02 \\
1.25 \mathrm{E}+02 \\
1.15 \mathrm{E}+02 \\
1.04 \mathrm{E}+02 \\
9.20 \mathrm{E}+01 \\
8.40 \mathrm{E}+01 \\
8.17 \mathrm{E}+01 \\
8.55 \mathrm{E}+01 \\
9.39 \mathrm{E}+01 \\
9.56 \mathrm{E}+01 \\
8.14 \mathrm{E}+01 \\
6.07 \mathrm{E}+01 \\
4.38 \mathrm{E}+01 \\
3.01 \mathrm{E}+01 \\
2.03 \mathrm{E}+01 \\
1.48 \mathrm{E}+01 \\
1.34 \mathrm{E}+01 \\
1.35 \mathrm{E}+01 \\
1.43 \mathrm{E}+01 \\
1.47 \mathrm{E}+01 \\
1.28 \mathrm{E}+01 \\
1.10 \mathrm{E}+01 \\
1.06 \mathrm{E}+01 \\
9.93 \mathrm{E}+00\end{array}$ & $\begin{array}{l}2.50 \mathrm{E}+02 \\
2.47 \mathrm{E}+02 \\
2.12 \mathrm{E}+02 \\
1.73 \mathrm{E}+02 \\
1.44 \mathrm{E}+02 \\
1.30 \mathrm{E}+02 \\
1.20 \mathrm{E}+02 \\
1.08 \mathrm{E}+02 \\
9.60 \mathrm{E}+01 \\
8.78 \mathrm{E}+01 \\
8.54 \mathrm{E}+01 \\
8.91 \mathrm{E}+01 \\
9.74 \mathrm{E}+01 \\
9.87 \mathrm{E}+01 \\
8.39 \mathrm{E}+01 \\
6.30 \mathrm{E}+01 \\
4.60 \mathrm{E}+01 \\
3.24 \mathrm{E}+01 \\
2.22 \mathrm{E}+01 \\
1.70 \mathrm{E}+01 \\
1.51 \mathrm{E}+01 \\
1.50 \mathrm{E}+01 \\
1.57 \mathrm{E}+01 \\
1.59 \mathrm{E}+01 \\
1.39 \mathrm{E}+01 \\
1.20 \mathrm{E}+01 \\
1.16 \mathrm{E}+01 \\
1.10 \mathrm{E}+01\end{array}$ & $\begin{array}{l}5.94 E+00 \\
6.25 E+00 \\
6.55 E+00 \\
6.84 E+00 \\
7.24 E+00 \\
7.74 E+00 \\
8.24 E+00 \\
8.76 E+00 \\
9.26 E+00 \\
9.74 E+00 \\
1.03 E+01 \\
1.08 E+01 \\
1.12 E+01 \\
1.18 E+01 \\
1.24 E+01 \\
1.32 E+01 \\
1.40 E+01 \\
1.48 E+01 \\
1.56 E+01 \\
1.65 E+01 \\
1.75 E+01 \\
1.85 E+01 \\
1.95 E+01 \\
2.05 E+01 \\
2.16 E+01 \\
2.26 E+01 \\
2.35 E+01\end{array}$ & $\begin{array}{l}8.25 E+00 \\
6.44 E+00 \\
5.59 E+00 \\
4.88 E+00 \\
3.79 E+00 \\
2.84 E+00 \\
2.28 E+00 \\
1.85 E+00 \\
1.23 E+00 \\
6.39 E-01 \\
4.66 E-01 \\
6.62 E-01 \\
6.51 E-01 \\
4.38 E-01 \\
2.28 E-01 \\
8.48 E-02 \\
-3.74 E-03 \\
4.04 E-02 \\
3.15 E-02 \\
-4.34 E-04 \\
-1.59 E-02 \\
-2.03 E-02 \\
-1.94 E-02 \\
-3.28 E-02 \\
-3.44 E-02 \\
-1.82 E-02 \\
-1.09 E-02\end{array}$ & $\begin{array}{l}9.1 \\
7.5 \\
6.5 \\
5.5 \\
4.3 \\
3.4 \\
2.8 \\
2.2 \\
1.5 \\
9 . \\
7 . \\
8 . \\
8 . \\
6 . \\
3 . \\
1 . \\
1 . \\
4 . \\
2 . \\
1 . \\
1 . \\
1 . \\
1 . \\
2 .\end{array}$ \\
\hline $\begin{array}{c}\mathrm{E} 1 \\
(\mathrm{MeV})\end{array}$ & & & $\underset{\text { Integral }}{\text { Inteutrons } \mathrm{cm}^{-2} \mathrm{MeV}^{I} \mathrm{~kW}^{1} \mathrm{~s}^{-1}}$ & $\begin{array}{c}\text { Error } \\
\text { neutrons } \mathrm{cm}^{-2} \mathrm{MeV}^{1} \mathrm{~kW}^{-1} \mathrm{~s}\end{array}$ & \\
\hline $\begin{array}{l}0.811 \\
1.000 \\
1.200 \\
1.600 \\
2.000 \\
3.000 \\
4.000 \\
6.000 \\
8.000 \\
10.000 \\
12.000 \\
16.000 \\
3.000 \\
1.500 \\
3.000\end{array}$ & & $\begin{array}{l}000 \\
200 \\
600 \\
000 \\
000 \\
000 \\
000 \\
000 \\
.000 \\
000 \\
000 \\
.000 \\
.000 \\
.000 \\
.000\end{array}$ & $\begin{array}{l}4.51 \mathrm{E}+01 \\
3.49 \mathrm{E}+01 \\
4.73 \mathrm{E}+01 \\
3.47 \mathrm{E}+01 \\
7.63 \mathrm{E}+01 \\
1.94 \mathrm{E}+01 \\
2.48 \mathrm{E}+01 \\
9.90 \mathrm{E}+00 \\
3.42 \mathrm{E}+00 \\
1.35 \mathrm{E}+00 \\
5.25 \mathrm{E}-01 \\
2.33 \mathrm{E}-02 \\
5.75 \mathrm{E}+01 \\
1.80 \mathrm{E}+02 \\
5.88 \mathrm{E}+01\end{array}$ & $\begin{array}{c}6.60 E-01 \\
4.96 E-01 \\
8.86 E-01 \\
7.41 E-01 \\
1.37 E+00 \\
9.65 E-01 \\
1.15 E+00 \\
7.55 E-01 \\
3.98 E-01 \\
2.28 E-01 \\
2.08 E-01 \\
7.77 E-02 \\
3.27 E+00 \\
5.99 E+00 \\
3.49 E+00\end{array}$ & \\
\hline
\end{tabular}


Table 27. Neutron fiuxes ( $50 \mathrm{keV}$ to $1.4 \mathrm{MeV}$ ) on centerline at $98.3 \mathrm{~cm}$ behind behind axial shield (Item IIB) Runs 1563-6.sum, 1564.A, 1564.B

\begin{tabular}{|c|c|c|c|c|}
\hline$N$ & \multicolumn{2}{|c|}{$\begin{array}{l}\text { Energy Boundary } \\
\text { (MeV) }\end{array}$} & $\begin{array}{c}\text { Flux } \\
\text { (neutrons } \mathrm{cm}^{-2} \mathrm{MeV}^{-1} \mathrm{~kW}^{-1} \mathrm{~s}^{-1} \text { ) }\end{array}$ & $\begin{array}{c}\text { Error } \\
(\%)\end{array}$ \\
\hline \multicolumn{5}{|c|}{$\underline{\text { RUN 1564.B }}$} \\
\hline 1 & 0.0333 & 0.0398 & $3.25 E+04$ & 0.85 \\
\hline 2 & 0.0398 & 0.0463 & $1.47 E+04$ & 1.95 \\
\hline 3 & 0.0463 & 0.0544 & $1.05 E+04$ & 2.35 \\
\hline 4 & 0.0544 & 0.0641 & $9.35 E+03$ & 2.38 \\
\hline 5 & 0.0641 & 0.0755 & $1.01 E+04$ & 2.02 \\
\hline 6 & 0.0755 & 0.0885 & $6.99 E+03$ & 2.70 \\
\hline 7 & 0.0885 & 0.1031 & $3.02 E+03$ & 6.06 \\
\hline 8 & 0.1031 & 0.1226 & $4.58 E+03$ & 3.19 \\
\hline 9 & 0.1226 & 0.1437 & $6.80 E+03$ & 2.12 \\
\hline 10 & 0.1437 & 0.1697 & $3.30 E+03$ & 3.59 \\
\hline 11 & 0.1697 & 0.1989 & $2.25 E+03$ & 5.08 \\
\hline 12 & 0.1989 & 0.2346 & $2.09 E+03$ & 4.71 \\
\hline \multicolumn{5}{|c|}{ RUN 1564.A } \\
\hline 1 & 0.1698 & 0.2003 & $2.24 E+03$ & 4.19 \\
\hline 2 & 0.2003 & 0.2346 & $1.85 E+03$ & 4.98 \\
\hline 3 & 0.2346 & 0.2766 & $2.46 E+03$ & 3.24 \\
\hline 4 & 0.2766 & 0.3224 & $2.44 E+03$ & 3.12 \\
\hline 5 & 0.3796 & 0.4483 & $8.37 E+02$ & 6.11 \\
\hline 6 & 0.4483 & 0.5284 & $5.98 E+03$ & 7.77 \\
\hline \multicolumn{5}{|c|}{$\underline{\text { RUN 1563-6.sum }}$} \\
\hline 1 & 0.3759 & 0.4521 & $8.36 E+02$ & 1.41 \\
\hline 2 & 0.4521 & 0.5284 & $6.56 \mathrm{E}+02$ & 2.00 \\
\hline 3 & 0.5284 & 0.6156 & $7.05 E+02$ & 1.73 \\
\hline 4 & 0.6156 & 0.7245 & $5.39 E+02$ & 1.84 \\
\hline 5 & 0.7245 & 0.8553 & $3.39 E+02$ & 2.52 \\
\hline 6 & 0.8553 & 1.0078 & $2.16 E+02$ & 3.60 \\
\hline 7 & 1.0078 & 1.1821 & $1.55 E+02$ & 4.73 \\
\hline 8 & 1.1821 & 1.4000 & $1.16 E+02$ & 5.25 \\
\hline
\end{tabular}


Table 28. Fast neutron fluxes (>0.8 MeV) on centerline at $25 \mathrm{~cm}$ beyond lead ( $36.2 \mathrm{~cm}$ behind axial shield)

(Item IIB): Run 7892.3

\begin{tabular}{|c|c|c|c|c|c|}
\hline $\begin{array}{c}\text { Neutron } \\
\text { Energy } \\
\text { (MeV) }\end{array}$ & $\begin{array}{l}\text { Flux (neutrons } \\
\text { Lower } \\
\text { Limit }\end{array}$ & $\begin{array}{c}\left.\mathrm{cm}^{-2} \mathrm{MeV}^{-1} \mathrm{~kW}^{-1} \mathrm{~s}^{-1}\right) \\
\text { Upper } \\
\text { Limit }\end{array}$ & $\begin{array}{l}\text { Neutron } \\
\text { Energy } \\
\text { (MeV) }\end{array}$ & Flux (neutrons $\mathrm{cm}^{-}$ & ${ }^{2} \mathrm{MeV}$ \\
\hline $\begin{array}{c}8.11 E-01 \\
9.07 E-01 \\
1.01 E+00 \\
1.11 E+00 \\
1.20 E+00 \\
1.31 E+00 \\
1.41 E+00 \\
1.51 E+00 \\
1.61 E+00 \\
1.71 E+00 \\
1.81 E+00 \\
1.93 E+00 \\
2.10 E+00 \\
2.30 E+00 \\
2.50 E+00 \\
2.70 E+00 \\
2.90 E+00 \\
3.10 E+00 \\
3.30 E+00 \\
3.30 E+00 \\
3.71 E+00 \\
3.91 E+00 \\
4.15 E+00 \\
4.45 E+00 \\
4.75 E+00 \\
5.04 E+00 \\
5.34 E+00 \\
5.64 E+00\end{array}$ & $\begin{array}{l}8.62 E+02 \\
8.94 E+02 \\
7.62 E+02 \\
6.08 E+02 \\
4.95 E+02 \\
4.14 E+02 \\
3.58 E+02 \\
3.16 E+02 \\
2.79 E+02 \\
2.48 E+02 \\
2.26 E+02 \\
2.11 E+02 \\
1.99 E+02 \\
1.74 E+02 \\
1.372+01 \\
9.94 E+01 \\
7.11 E+01 \\
5.02 E+01 \\
3.67 E+01 \\
2.94 E+01 \\
2.59 E+01 \\
2.42 E+01 \\
2.30 E+01 \\
2.09 E+01 \\
1.87 E+01 \\
1.69 E+01 \\
1.41 E+01 \\
1.14 E+01\end{array}$ & $\begin{array}{l}8.75 E+02 \\
9.00 E+02 \\
7.68 E+02 \\
6.13 E+02 \\
5.00 E+02 \\
4.18 E+02 \\
3.61 E+02 \\
3.19 E+02 \\
2.82 E+02 \\
2.51 E+02 \\
2.29 E+02 \\
2.14 E+02 \\
2.02 E+02 \\
1.77 E+02 \\
1.39 E+02 \\
1.01 E+02 \\
7.27 E+01 \\
5.19 E+01 \\
3.81 E+01 \\
3.09 E+01 \\
2.71 E+01 \\
2.53 E+01 \\
2.40 E+01 \\
2.17 E+01 \\
1.94 E+01 \\
1.75 E+01 \\
1.48 E+01 \\
1.21 E+01\end{array}$ & $\begin{array}{l}5.94 \mathrm{E}+00 \\
6.25 \mathrm{E}+00 \\
6.55 \mathrm{E}+00 \\
6.84 \mathrm{E}+00 \\
7.24 \mathrm{E}+00 \\
7.74 \mathrm{E}+00 \\
8.24 \mathrm{E}+00 \\
8.76 \mathrm{E}+00 \\
9.26 \mathrm{E}+00 \\
9.74 \mathrm{E}+00 \\
1.03 \mathrm{E}+01 \\
1.08 \mathrm{E}+01 \\
1.12 \mathrm{E}+01 \\
1.18 \mathrm{E}+01 \\
1.24 \mathrm{E}+01 \\
1.32 \mathrm{E}+01 \\
1.40 \mathrm{E}+01 \\
1.48 \mathrm{E}+01 \\
1.56 \mathrm{E}+01 \\
1.65 \mathrm{E}+01 \\
1.75 \mathrm{E}+01 \\
1.85 \mathrm{E}+01 \\
1.95 \mathrm{E}+01 \\
2.05 \mathrm{E}+01 \\
2.16 \mathrm{E}+01 \\
2.26 \mathrm{E}+01 \\
2.35 \mathrm{E}+01\end{array}$ & $\begin{array}{l}9.94 \mathrm{E}+00 \\
8.58 \mathrm{E}+00 \\
7.07 \mathrm{E}+00 \\
5.80 \mathrm{E}+00 \\
4.45 \mathrm{E}+00 \\
3.06 \mathrm{E}+00 \\
2.00 \mathrm{E}+00 \\
1.57 \mathrm{E}+00 \\
1.30 \mathrm{E}+00 \\
9.76 \mathrm{E}-01 \\
5.77 \mathrm{E}-01 \\
3.41 \mathrm{E}-01 \\
3.23 \mathrm{E}-01 \\
3.19 \mathrm{E}-01 \\
2.38 \mathrm{E}-01 \\
1.51 \mathrm{E}-01 \\
8.41 \mathrm{E}-02 \\
3.46 \mathrm{E}-02 \\
-3.90 \mathrm{E}-03 \\
1.50 \mathrm{E}-03 \\
1.07 \mathrm{E}-02 \\
2.61 \mathrm{E}-03 \\
-6.71 \mathrm{E}-03 \\
-6.41 \mathrm{E}-03 \\
-4.79 \mathrm{E}-03 \\
-4.64 \mathrm{E}-03 \\
-5.92 \mathrm{E}-03\end{array}$ & $\begin{array}{l}1.05 \\
9.30 \\
7.67 \\
6.21 \\
4.77 \\
3.43 \\
2.36 \\
1.77 \\
1.48 \\
1.12 \\
7.0 \\
4.5 \\
4.1 \\
4.0 \\
3.1 \\
2.0 \\
1.3 \\
6.8 \\
2.8 \\
2.0 \\
3.2 \\
1.5 \\
3.9 \\
9.7 \\
1.2 \\
6.4 \\
3.8\end{array}$ \\
\hline $\begin{array}{c}\mathrm{E} 1 \\
(\mathrm{MeV})\end{array}$ & & $\begin{array}{c}\mathrm{E} 2 \\
(\mathrm{MeV})\end{array}$ & $\underset{\text { neutrons } \mathrm{cm}^{-2} \mathrm{MeV}^{-1} \mathrm{~kW}^{1} \mathrm{~s}^{-1}}{\text { Integral }}$ & $\begin{array}{c}\text { Error } \\
\text { neutrons } \mathrm{cm}^{-2} \mathrm{MeV}^{1} \mathrm{~kW}^{-1} \mathrm{~s}\end{array}$ & \\
\hline $\begin{array}{l}0.811 \\
1.000 \\
1.200 \\
1.600 \\
2.000 \\
3.000 \\
4.000 \\
6.000 \\
8.000 \\
10.000 \\
12.000 \\
16.000 \\
3.000 \\
1.500 \\
3.000\end{array}$ & & $\begin{array}{l}1.000 \\
1.200 \\
1.600 \\
2.000 \\
3.000 \\
4.000 \\
6.000 \\
8.000 \\
10.000 \\
12.000 \\
16.000 \\
20.000 \\
10.000 \\
15.000 \\
12.000\end{array}$ & $\begin{array}{l}1.65 E+02 \\
1.25 E+02 \\
1.50 E+02 \\
9.40 E+01 \\
1.37 E+02 \\
3.41 E+01 \\
3.42 E+01 \\
1.16 E+01 \\
3.16 E+00 \\
8.93 E-01 \\
5.06 E-01 \\
4.22 E-02 \\
8.30 E+01 \\
3.46 E+02 \\
8.39 E+01\end{array}$ & $\begin{array}{c}6.90 E-01 \\
4.83 E-01 \\
7.50 E-01 \\
5.87 E-01 \\
1.00 E+00 \\
6.75 E-01 \\
7.37 E-01 \\
4.60 E-01 \\
2.15 E-01 \\
1.06 E-01 \\
9.79 E-02 \\
3.32 E-02 \\
2.09 E+00 \\
4.04 E+00 \\
2.20 E+00\end{array}$ & \\
\hline
\end{tabular}


Table 29. Neutron fluxes (50 keV to $1.4 \mathrm{MeV}$ ) on centerline at $25 \mathrm{~cm}$ beyond lead $(36.2 \mathrm{~cm}$ behind axial shield (Item IIB) Runs 1567.A, 1567.B, 1567.C

\begin{tabular}{|c|c|c|c|c|}
\hline $\mathbf{N}$ & \multicolumn{2}{|c|}{$\begin{array}{l}\text { Energy Boundary } \\
\text { (MeV) }\end{array}$} & $\begin{array}{c}\text { Flux } \\
\text { (neutrons } \mathrm{cm}^{-2} \mathrm{MeV}^{-1} \mathrm{~kW}^{-1} \mathrm{~s}^{-1} \text { ) }\end{array}$ & $\begin{array}{c}\text { Error } \\
(\%)\end{array}$ \\
\hline \multicolumn{5}{|c|}{$\underline{\text { RUN } 1567 . C}$} \\
\hline 1 & 0.0389 & 0.0455 & $3.17 E+04$ & 2.32 \\
\hline 2 & 0.0455 & 0.0538 & $3.50 E+04$ & 1.87 \\
\hline 3 & 0.0538 & 0.0637 & $3.77 E+04$ & 1.57 \\
\hline 4 & 0.0637 & 0.0736 & $3.88 E+03$ & 1.66 \\
\hline 5 & 0.0736 & 0.0868 & $2.73 E+04$ & 1.84 \\
\hline 6 & 0.0868 & 0.1034 & $1.46 \mathrm{E}+04$ & 2.94 \\
\hline 7 & 0.1034 & 0.1216 & $2.00 E+04$ & 2.18 \\
\hline 8 & 0.1216 & 0.1414 & $2.33 E+04$ & 1.83 \\
\hline 9 & 0.1414 & 0.1679 & $1.33 E+04$ & 2.40 \\
\hline 10 & 0.1679 & 0.1977 & $1.02 E+04$ & 3.02 \\
\hline 11 & 0.1977 & 0.2324 & $9.42 E+03$ & 2.98 \\
\hline \multicolumn{5}{|c|}{$\underline{\text { RUN 1567.B }}$} \\
\hline 1 & 0.1671 & 0.1978 & $9.93 E+03$ & 1.72 \\
\hline 2 & 0.1978 & 0.2324 & $8.81 E+03$ & 1.90 \\
\hline 3 & 0.2324 & 0.2747 & $1.01 E+04$ & 1.42 \\
\hline 4 & 0.2747 & 0.3246 & $9.70 E+03$ & 1.28 \\
\hline 5 & 0.3246 & 0.3784 & $6.33 E+03$ & 1.89 \\
\hline 6 & 0.3784 & 0.4475 & $3.90 E+03$ & 2.38 \\
\hline 7 & 0.4475 & 0.5244 & $2.88 E+03$ & 3.08 \\
\hline 8 & 0.5244 & 0.6204 & $2.82 E+03$ & 2.49 \\
\hline \multicolumn{5}{|c|}{ RUN 1567.A } \\
\hline 1 & 0.4447 & 0.5216 & $2.94 E+03$ & 1.14 \\
\hline 2 & 0.5216 & 0.6204 & $2.80 E+03$ & 0.94 \\
\hline 3 & 0.6204 & 0.7302 & $1.95 E+03$ & 1.24 \\
\hline 4 & 0.7302 & 0.8510 & $1.25 E+03$ & 1.80 \\
\hline 5 & 0.8510 & 1.0047 & $8.37 E+02$ & 2.11 \\
\hline 6 & 1.0047 & 1.1804 & $5.99 E+02$ & 2.66 \\
\hline 8 & 1.1804 & 1.4000 & $4.13 E+02$ & 3.06 \\
\hline
\end{tabular}


APPENDIX C

FIGURES 


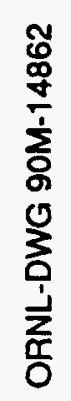

ธ

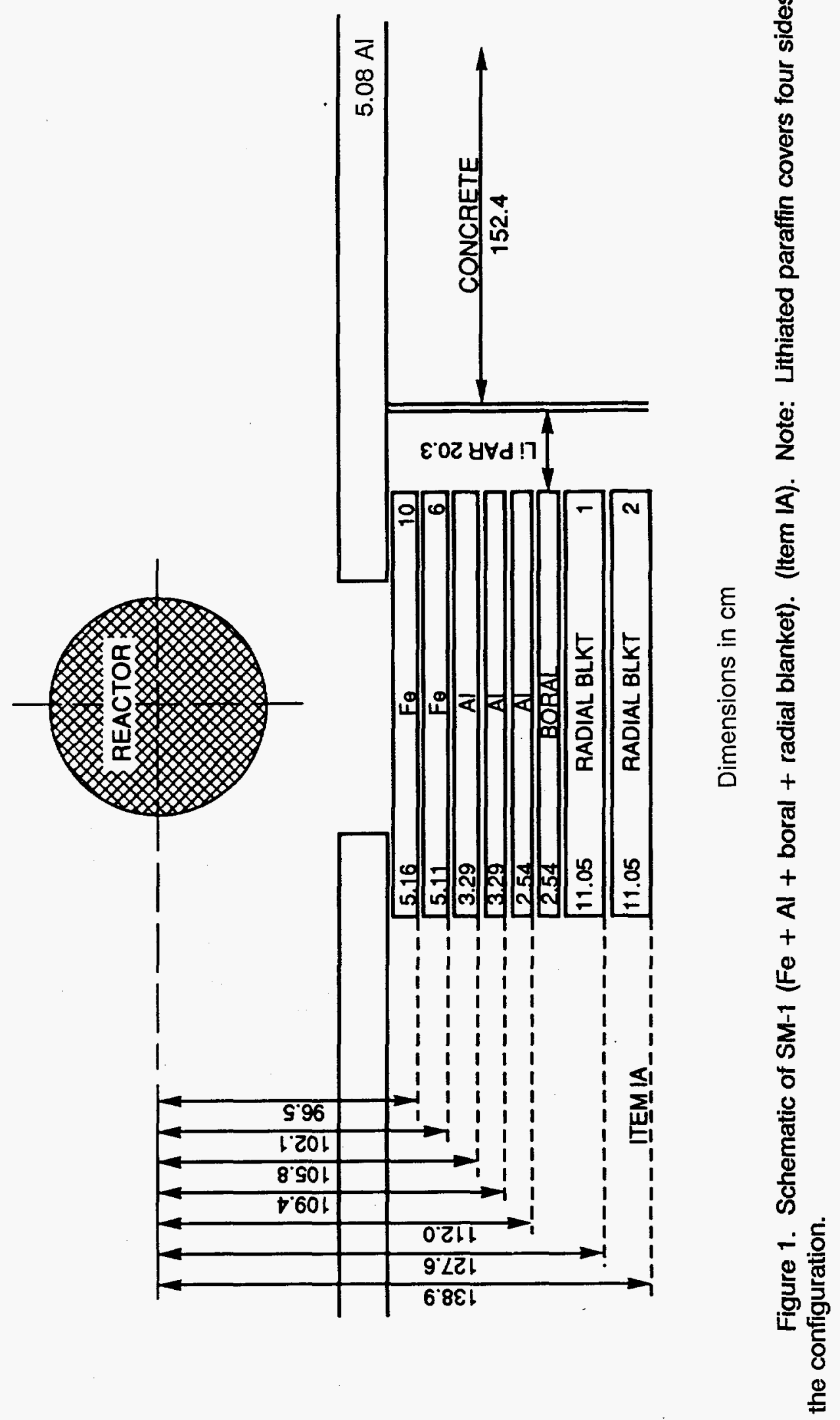



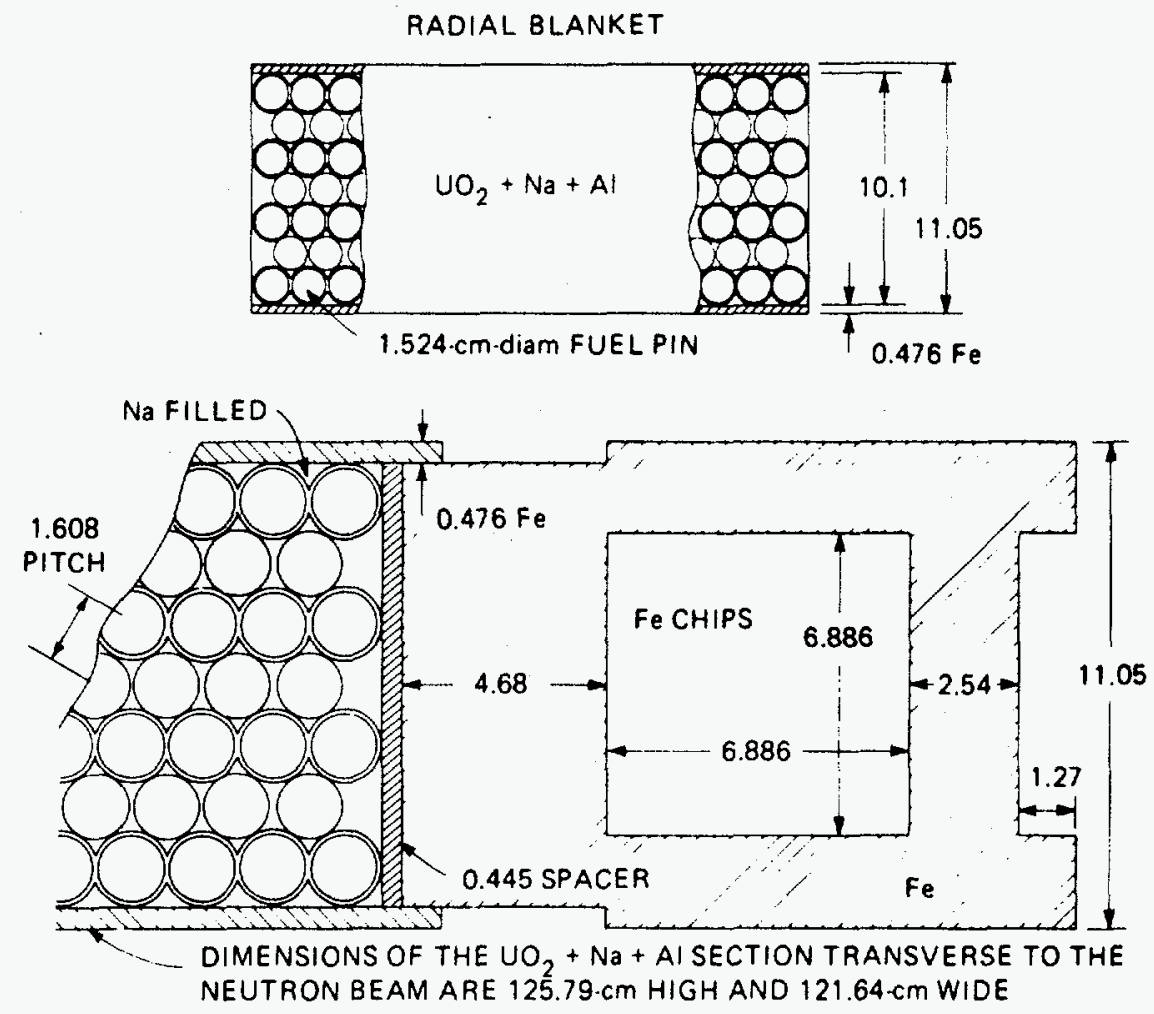

THEORETICAL DENSITY $=10.96 \mathrm{~g} / \mathrm{cc}$

ACTUAL DENSITY $(0.94$ THEO $)=10.28 \mathrm{~g} / \mathrm{cC}$

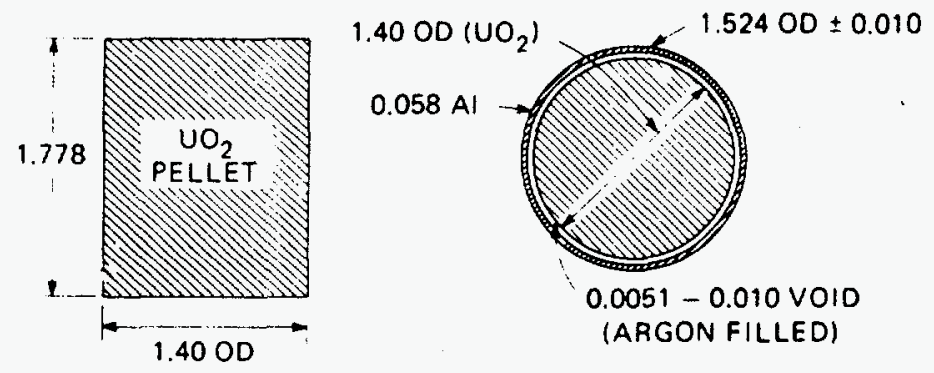

DIMENSIONS IN $\mathrm{cm}$

Figure 2. Schematic of radial blanket slab containing $\mathrm{UO}_{2}$. 


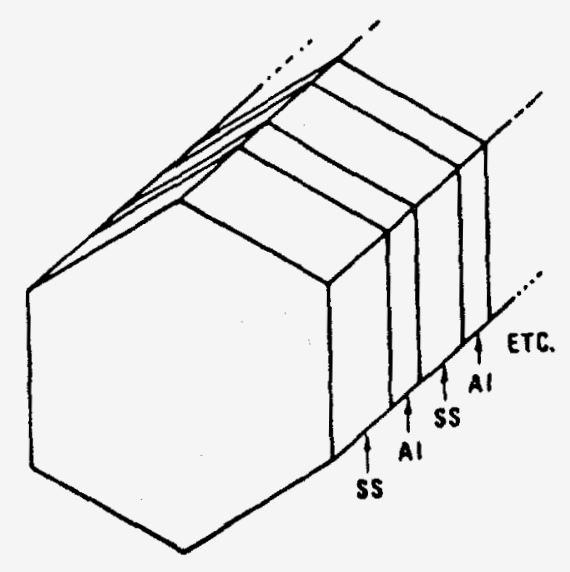

Thickness of Al pieces: $2.136 \mathrm{~cm}$ (6 total)

Thickness of SS pieces: $5.357 \mathrm{~cm}$ (6 total)

Width of assembly (flat surface to flat surface): $15.99 \mathrm{~cm}$

Figure 3. SS homogeneous-type assembly.

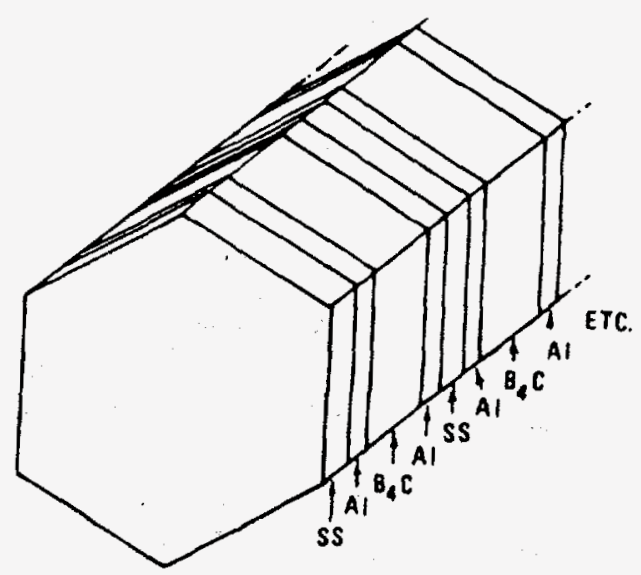

Depth of $\mathrm{B}_{4} \mathrm{C}$ in container: $7.77 \mathrm{~cm}$ (4 total)

Width of $\mathrm{B}_{4} \mathrm{C}: 14.73 \mathrm{~cm}$

End plate thickness: $1.123 \mathrm{~cm}$

Wall thickness of container: $.627 \mathrm{~cm}$

Width of container (flat surface to flat surface: $15.98 \mathrm{~cm}$

Density of $\mathrm{B}_{4} \mathrm{C}: 1.41 \mathrm{~g} / \mathrm{cC}$

Thickness of SS pieces: $1.25 \mathrm{~cm}$ ( 4 total)

Figure 4. $\mathrm{B}_{4} \mathrm{C}$ homogeneous-type assembly. 


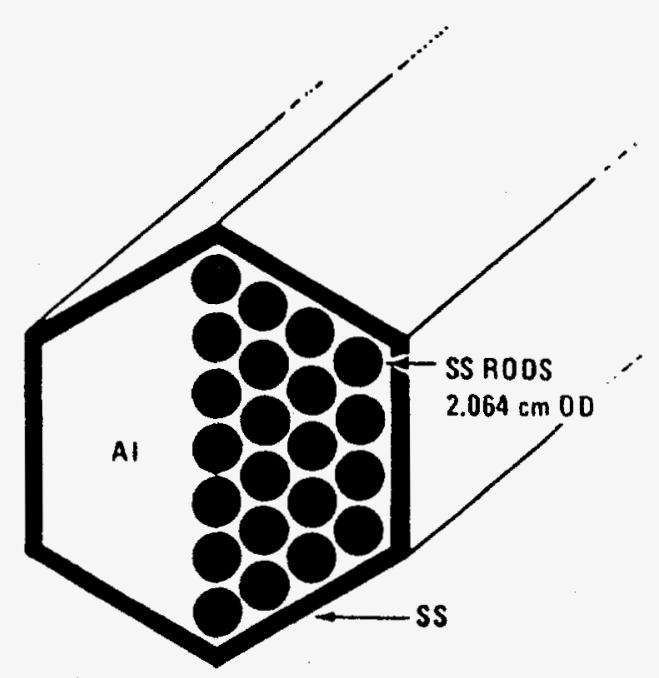

Diam of rod: $2.041 \mathrm{~cm}$

Diam of hole: $2.064 \mathrm{~cm}$

Length of aluminum: $44.97 \mathrm{~cm}$

Thickness of SS wrapper: $.452 \mathrm{~cm}$

Pitch of rods: $2.38 \mathrm{~cm}$

Width of aluminum (flat surface to flat surface): $15.00 \mathrm{~cm}$

Figure 5. SS rod bundle assembly ( 37 rods).

OD of rod: $2.06 \mathrm{~cm}$

ID of rod wall: $1.897 \mathrm{~cm}$

Rod wall thickness: $.0813 \mathrm{~cm}$

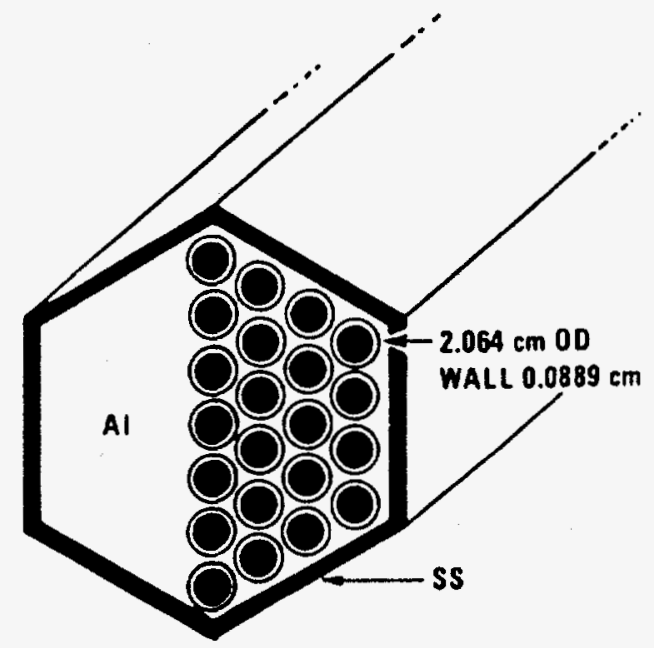

Thickness of rod cap: $.159 \mathrm{~cm}$

Length of $\mathrm{B}_{4} \mathrm{C}$ in rod: $44.7 \mathrm{~cm}$

Volume of $\mathrm{B}_{4} \mathrm{C}$ rod: $126.28 \mathrm{cc}$

Average density of $\mathrm{B}_{4} \mathrm{C}: 1.30 \mathrm{~g} / \mathrm{cc}$

Thickness of SS wrapper: $.465 \mathrm{~cm}$

Rod pitch: $2.38 \mathrm{~cm}$

Width of Al (flat surface to flat surface): $15.00 \mathrm{~cm}$

Width of assembly (flat surface to flat surface): $15.93 \mathrm{~cm}$

Figure 6. $\mathrm{B}_{4} \mathrm{C}$ rod bundle assembly ( 37 tubes). 


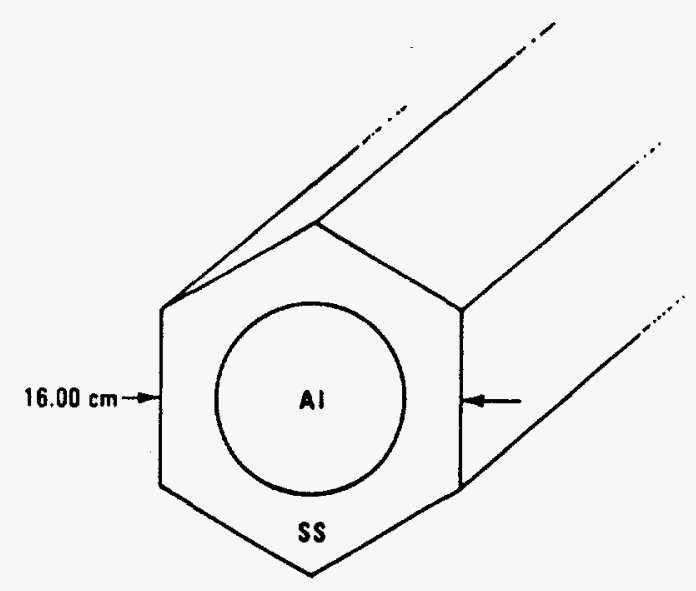

Diam of aluminum cylinder: $8.96 \mathrm{~cm}$

Length of aluminum cylinder: $44.97 \mathrm{~cm}$

Width of assembly (flat surface to flat surface): $16.03 \mathrm{~cm}$

Figure 7. SS central Na channel,

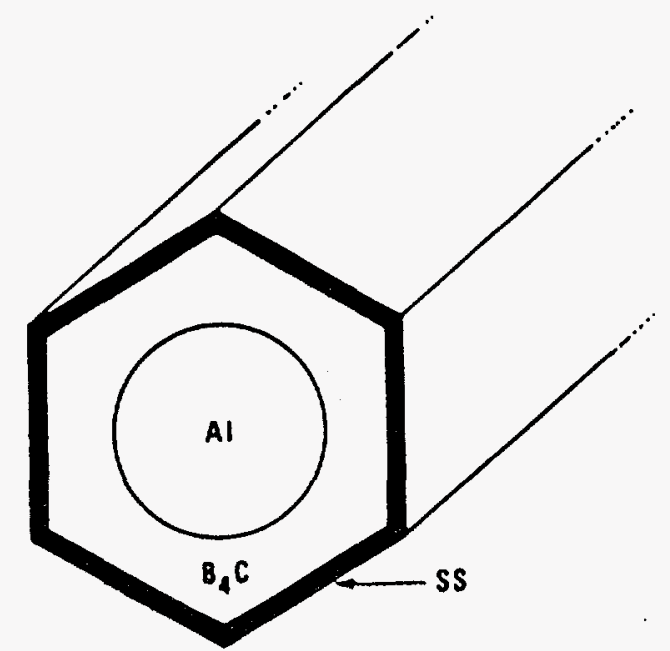

Diam of Al cylinder: $8.96 \mathrm{~cm}$

Length of Al cylinder: $43.412 \mathrm{~cm}$

Width of hexagon (flat surface to flat surface): $15.99 \mathrm{~cm}$

Thickness of SS wrapper: $.452 \mathrm{~cm}$

Length of SS wrapper: $45 \mathrm{~cm}$

Volume of $\mathrm{B}_{4} \mathrm{C}: 5760.1 \mathrm{cc}$

Density of $\mathrm{B}_{4} \mathrm{C}: 1.39 \mathrm{~g} / \mathrm{cC}$

Thickness of $\mathrm{Al}$ covers over end of $\mathrm{B}_{4} \mathrm{C}: .794 \mathrm{~cm}$

Figure 8. $\mathrm{B}_{4} \mathrm{C}$ central $\mathrm{Na}$ channel. 


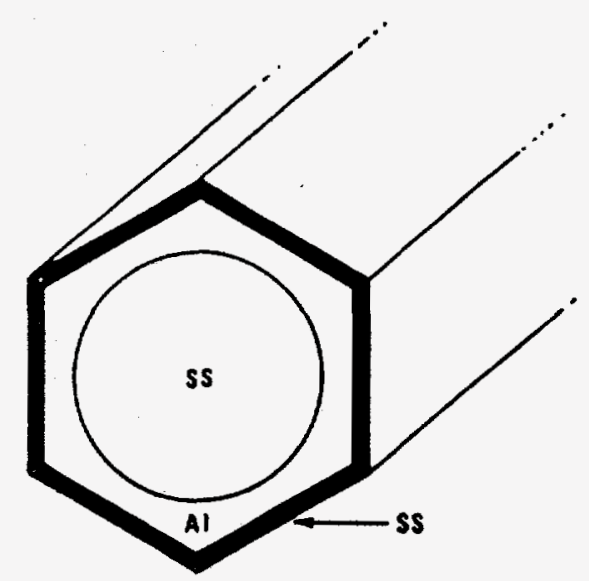

Diam of SS cylinder: $12.98 \mathrm{~cm}$

Width of hexagon (flat wall to flat wall): $15.974 \mathrm{~cm}$

Thickness of SS wrapper: $.462 \mathrm{~cm}$

Diam of Al void: $13.0 \mathrm{~cm}$

Width of aluminum (flat surface to flat surface): $15.05 \mathrm{~cm}$

Length of assembly: $45 \mathrm{~cm}$

Figure 9. SS central blockage hexagon assembly.

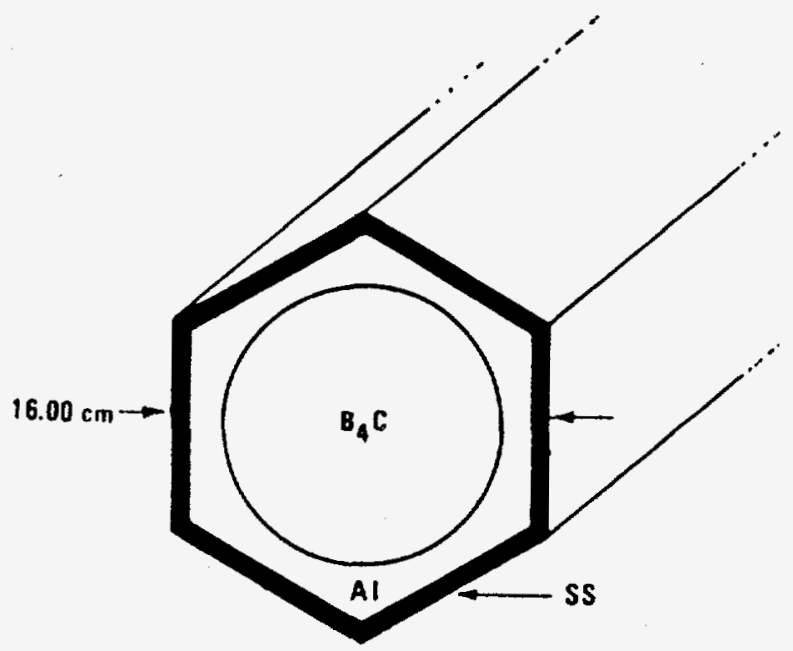

Width of container (flat surface to flat surface): $16.00 \mathrm{~cm}$

Width of Al (flat surface to flat surface): $15.05 \mathrm{~cm}$

Thickness of end plates: $.476 \mathrm{~cm}$

Diam of $\mathrm{B}_{4} \mathrm{C}: 13 \mathrm{~cm}$

Length of $\mathrm{B}_{4} \mathrm{C}: 44.05 \mathrm{~cm}$

Volume of $\mathrm{B}_{4} \mathrm{C}: 5846.9 \mathrm{cc}$

Density of $\mathrm{B}_{4} \mathrm{C}: 1.38 \mathrm{~g} / \mathrm{CC}$

Figure 10. $\mathrm{B}_{4} \mathrm{C}$ central blockage hexagon assembly. 


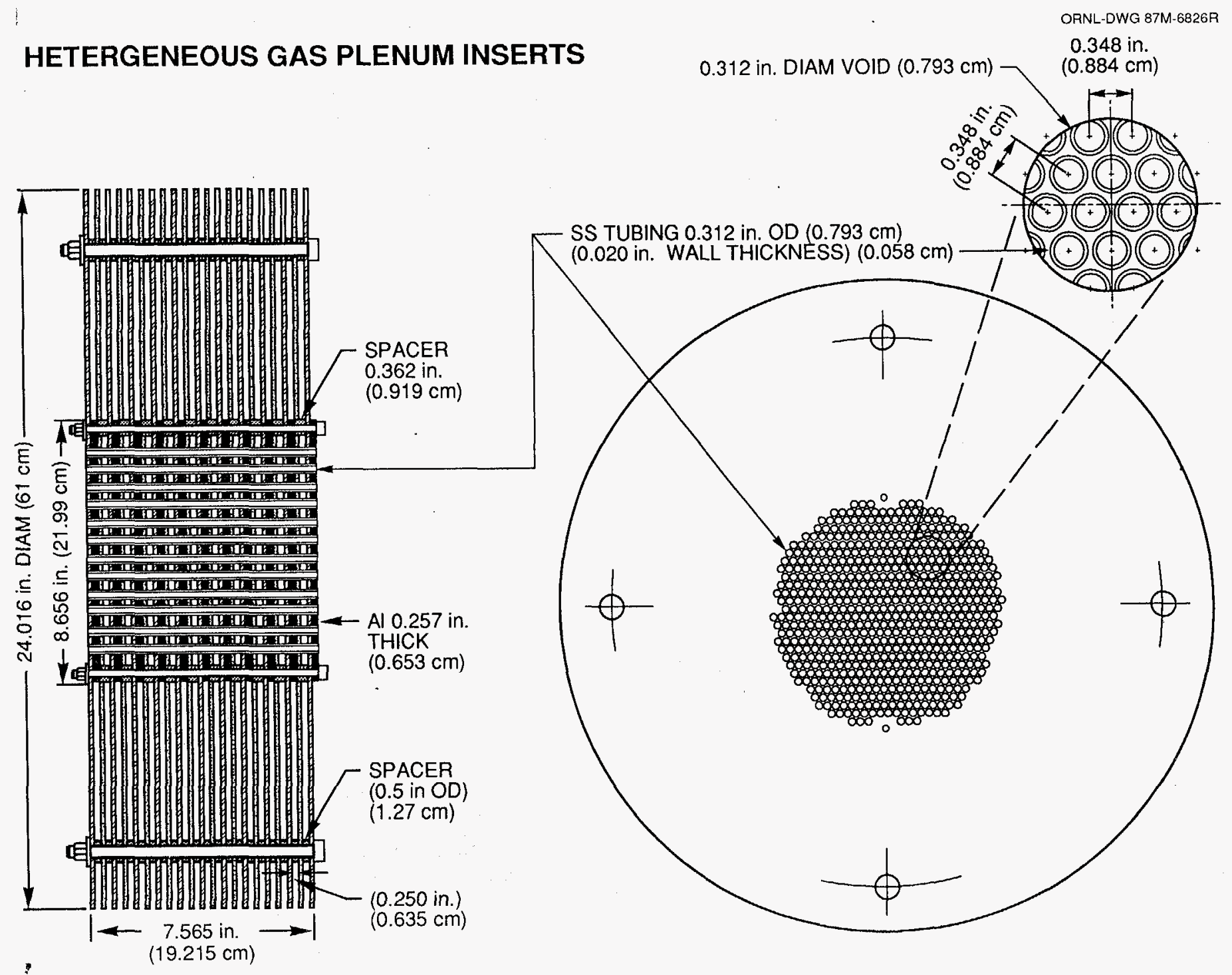

Figure 11. Schematic of heterogeneous fission gas plenum. 


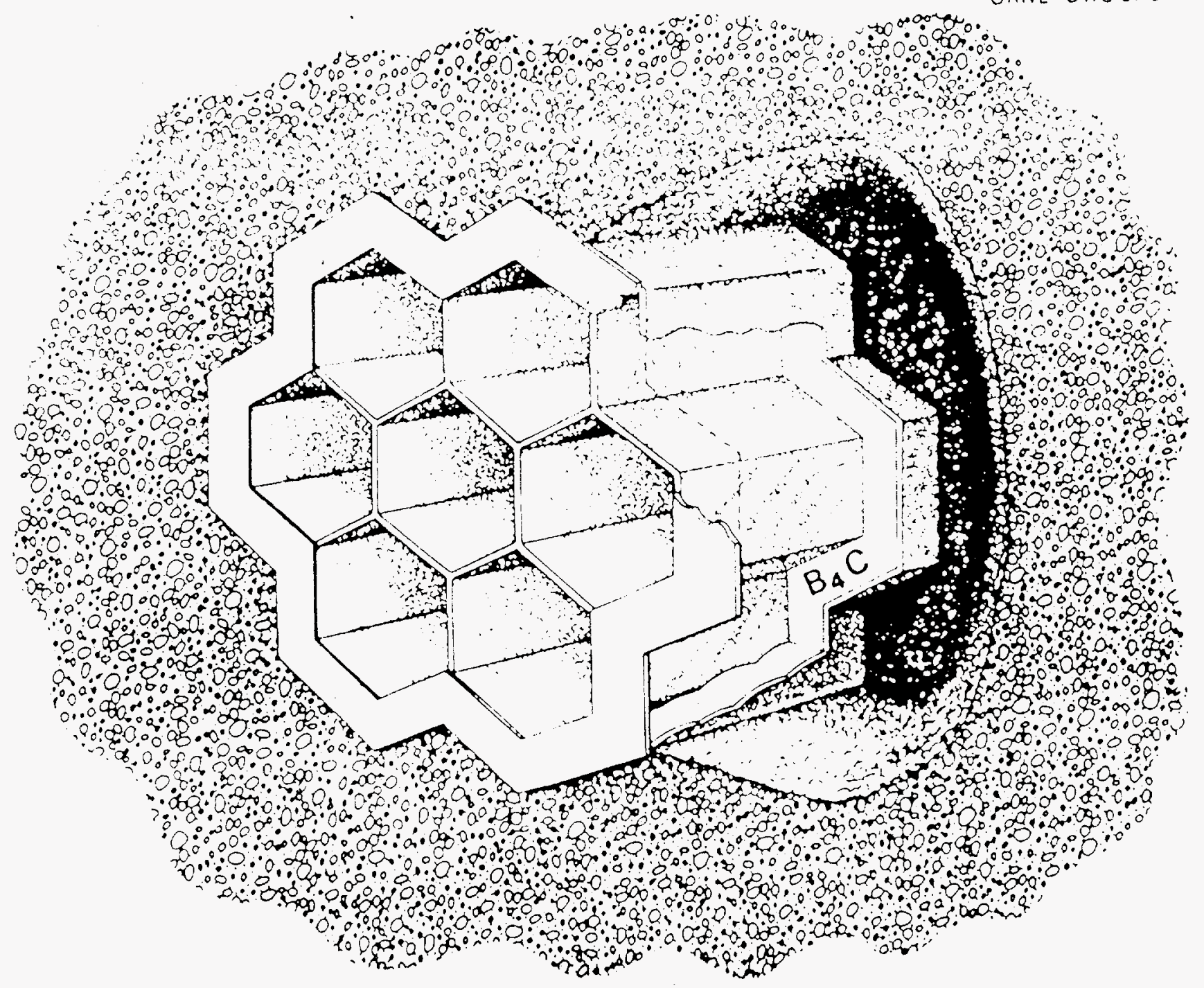

Figure 12. Schematic of the aluminum honeycomb within a concrete slab. 


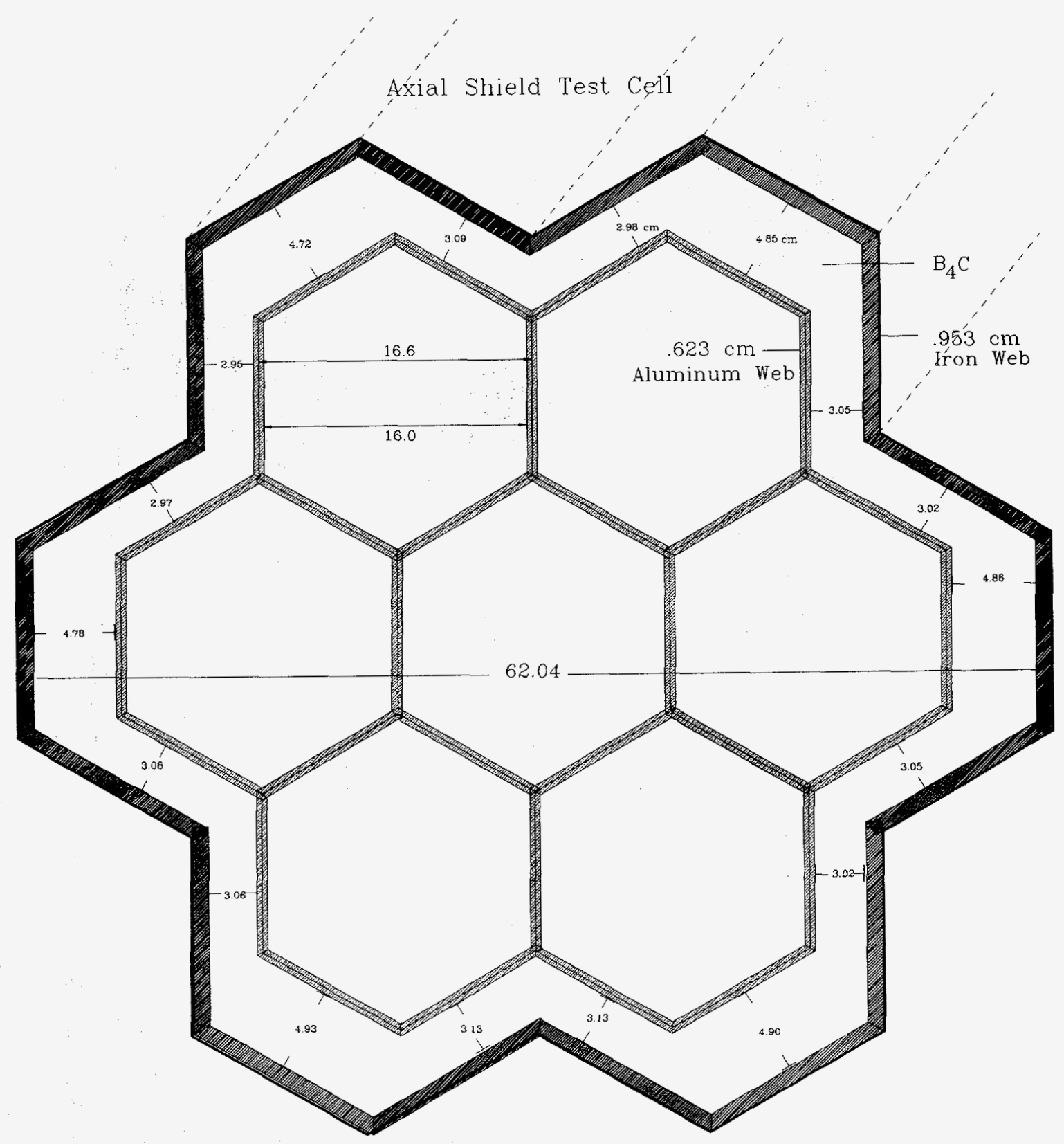

Dimensions in $\mathrm{cm}$

Figure 13. Schematic of aluminum mesh dimensions along with those for the surrounding $\mathrm{B}_{4} \mathrm{C}$ collar. 


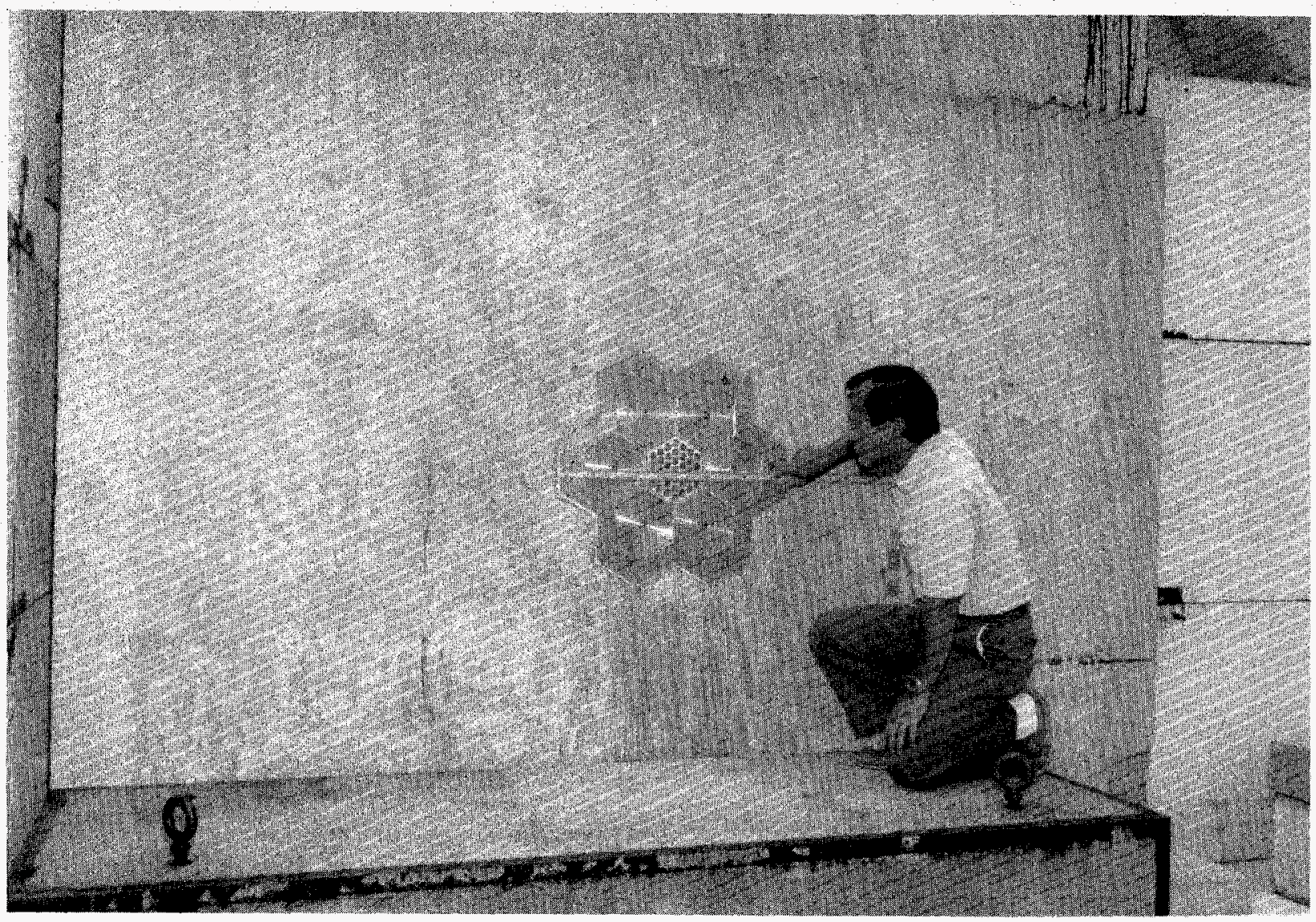

Figure 14. A photograph of a typical axial shield mockup. 

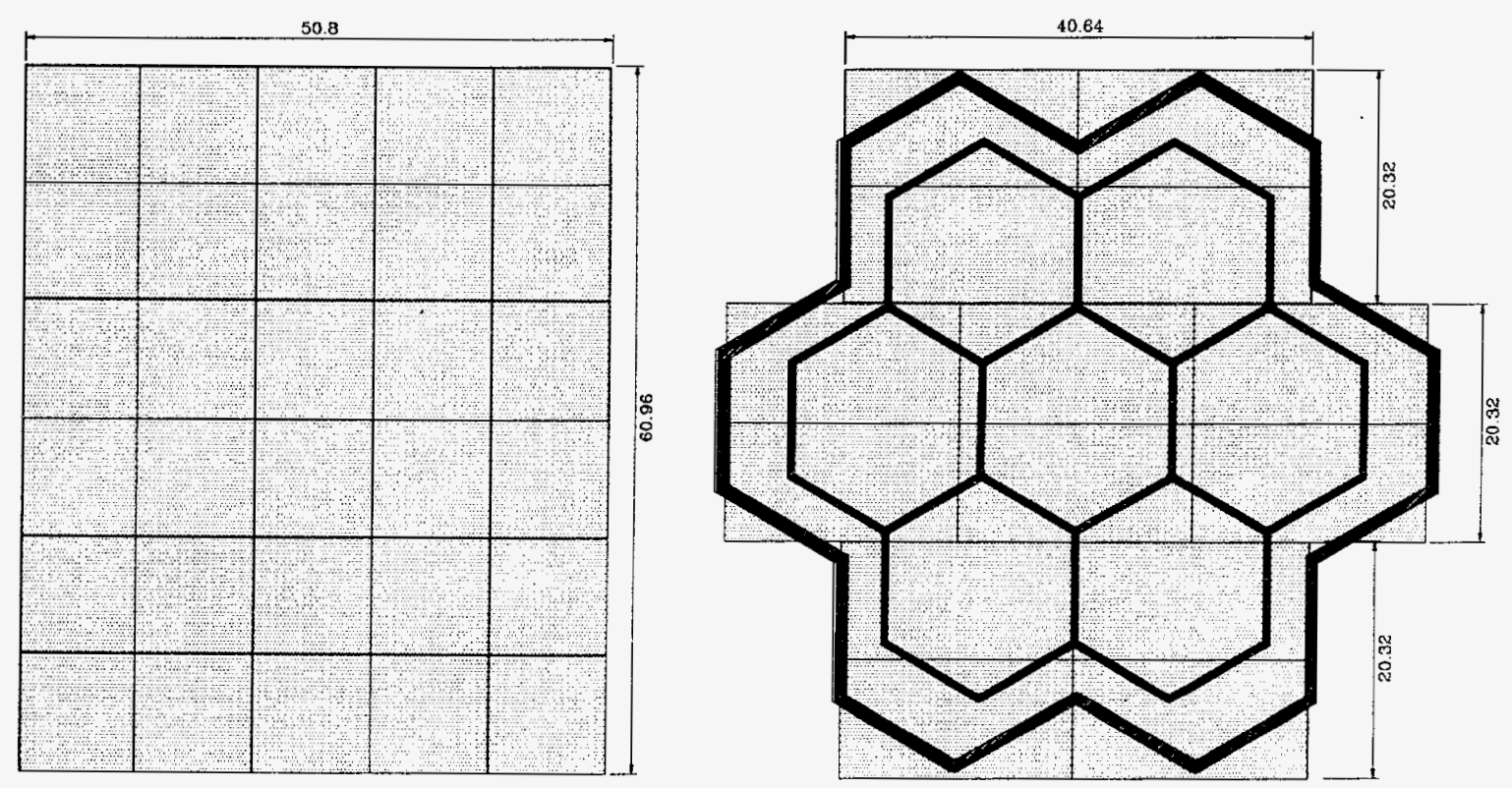

Figure 15. Lithiated paraffin background shield (shaded area) for the Axial Shield experiment. 


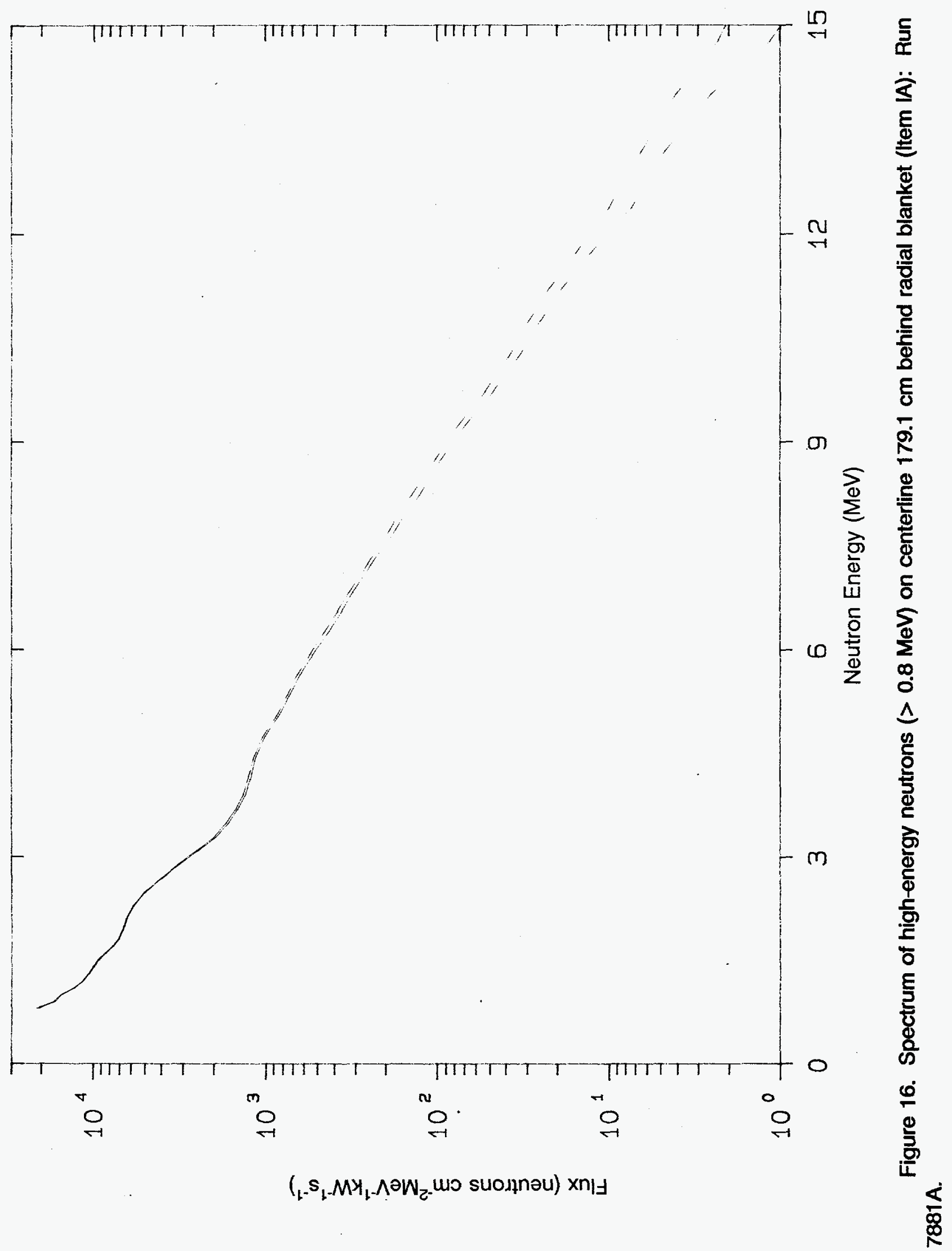




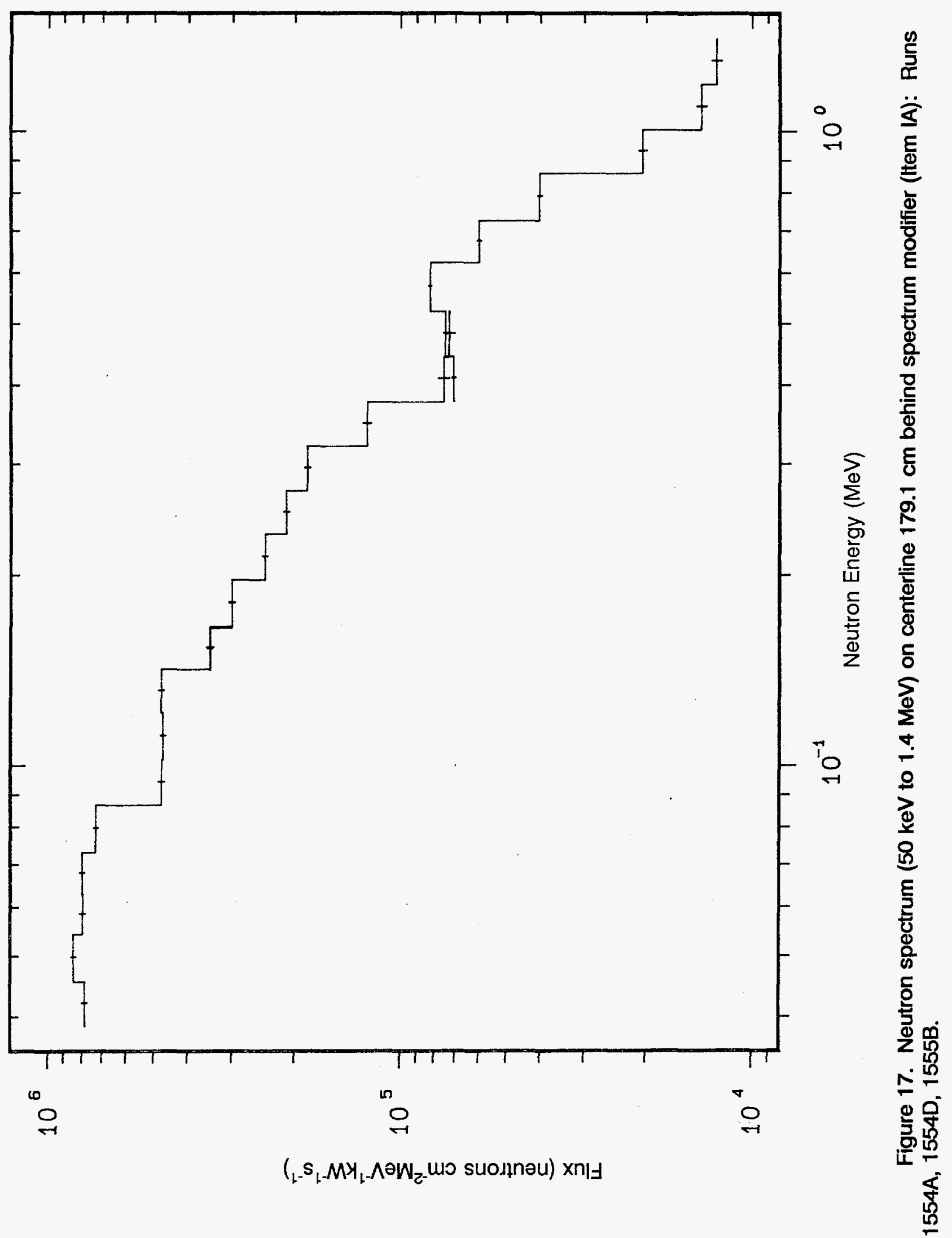




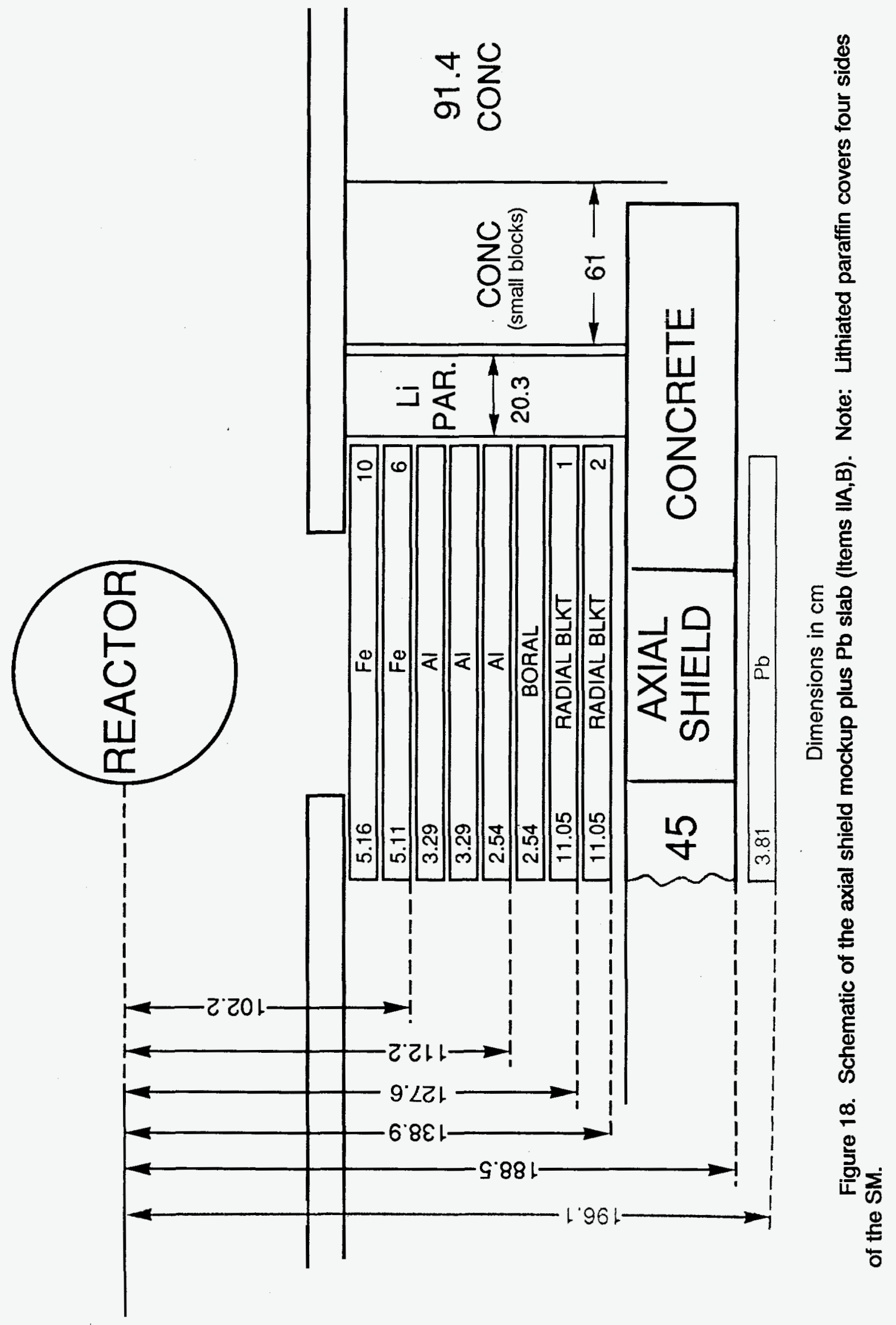




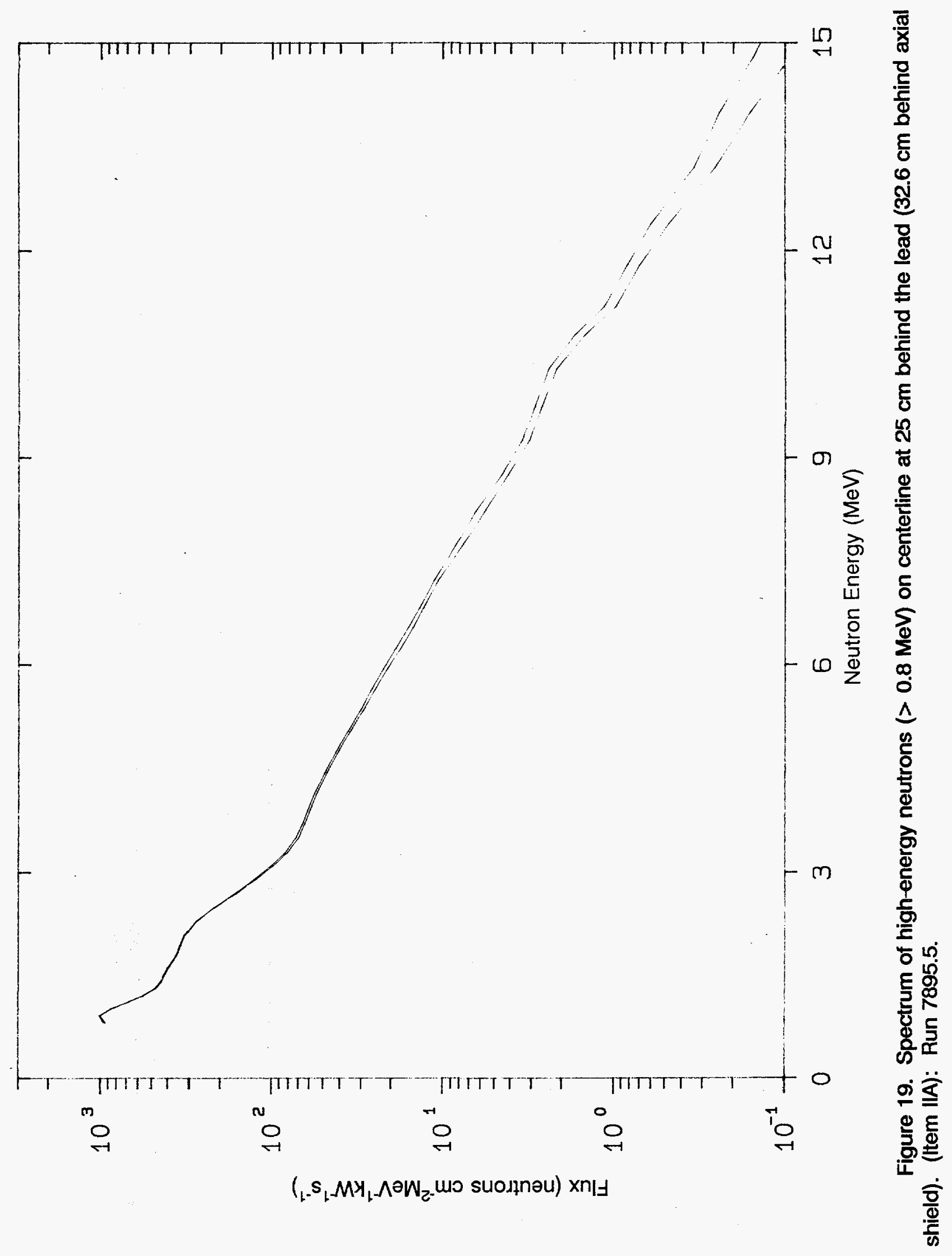




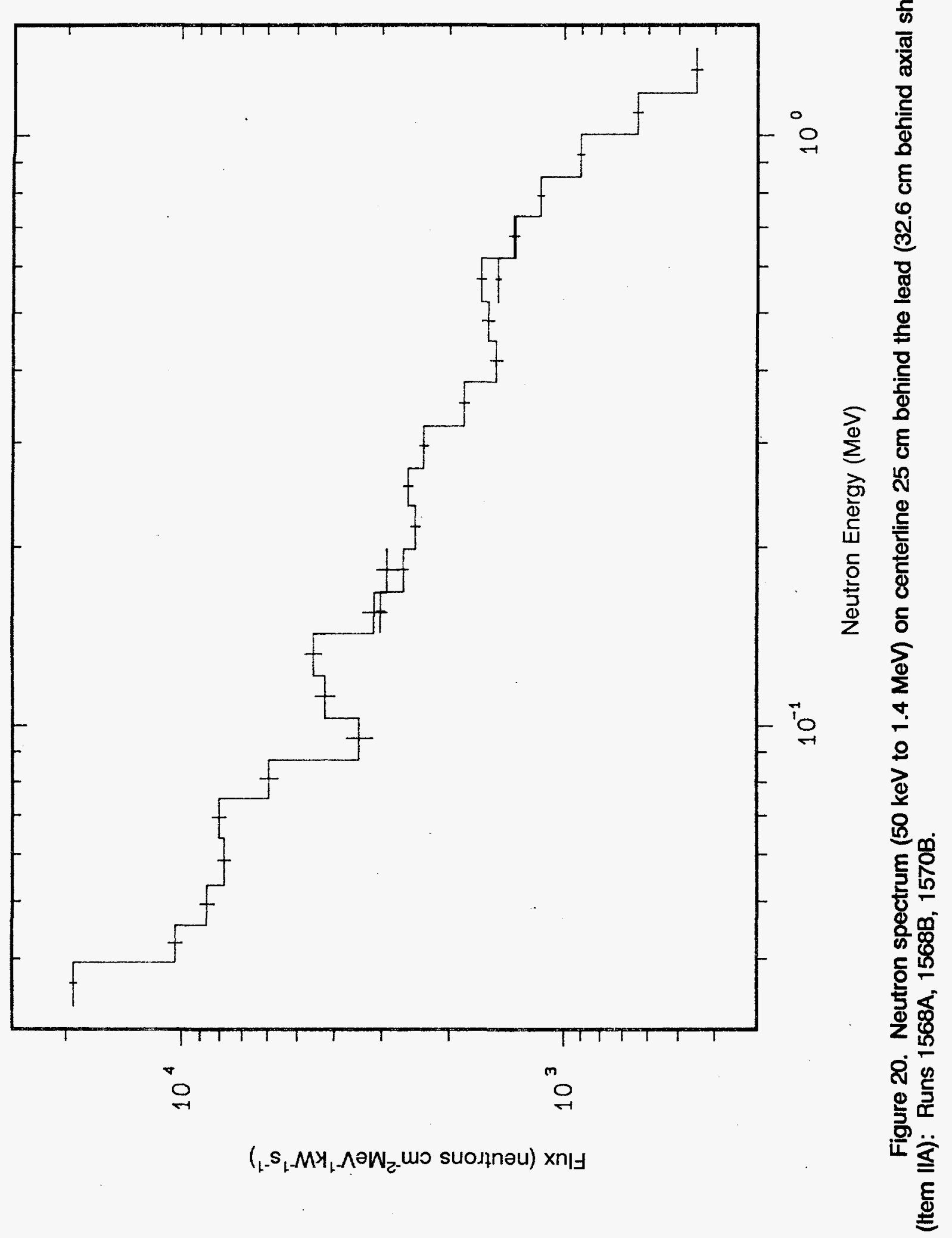




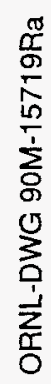

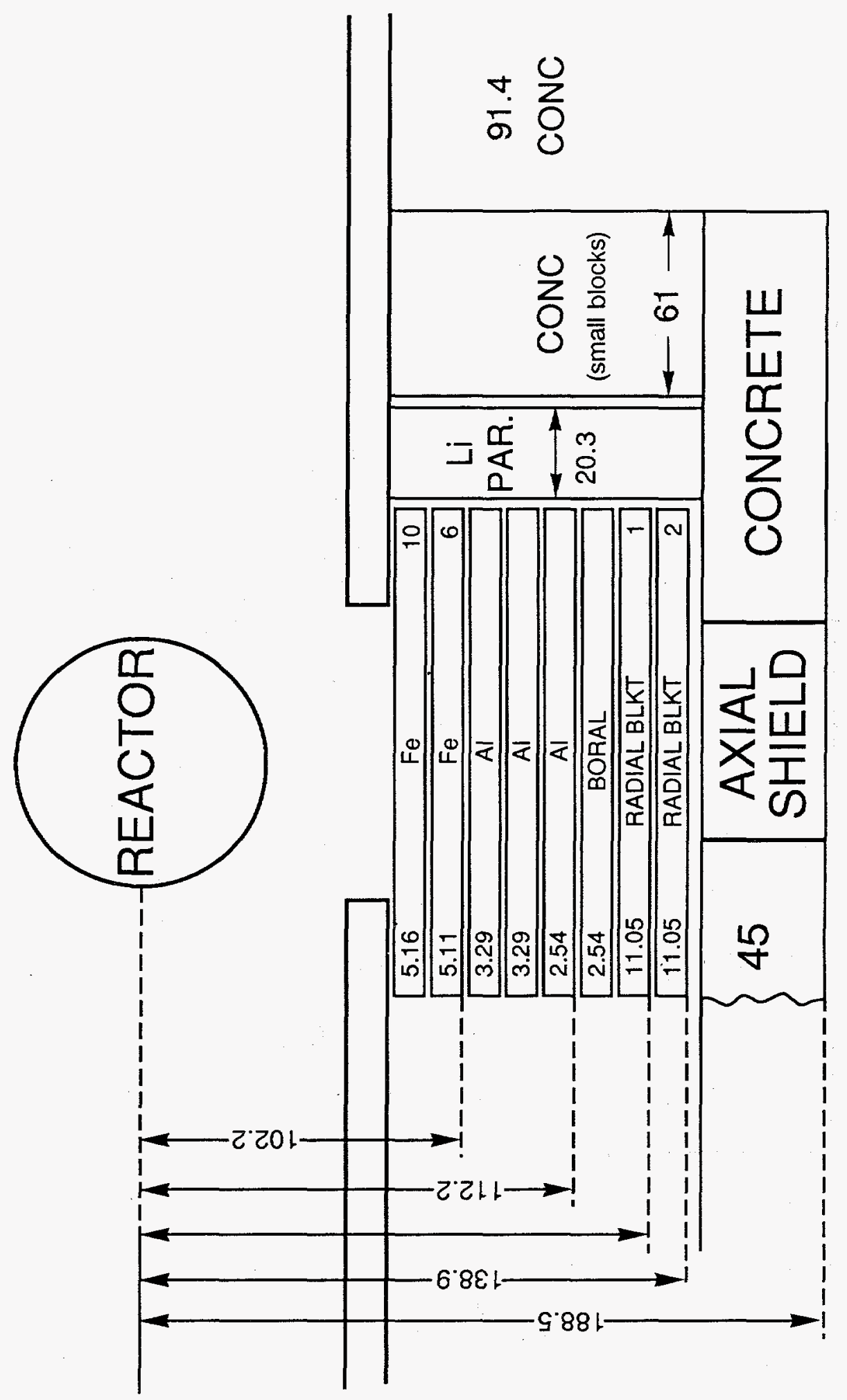

$\frac{8}{0}$

은

峁

들

$\dot{5}$

$\geq$

$\frac{E}{0}$
.$\subseteq$
0
$\frac{9}{0}$
$\frac{O}{0}$
$\frac{2}{0}$
$\frac{E}{0}$

$=$

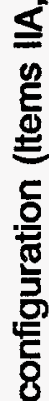

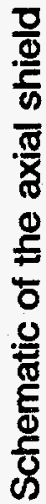

高 


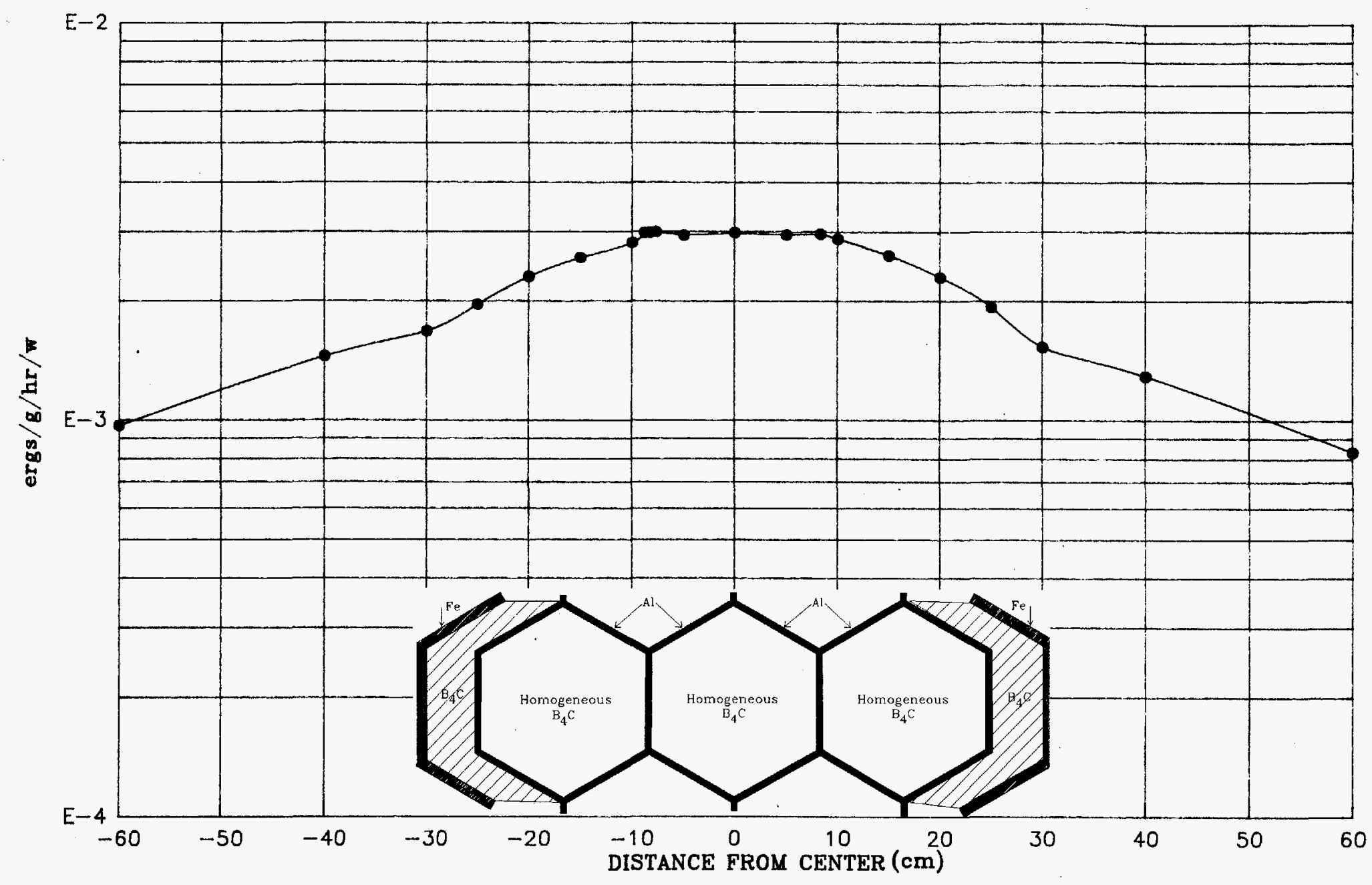
IIA).

Figure 22. Radial traverse $2.37 \mathrm{~cm}$ behind the $\mathrm{B}_{4} \mathrm{C}$ homogeneous hexagon mockup using the Hornyak button (Item 


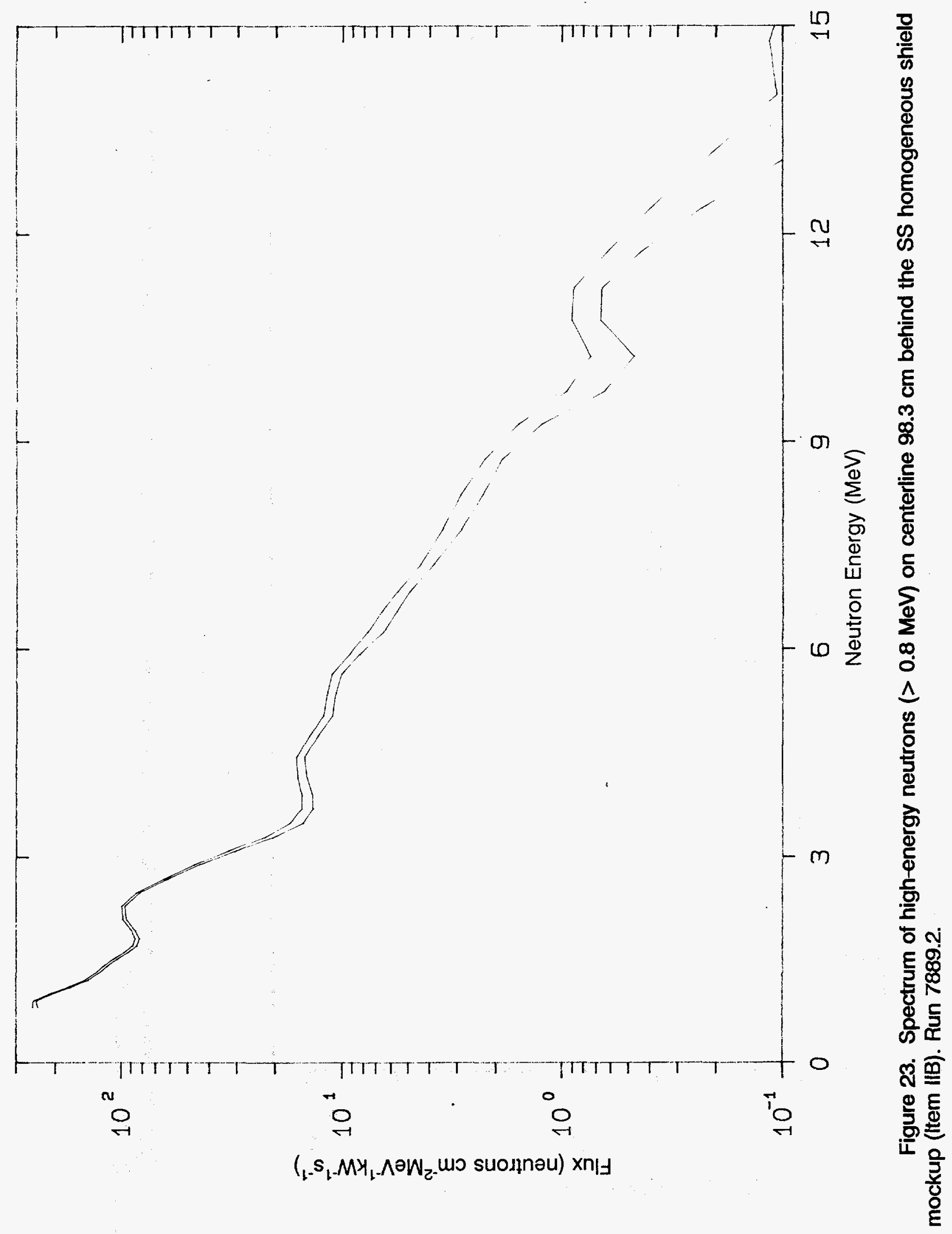




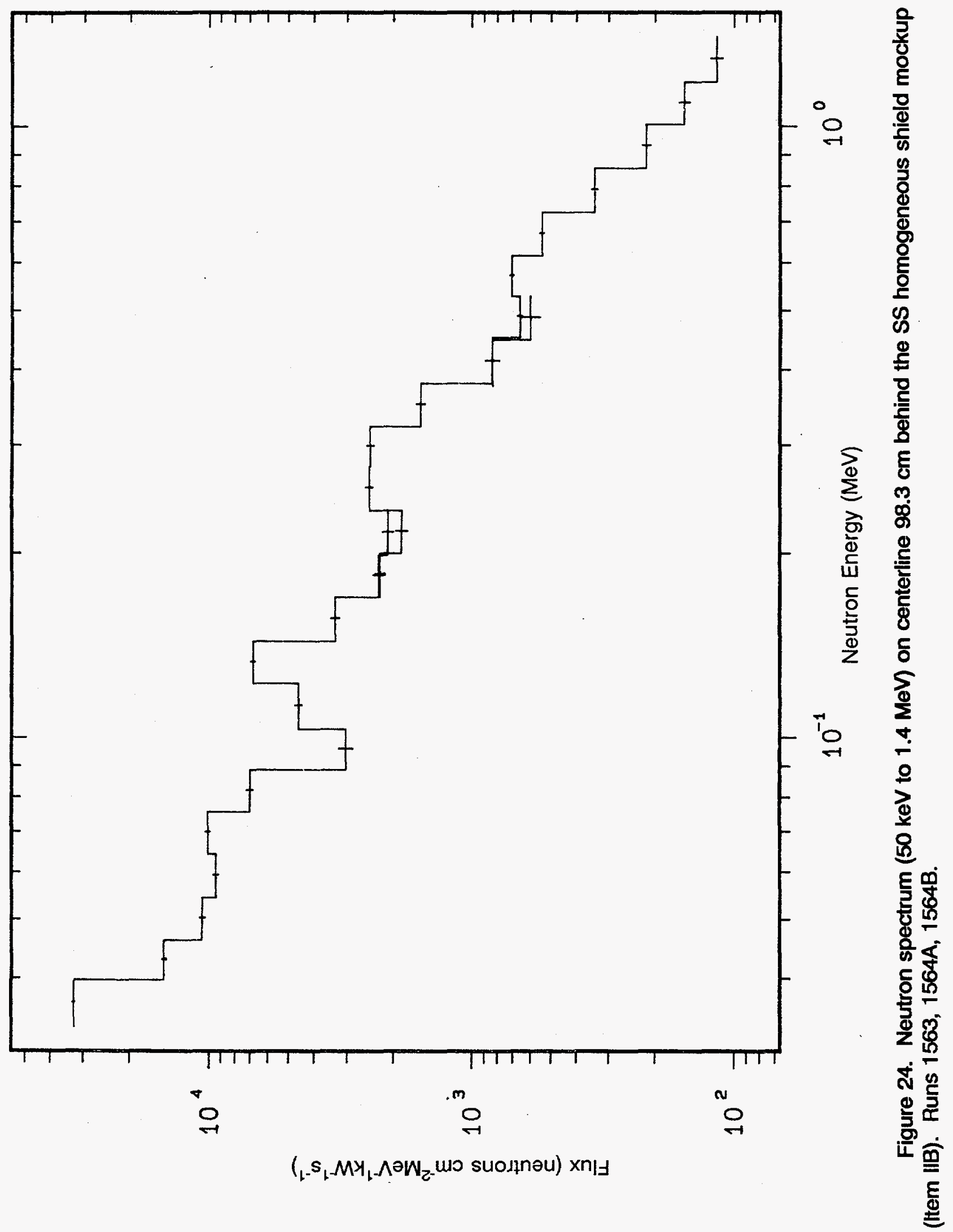




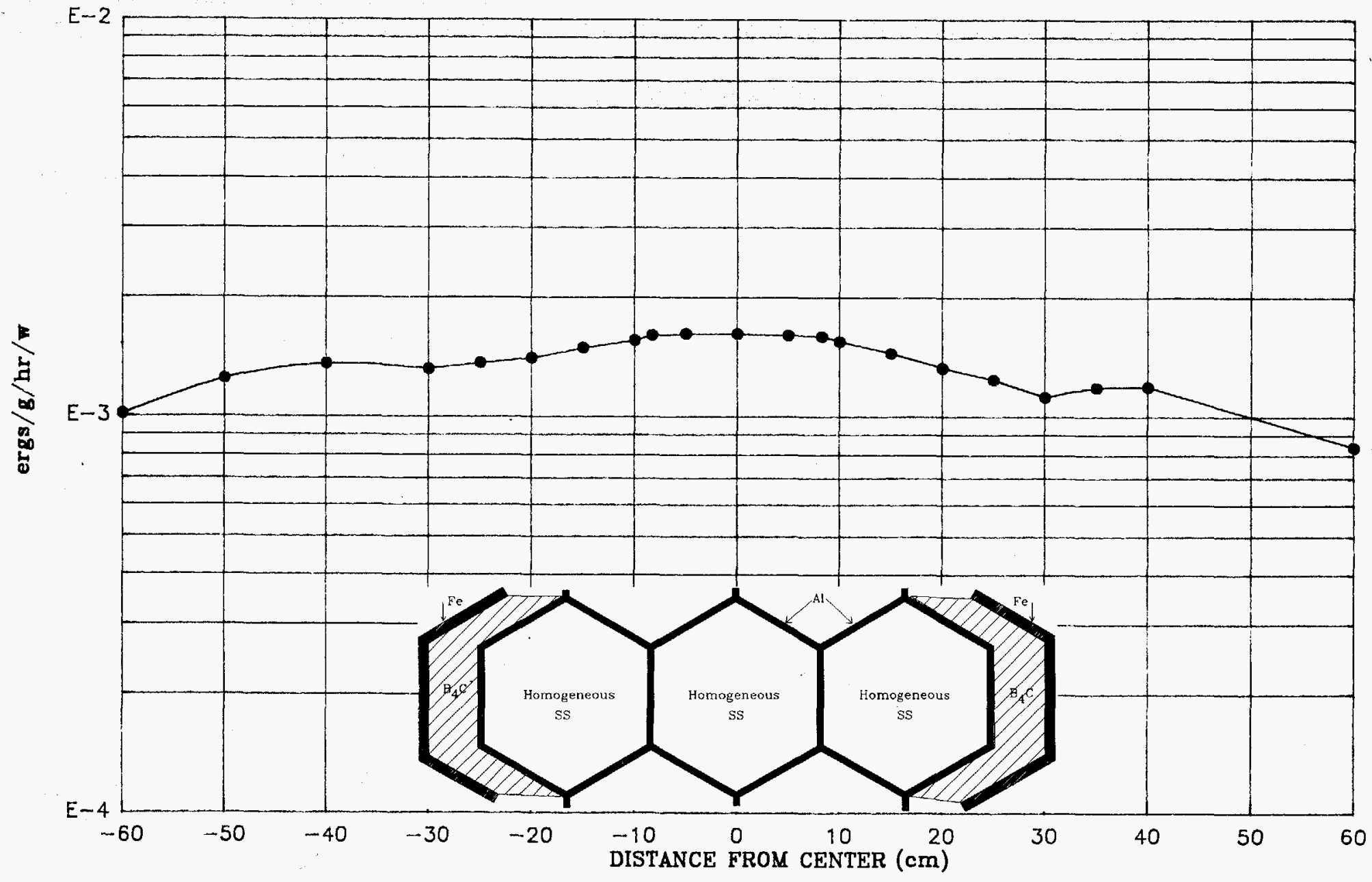

Figure 25. Radial traverse $2.37 \mathrm{~cm}$ behind the SS homogeneous shield mockup using the Hornyak button (Item IIB). 


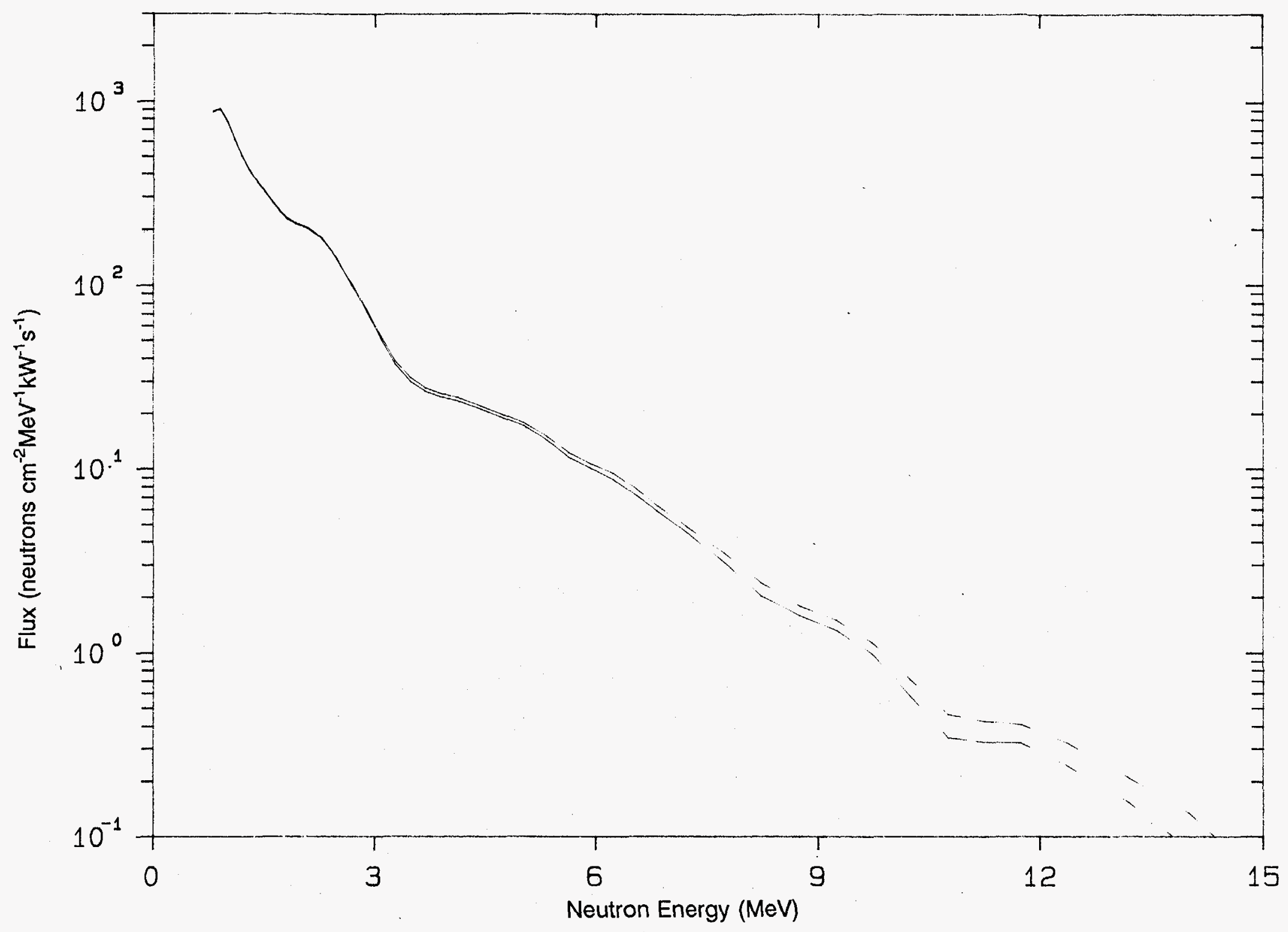

Figure 26. Spectrum of high-energy neutrons ( $>0.8 \mathrm{MeV}$ ) on centerline $25 \mathrm{~cm}$ behind lead $(36.2 \mathrm{~cm}$ behind SS homogeneous shield mockup) (Item IIB). Run 7892.3. 

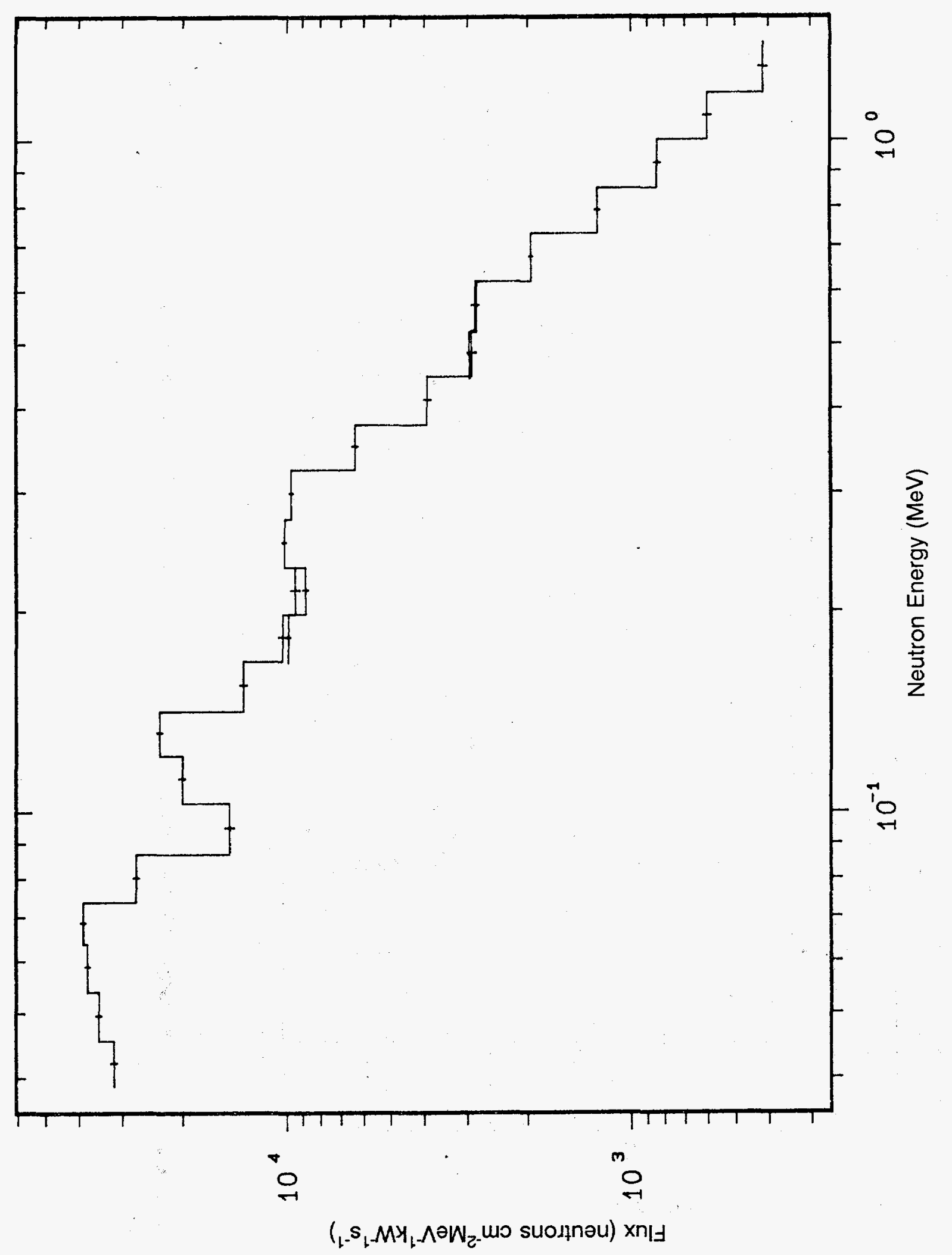

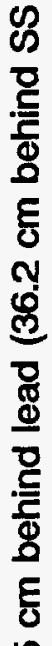

$\sum_{0} \frac{5}{0}$

$\sum$ กิ

ते

岌

든

동

旁

$8 \%$

$5 \frac{\infty}{0}$

5

造

To 봉

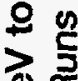

变

ํㅗㅇ

ह 톨

홍응

돈 홍

놀

흐응

ลั 온 


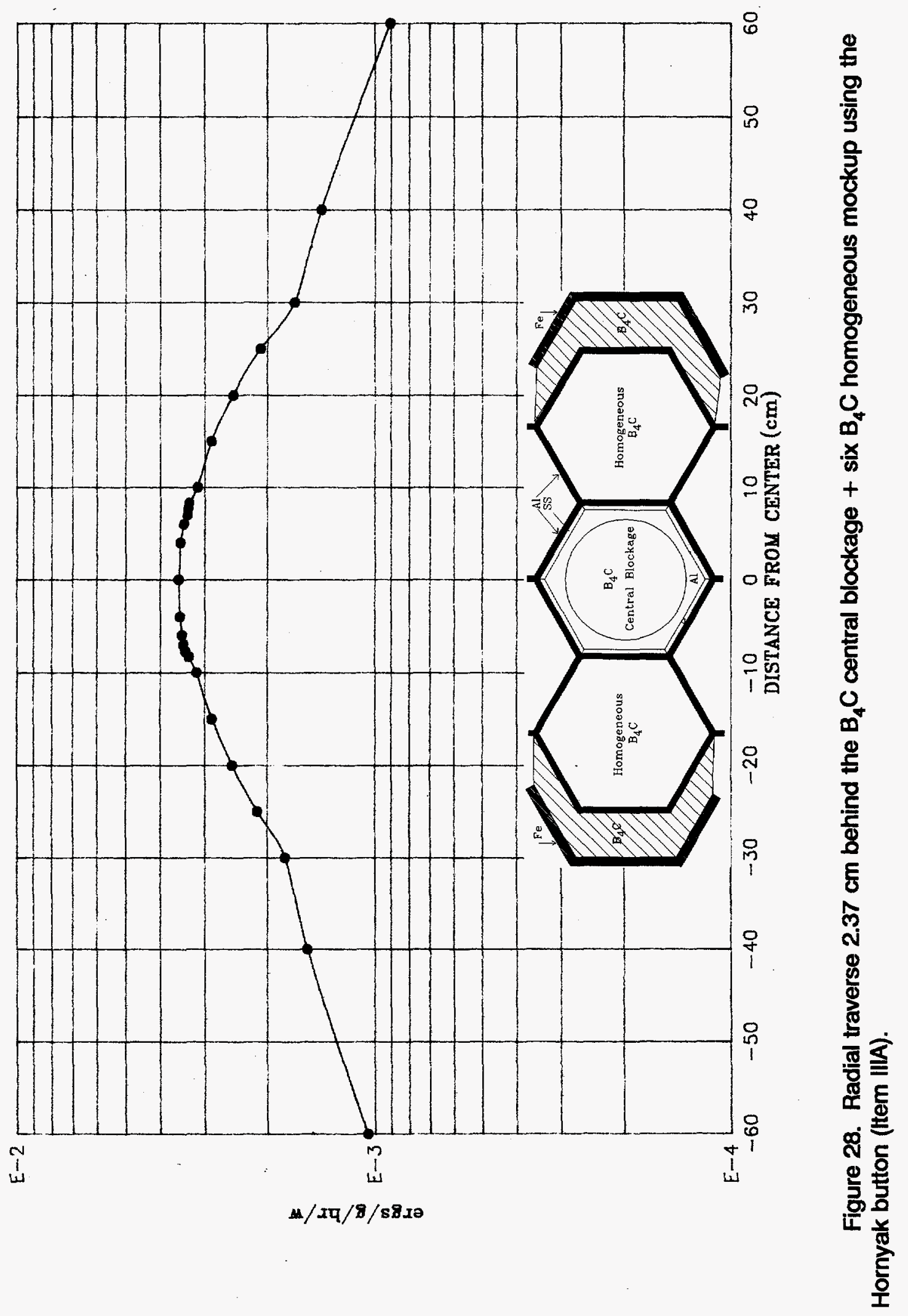




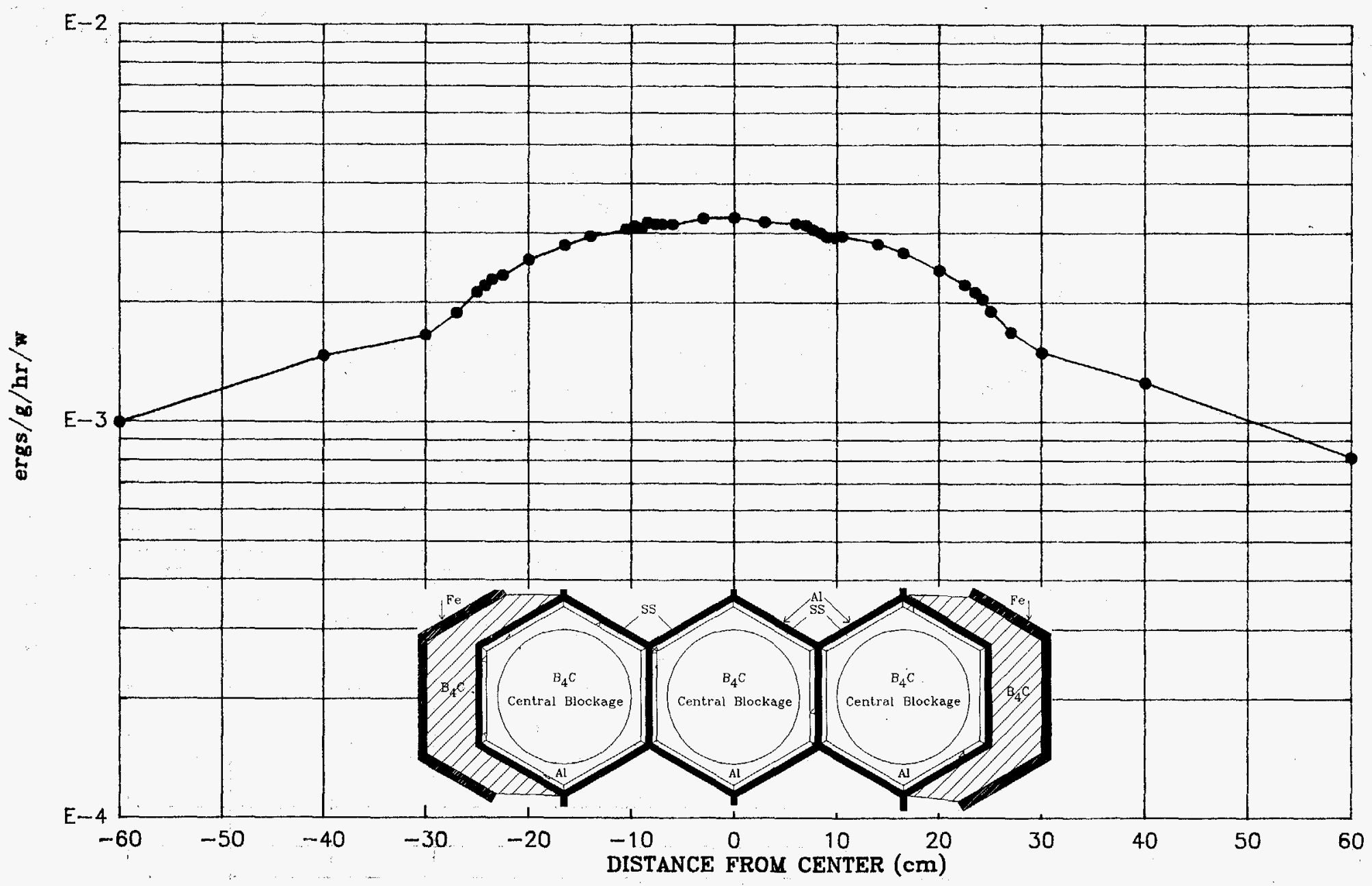

Figure 29. Radial traverse $2.37 \mathrm{~cm}$ behind the $\mathrm{B}_{4} \mathrm{C}$ central blockage type shield mockup using the Hornyak button (Item IIIB). 


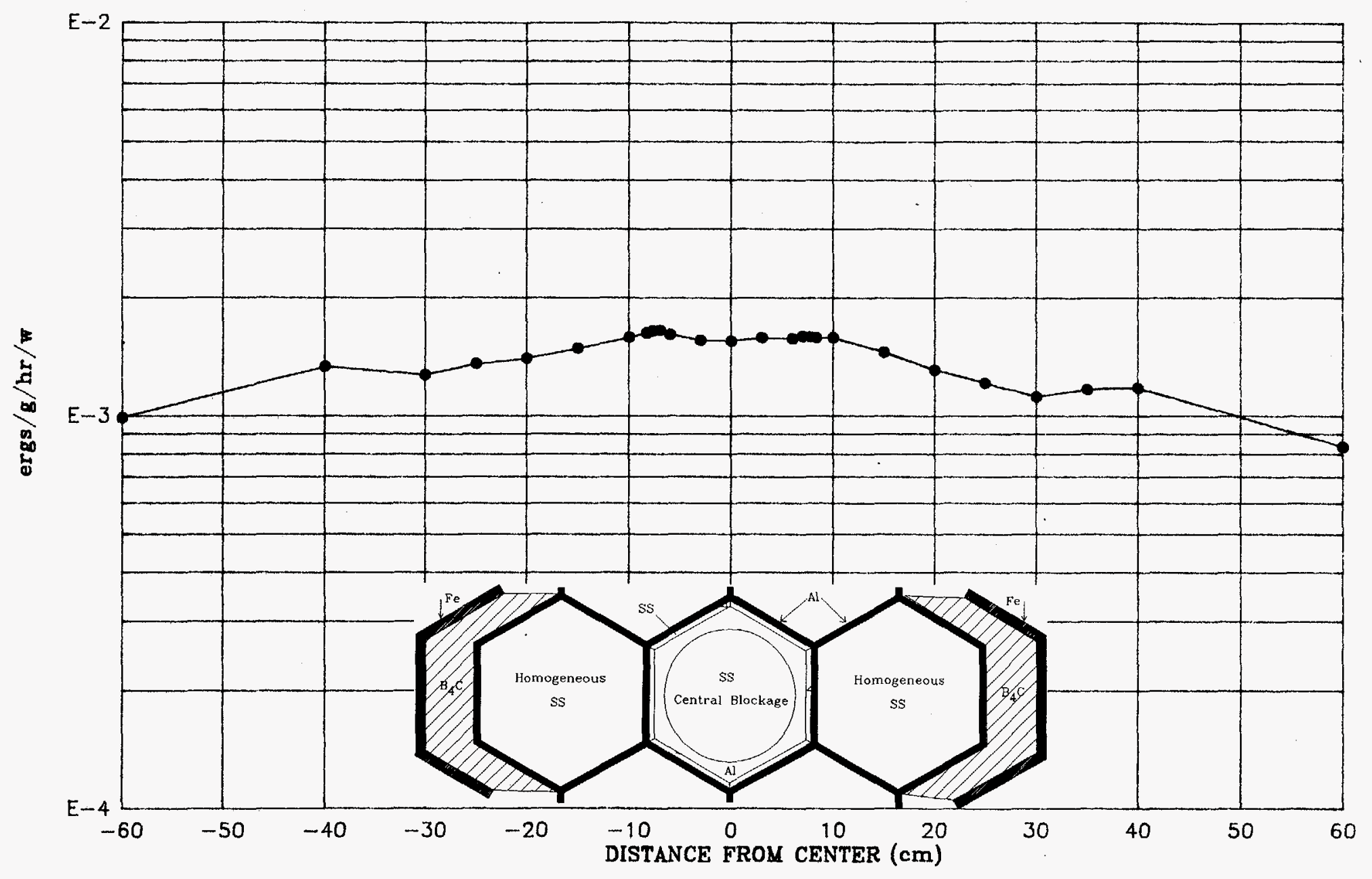

Figure 30. Radial traverse $2.37 \mathrm{~cm}$ behind the SS central blockage + six SS homogeneous-type shield mockup using the Hornyak button (Item IIIC). 


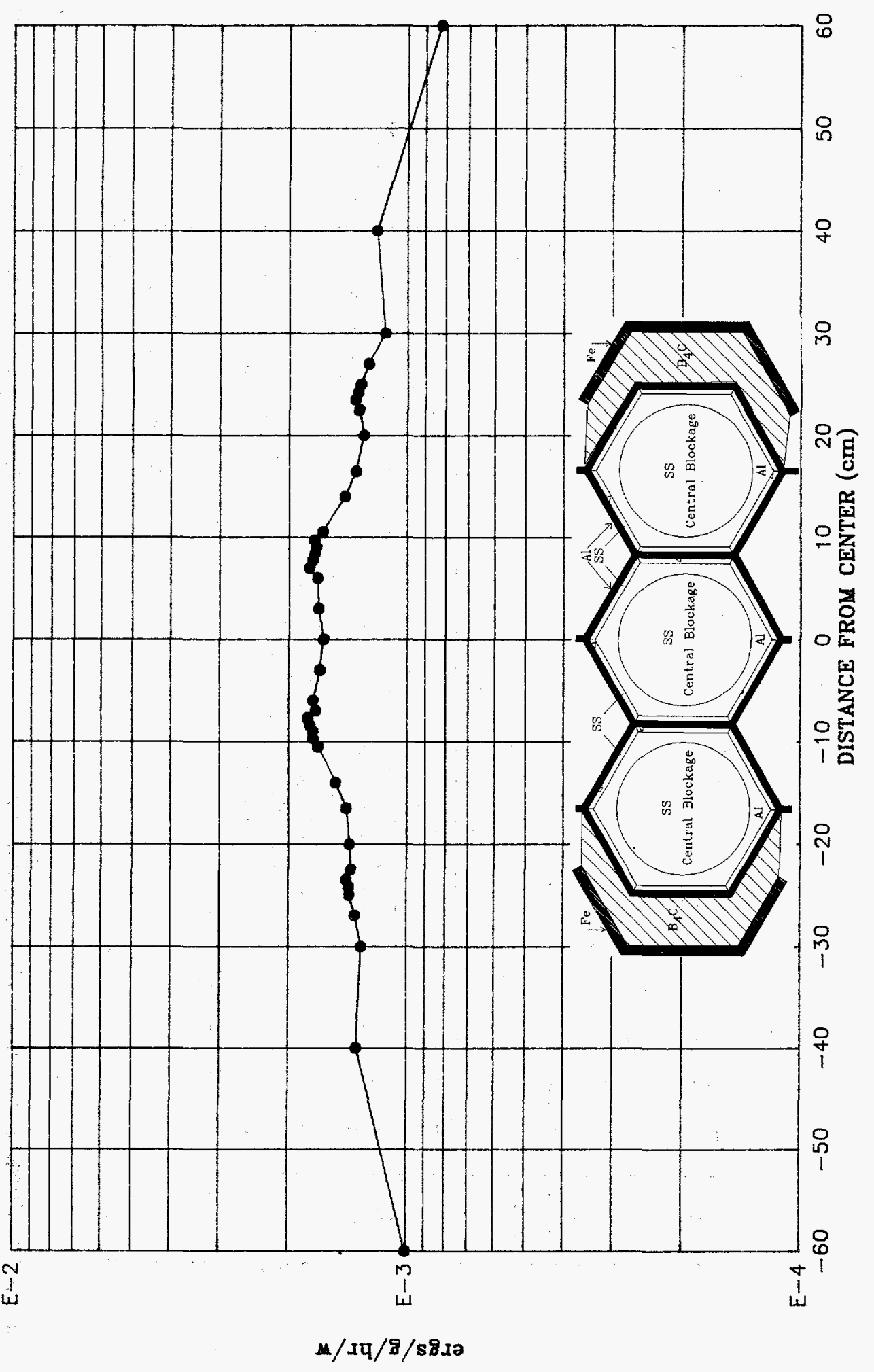

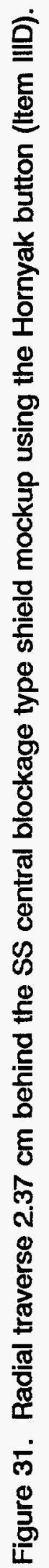


ORNL-DWG 90M-16106

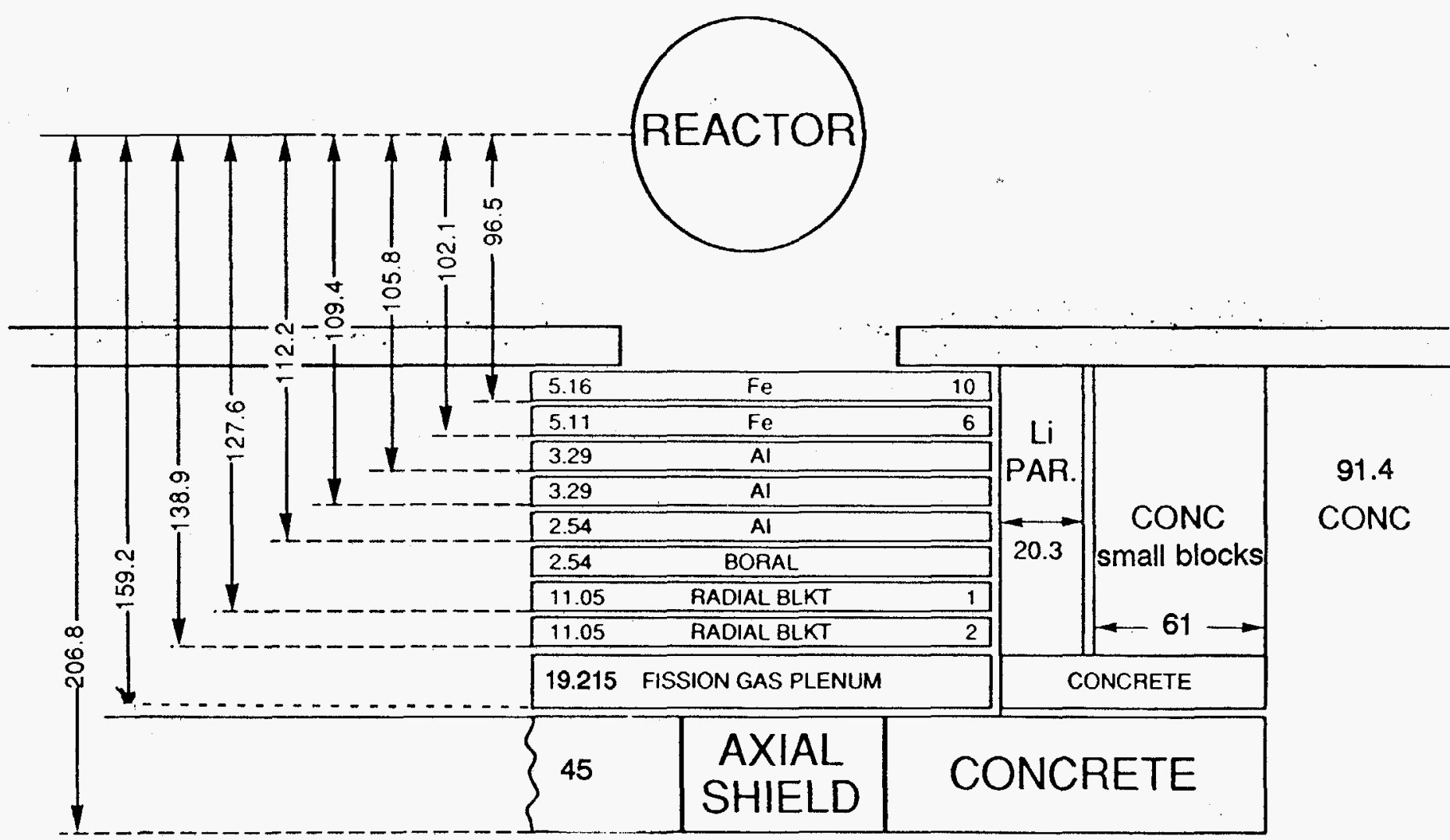

Dimensions in $\mathrm{cm}$

Figure 32. Schematic of the fission gas plenum + seven $\mathrm{B}_{4} \mathrm{C}$ central blockage type shield mockup (Item IIIE). Note: Lithiated paraffin covers four sides of the SM configuration. 


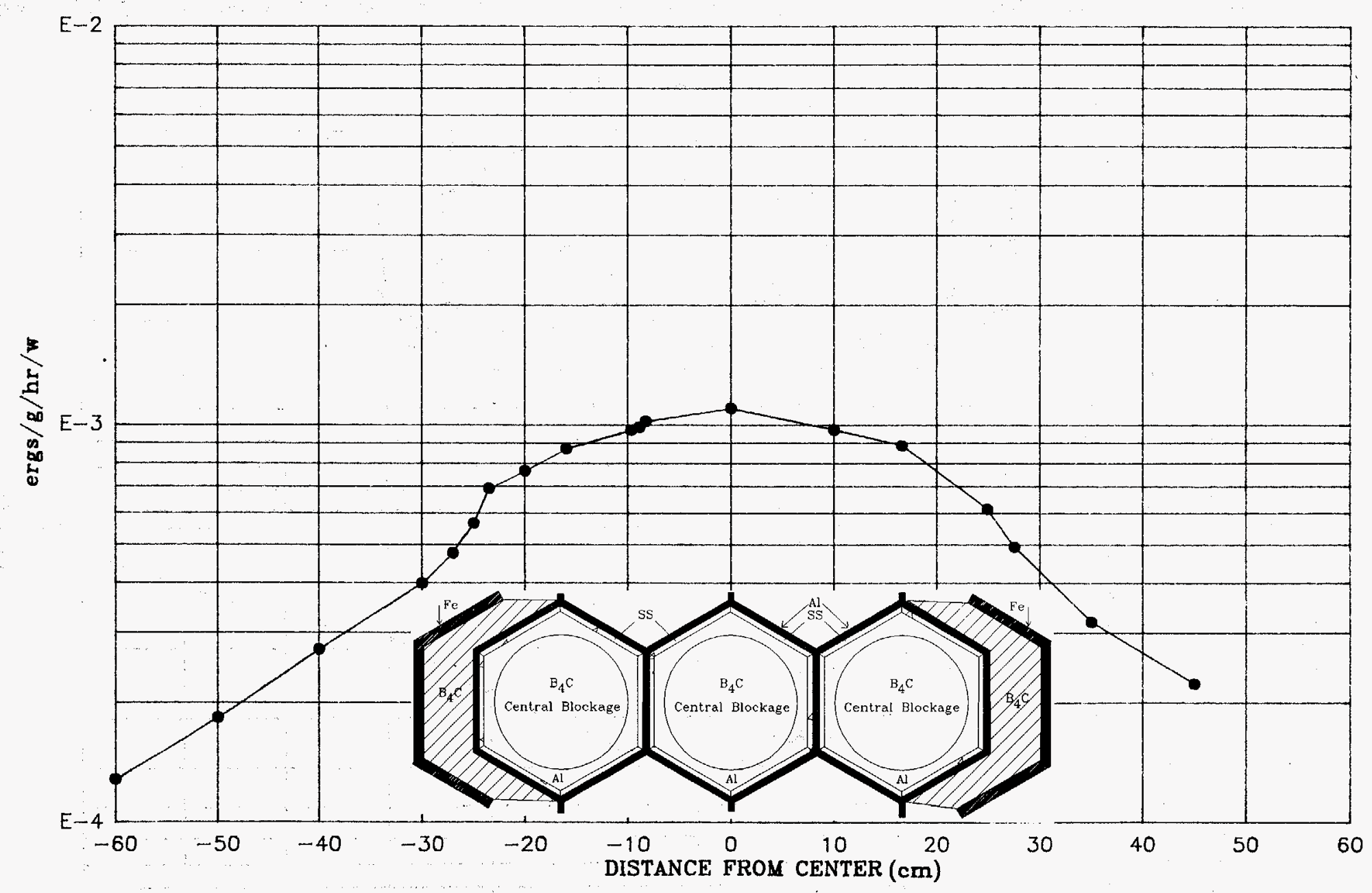

Figure 33. Radial traverse $1.85 \mathrm{~cm}$ behind the fission gas plenum $+\operatorname{seven} \mathrm{B}_{4} \mathrm{C}$ central blockage type shield mockup using the Hornyak button (Item IIIE). 


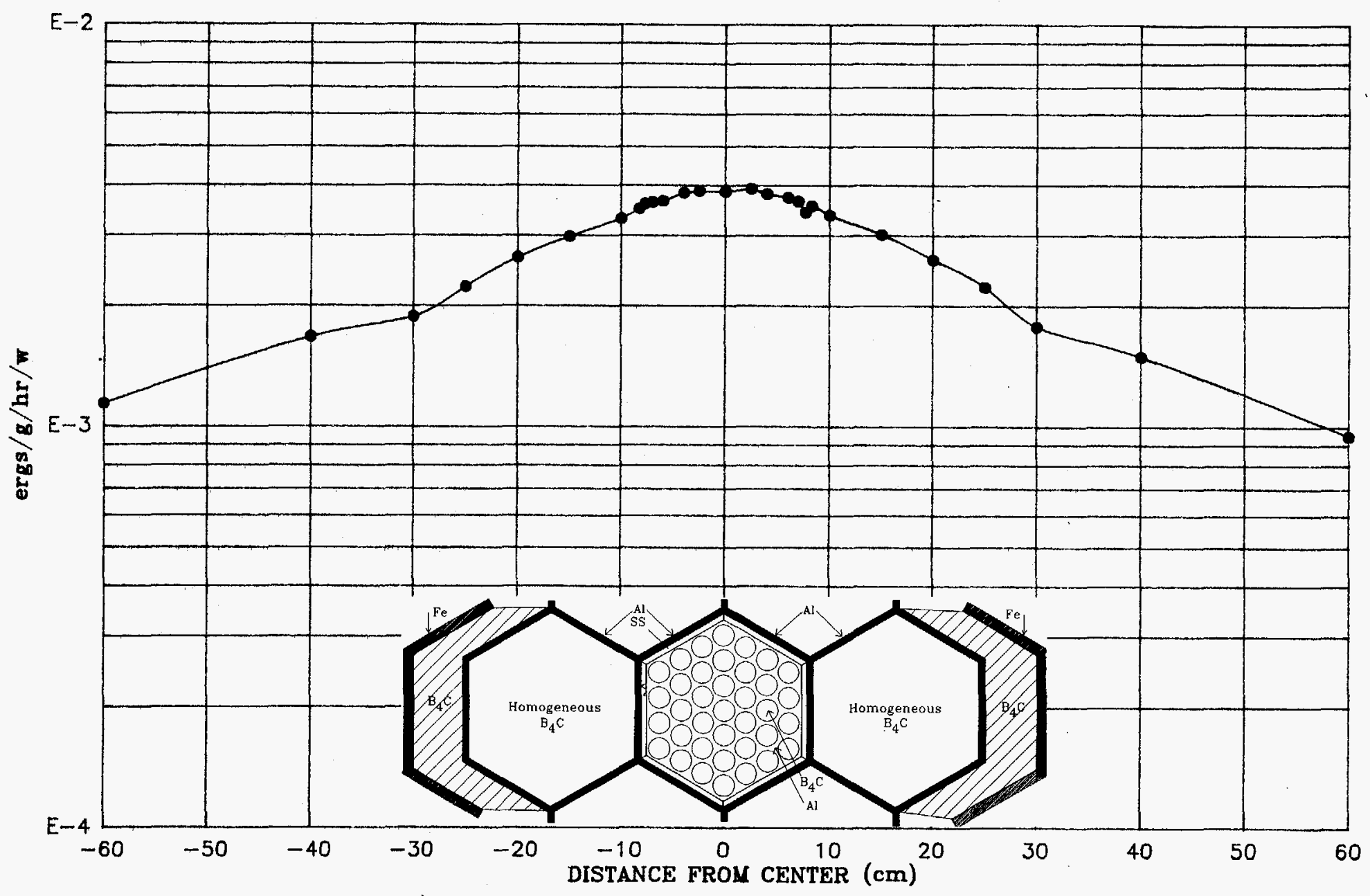

Figure 34. Radial traverse $2.37 \mathrm{~cm}$ behind the $\mathrm{B}_{4} \mathrm{C}$ rod bundle + six $\mathrm{B}_{4} \mathrm{C}$ homogeneous-type shield mockup using the Hornyak button (Item IVA). 


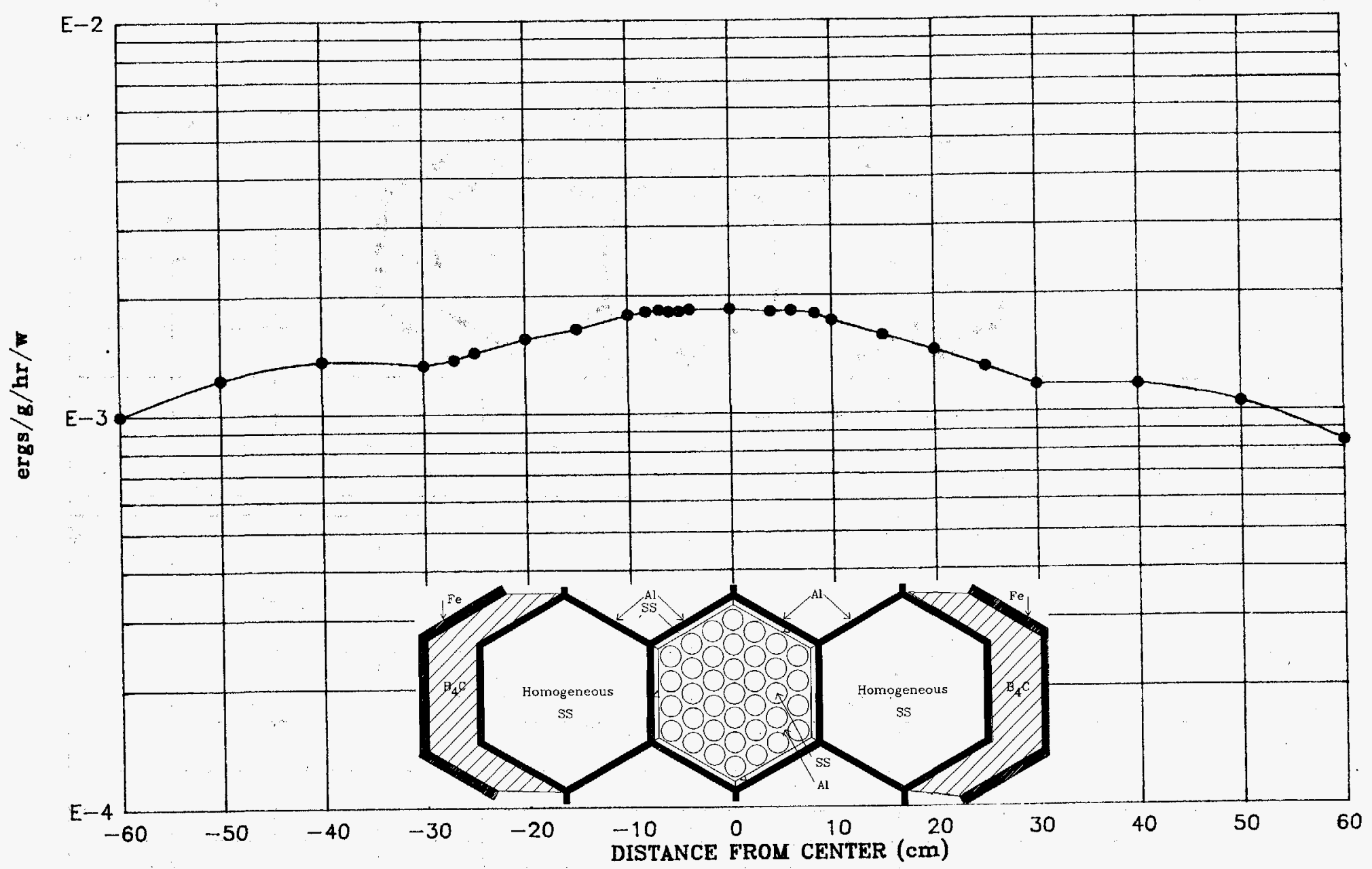

Figure 35. Radial traverse $2.37 \mathrm{~cm}$ behind the SS rod bundle + six SS homogeneous-type shield mockup using the Hornyak button (ttem IVB). 


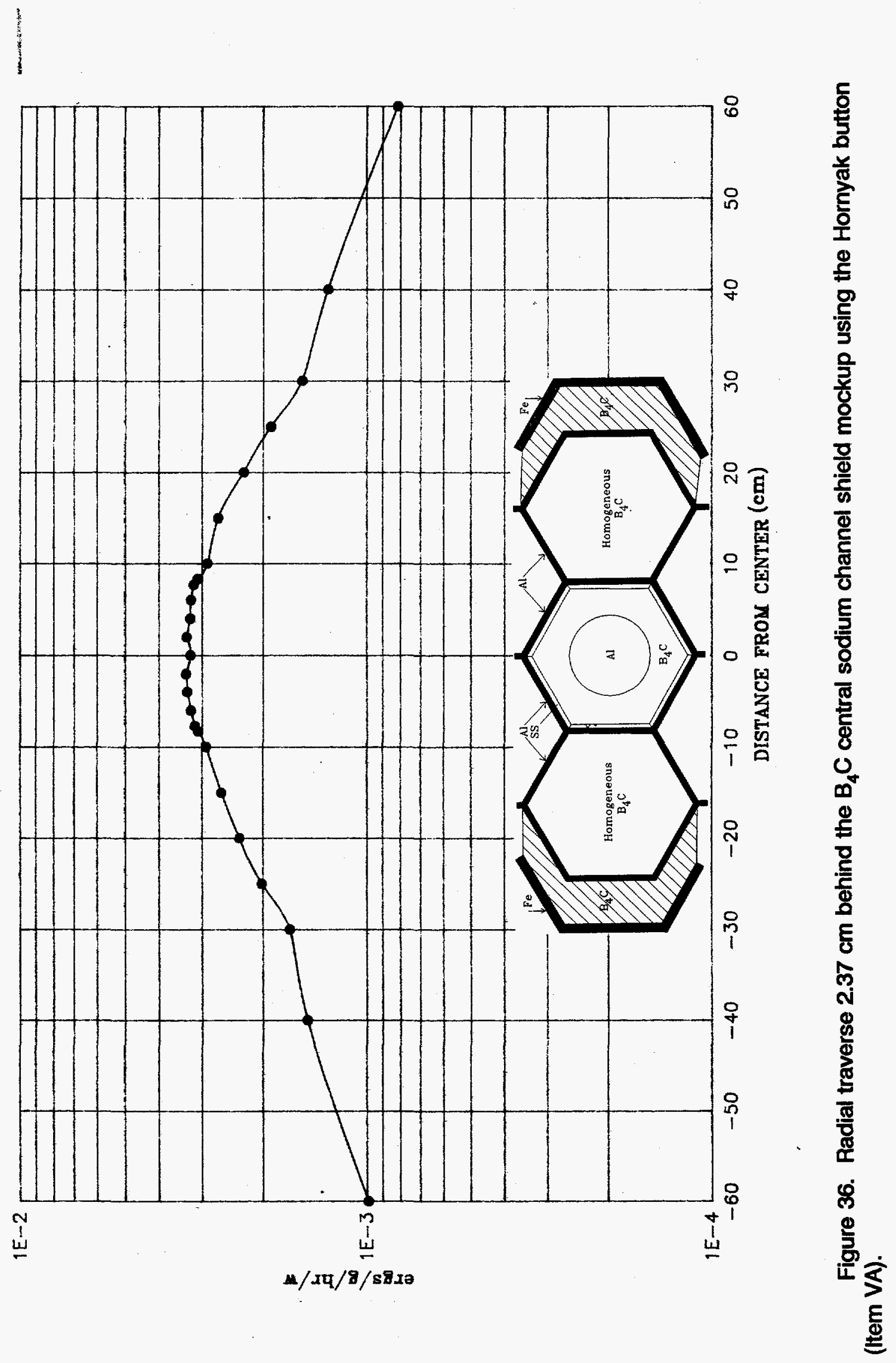




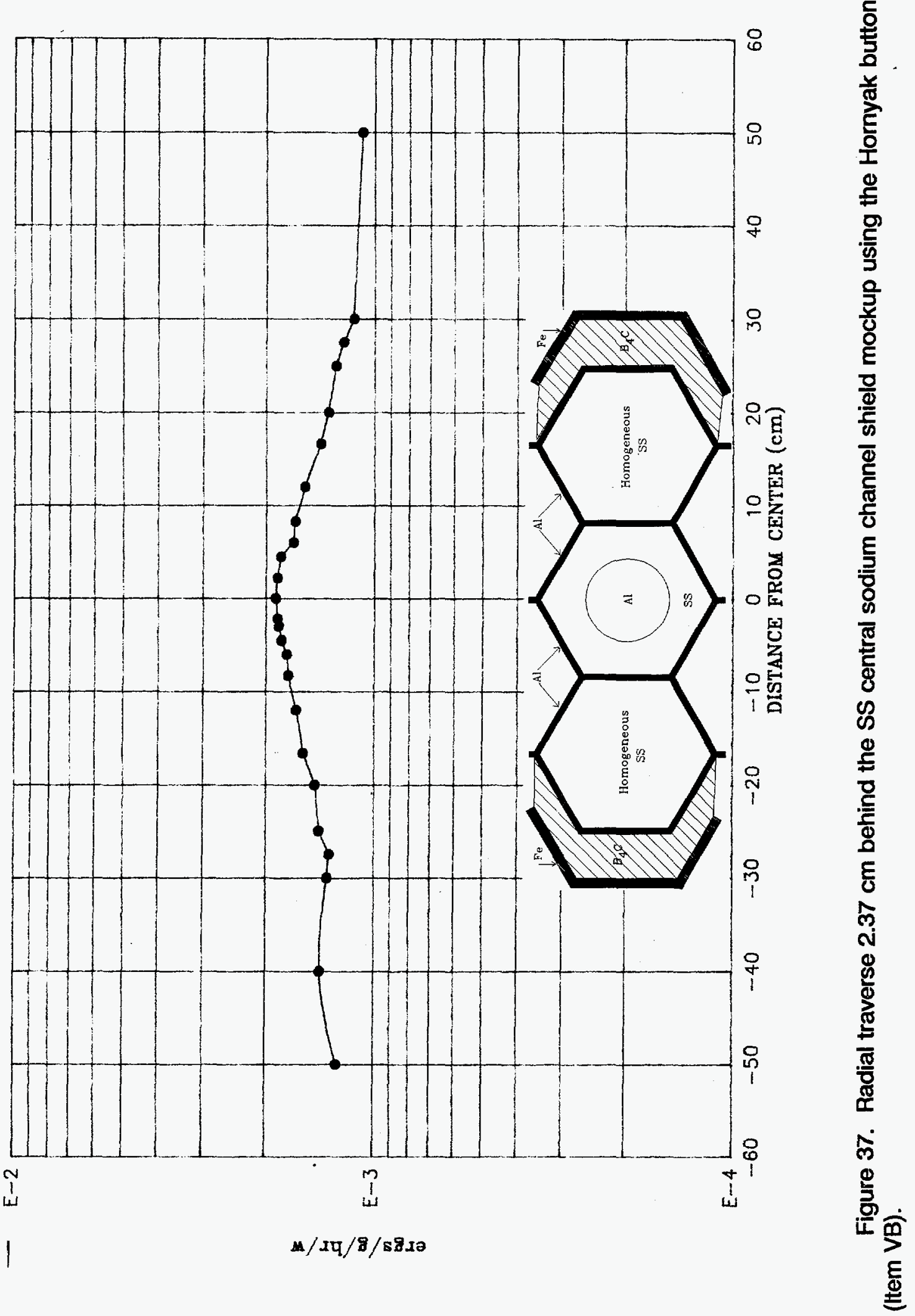


DISTRIBUTION

ORNLTM-11839

Distribution Category

$4 \mathrm{C} 534$

1. B. R. Appleton

2. R. S. Booth

3. J. A. Harvey

4. L. B. Holland

5. F. J. Homan

6-10. H. T. Hunter

11. D. T. Ingersoll

12-13. F. J. Muckenthaler

14. J. V. Pace, III

15. R. W. Peelle

16. A. Shono

17. C. O. Slater
18-22. R. R. Spencer

23. R. C. Ward

24. J. D. White

25. L. R. Williams

26. A. Zucker

27. Central Research Library

28-32. EPMD Reports Office

33. ORNL Y-12 Technical Library Document Reference Section

34-36. Laboratory Records

37. ORNL Patent Office

\section{EXTERNAL DISTRIBUTION}

38. Office of Assistant Manager for Energy Research and Development, DOE-OR, P.O. Box 2008, Oak Ridge, TN 37831-6269.

39-48. Office of Scientific and Technical Information, P.O. Box 62, Oak Ridge, TN 37831.

49. L. F. Blankner, Energy Research and Development, DOE-OR, P.O. Box 2008, Oak Ridge, TN 37831-6269.

50. L. L. Carter, Westinghouse-Hanford Company, 400 Area Trailer 1, P.O. Box 1970 , Richland WA 99352.

51. R. K. Disney, Westinghouse Electric Company, P.O. Box 158, Madison, PA 15663.

52. P. B. Hemmig, Safety and Physics Branch, Office of Technology Support Programs, DOE-Washington, Washington, DC 20585.

53. Dr. James E. Leiss, Route 2, Box 142C, Broadway, VA 22815.

54. Prof. Neville Moray, Department of Mechanical and Industrial Engineering, 1206 West Green Street, Urbana, IL 61801.

55. Prof. Mary F. Wheeler, Department of Mathematical Sciences, Rice University, P.O. Box 1892, Houston, TX 77251.

56. K. Takahashi, Power Reactor and Nuclear Fuel Development Corporation, Sankaido Building, 9-13, 1-Chome, Miato-Ku, Tokyo, Japan.

57. T. Yagi, Power Reactor and Nuclear Fuel Development Corporation-Washington, Suite 715, 2600 Virginia Avenue NW, Washington, DC 20037. 
58. K. Chatani, Power Reactor and Nuclear Fuel Development Corporation, 4002 Narita-Cho, O-Arai-Machi, Ibaraki-Ken, 311-13, Japan.

59-131. Given distribution as shown in DOE/OSTI-4500-R75, LMFBR-Physics: 